\title{
Trilobites of the
}

Upper Cambrian

Dunderberg Shale

Eureka District, Nevada

By ALLISON R. PALMER

SHORTER CONTRIBUTIONS TO GENERAL GEOLOGY

GEOLOGICAL SURVEY PROFESSIONAL PAPER $334-\mathrm{C}$

Fifty-three species of trilobites representing

32 genera are described and illustrated

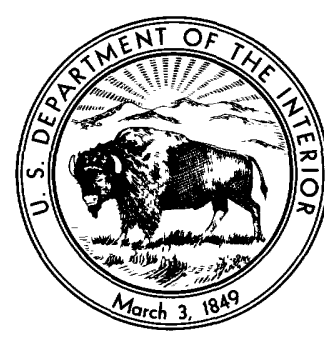

UNITED STATES GOVERNMENT PRINTING OFFICE, WASHINGTON : 1960 
UNITED STATES DEPARTMENT OF THE INTERIOR

FRED A. SEATON, Secretary

\section{GEOLOGIGAL SURVEY}

Thomas B. Nolan, Director 


\section{CONTENTS}

Abstract..............

Introduction.

Acknowledgments

Stratigraphy -

Taxonomic procedure

Terminology

Hypostome morphology and identification.

Systematic paleontology

Agnostidea

Angostidae

Pseudagnostus

Homagnostus . . . . . . . .

Phalacroma

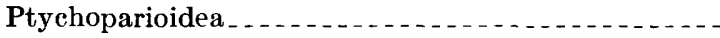

Elviniidae. . . . . .

Dunderbergia

Elburgia

Elvinia $\ldots \ldots \ldots \ldots \ldots$

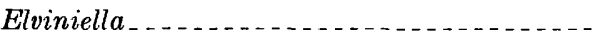

Irvingella

Housiidae

Housia

Parahousia

Prehousia.

Olenidae.

Olenus(?)
Page | Systematic paleontology-Continued Ptychoparioidea-Continued

Aphelaspidinae -

Litocephalus..................... 81

Taenora....................... 83

Pterocephaliinae...... 84

Cernuolimbus................... 84

Pterocephalia.................... 86

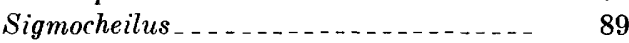

Ptychoparioidea unassigned _._.

Anechocephalus......................... 92

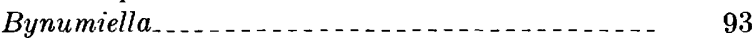

Bynumina.............................. 93

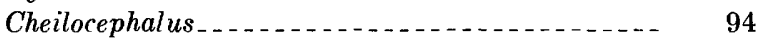

Dokimocephalus......... 95

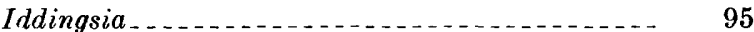

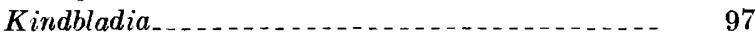

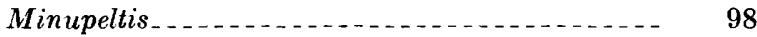

Morosa

Oligometopus...................... 100

Pinctus_......... 100

Pseudosaratogia

Genus and species undetermined 1......... 101

Genus and species undetermined 2 . . . . . . 102

Genus and species undetermined $3 \ldots \ldots \ldots 2$

Locality information . .

References cited

Index $\ldots \ldots$.

\section{ILLUSTRATIONS}

Plate 4. Agnostidae and Elviniidae.

[Plates 4-11 follow page 110]

5. Elviniidae.

6. Elviniidae and Olenidae.

7. Housiidae and Aphelaspidinae.

8. Pterocephaliinae, Aphelaspidinae, and Anechocephalus.

9. Pterocephaliinae.

10. Pterocephaliinae and unassigned genera.

11. Unassigned genera and Hypostomes.

Figtre 5. Map showing relations of the Eureka district to other localities in the Great Basin with Dunderberg faunas.....-

6. Map showing location of measured section through Dunderberg shale

7. Ranges of trilobites in the Dunderberg shale

8. Comparison of the ventral courses of the cephalic sutures in some Late Cambrian trilobites. A, Pterocephalia.

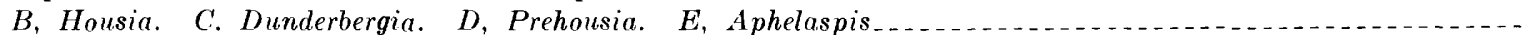

9. Dunderbergia polybothra n. sp_.

10. Elburgia quinnensis (Resser)

11. Elvinia roemeri (Shumard)

12. Housia ovata n. $\mathrm{sp}_{-} \ldots$

13. Parahousia constricta n. sp

14. Prehousia alata n. sp _..

15. Olenus(?) wilsoni Henningsmoen

16. Litocephalus bilohatus (Hall and Whitfield

17. Taenora expansa $\mathrm{n}$. $\mathrm{sp}_{\ldots} \ldots$

18. Cernuolimbus nrygmatos n. sp

19. Pterocephalia sanctisabae Roemer

20. Sigmocheilus serratus n. sp _...

21. Bynumiella? acuminata n. sp $\ldots$

22. Morosa longispina $\mathrm{n}$. $\mathrm{sp}$ 



\title{
SHORTER CONTRIBUTIONS TO GENERAL GEOLOGY
}

\section{TRILOBITES OF THE UPPER GAMBRIAN DUNDERBERG SHALE, EUREKA DISTRICT, NEVA DA}

\author{
By Allison R. Palmer
}

\begin{abstract}
The Dunderberg shale in the Eureka district is the northwesternmost expression of a relatively thin nonresistant unit (100-300 $\mathrm{ft}$ thick) of interbedded shale and fossiliferous limestone of Late Cambrian age lying between generally less fossiliferous and more resistant carbonate units in southeastern Nevada and adjacent parts of Utah and California. Five local lithic units, designated by letter and beginning at the base with a shale unit (A), are recognized within the Dunderberg shale. Overlying units alternate in dominance between limestone and shale. All but the upper unit (E) contain thin fossiliferous limestones bearing generally distinctive trilobite assemblages. Ranges of many common species are sufficiently restricted so that isolated collections from structurally disrupted areas within the Eureka district can be placed within 20 to 40 feet of their original stratigraphic position within the upper or lower parts of the Dunderberg shale. The fauna of units A-C belongs to the upper half of the Dunderbergia zone of late Dresbach age. The fauna of unit $D$ correlates with the basal part of the Elvinia zone of early Franconia age. The presence of Homagnostus obesus (Belt) and Olenus? wilsoni Henningsmoen in units $\mathbf{A}$ and $\mathbf{B}$ indicates a correlation of these beds with the Olenus and $H$. obesus zone in the early Late Cambrian section of the Scandinavian region.

Fifty-three species representing 32 genera are described. The following new taxa are named: Subfamily Aphelaspidinae (of the family Pterocephaliidae); Genera Elburgia, Elviniella, Prehousia, Parahousia, Cernuolimbus, Sigmocheilus, Taenora, Minupeltis, Morosa, Anechocephalus; and species, Dunderbergia bigranulosa, D. polybothra, Elviniella laevis, Prehousia semicircularis, P. alata, Parahousia constricta, Housia ovata, Cernuolimbus semigranulosus, C. orygmatos, C. depressus, Pterocephalia concava, P. elongata, Litocephalus verruculapeza, L. granulomarginatus, Taenora expansa, Sigmocheilus serratus, Minupeltis ronservator, Morosa longispina, Bynumiella? acuminata, Anechocephalus trigranulatus, Pseudosaratogia leptogranulata, and $P$. abnormis. Evidence is shown that primary species characteristics are to be found in the external ornament of the exoskeleton. Genera are composed of species sharing nearly conmon shape but differing consistently in characteristics such as external ornament. Emphasis in family groupings is placed on structure of the glabella, frontal area, and pleural parts of the pygidium. Application and elaboration of the principles for grouping trilobites into genera and families are illustrated particularly with regard to the families Elviniidae, Housiidae, and Pterocephaliidae.
\end{abstract}

\section{INTRODUCTION}

The Dunderberg shale is a relatively nonresistant unit of interbedded shale and fossiliferous limestone; its type locality is in the Eureka district, Nevada. In this district, the Dunderberg lies conformably on the more resistant Hamburg dolomite and is overlain, also conformably, by the generally cherty Catlin meriber of the Windfall formation (Nolan and others, 1956). A similar fossiliferous nonresistant unit of interbedded limestone and shale with approximately the same relation to adjacent carbonate units is present in almost every Upper Cambrian sequence of rocks south of the 40th parallel in southern Nevada and adjacent parts of Utah and California (Palmer, 1956b). Despite the apparent extensive geographic distribution of the Dunderberg shale or correlative lithic units (over 250,000 square miles) (fig. 5) and the generally fossiliferous nature of the Dunderberg, less than 30 species of trilobites in its large fauna have been described.

The earliest descriptions of trilobites from the Dunderberg shale are by Hall and Whitfield (1877) and Walcott (1884). Since these publications, only occasional references have been made to Dunderberg trilobites principally as nomenclatural changes or brief descriptions of new forms in large regional faunal papers (Walcott, 1916, 1924, 1925; Resser, 1935, 1936, 1937, 1942; Palmer, 1955). The purpose of this paper is to describe the trilobites of the Dunderberg shale in its type area and to document as precisely as possible the stratigraphic distribution of the described fossils within the unit.

The bulk of the material examined during this study came from collections by C. D. Walcott, and geologists of the 40th parallel survey in the late 1800's; collections by the late Josiah Bridge and G. A. Cooper in 1939; and collections by the writer in 1951 and 1957 .

The collections in 1951 and $195 \pi$ were obtained from the section in Windfall Canyon chosen by Nolan and others (1957, p. 19) as the most complete and unbroken section of the Dunderberg shale in the Eureka district (fig. 6). Each collection was obtained from a single bed and located with respect to stratigrephic distance from the base of the formation with a steel tape. Descriptions of localities for all the collections referred to in the text are given on pages $102,103$. 


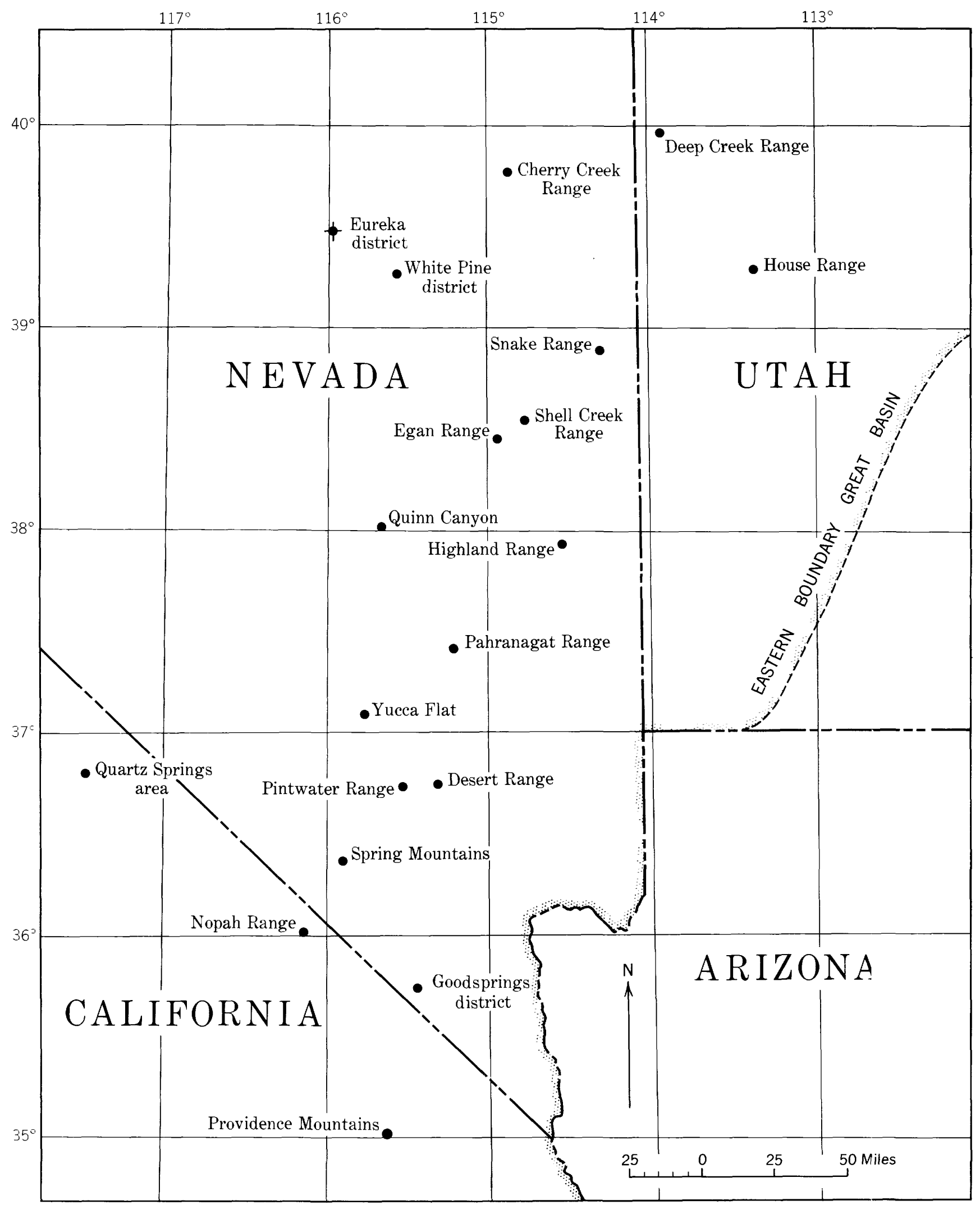

Figure 5.-Map showing relations of the Eureka district to other localities in the Great Basin with Dunderberg faunas. 


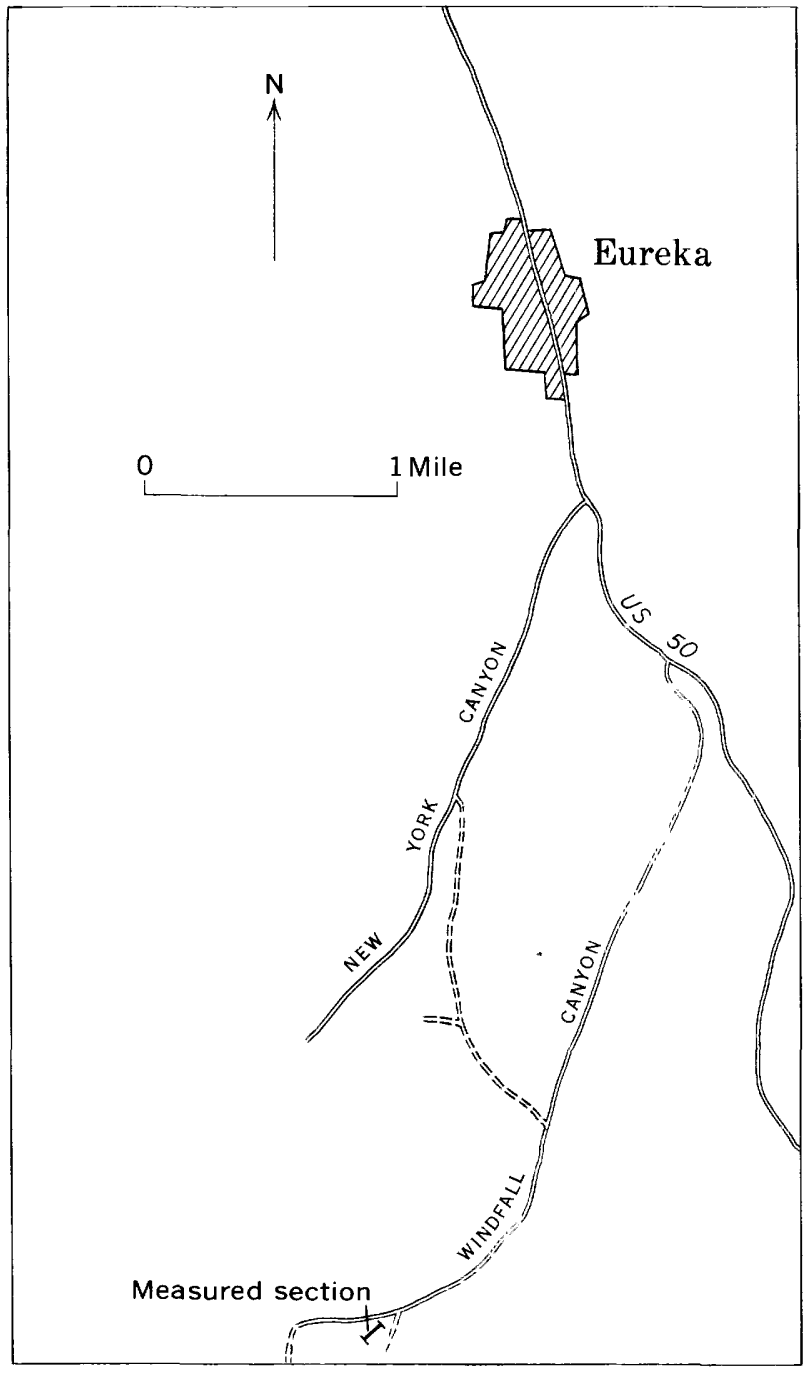

FIGURE 6.-Map showing location of measured section through Dunderberg shale.

The collections from the measured section were studied first so that association of species and stratigraphic ranges of species could be correctly determined. Supplemental material for morphologic study was obtained from the collections by Bridge and Cooper. Identification of taxa that were not new was determined by comparison with the types in the U.S. National Museum collections.

Parts of each of the Bridge and Cooper and later collections were dissolved in formic acid to obtain insoluble residues. Most of them contain abundant phosphatic brachiopods. Occasionally a few silicified small trilobites were also recovered. The only silicified specimen illustrated is the free cheek of Bymumiella? acuminata n. sp.

The other specimens illustrated and studied were prepared by hand. Most of the matrix surrounding each specimen was first ground away with a thin diamond-bearing blade in a dental drill. The remainder of the matrix was removed using a Burgess Vibro- tool fitted with a chuck for holding a needle. This sufficiently improved the efficiency of preparation so that only occasionally was final cleaning by hand with a sharpened needle necessary.

All the specimens were whitened for study with a light coating of magnesium oxide obtained by burning a short length $(3 / 4 \mathrm{in}$.) of magnesium ribbon. Generally it is not possible to determine properly the characteristics of a specimen without this coating, especially in groups where surface texture is an important taxonomic feature.

Drawings were prepared for all species represented by cranidia and free cheeks. Thoracic segments and pygidia were included where known. Specimens selected for drawing were properly oriented under a binocular microscope fitted with an eyepiece containing an ocular grid. The image was transferred from the ocular grid to graph paper. A projector that could enlarge or reduce drawings by several diameters proved invaluable for reconstruction of trilobite cephala, because it is generally not possible to find a cranidium and free cheek of the same instar that are sufficiently well preserved for illustration.

All the photographs were prepared using standard photographic techniques. Specimens were coated with ammonium chloride for photography because depth of coat is easier to control for this material than it is for the magnesium oxide used for study. Most of the original Hall and Whitfield and Walcott types are illustrated here by stereophotographs, as are holot."pes or selected paratypes of all new species.

\section{ACKNOWLEDGMENTS}

Assistance in the field, in addition to that given by U.S. Geological Survey personnel, was rendered by Dr. A. B. Shaw, of the University of Wyoming, in the summer of 1951. All photographs of fossils were prepared by N. W. Shupe, of the U.S. Geological Survey. Dr. Hans Frebold, head of the Division of Stratigraphic Paleontology, Geological Survey of Canada, loaned for comparison, types of the Upper Cambrian trilobites from British Columbia described by Kobayashi (1938).

\section{STRATIGRAPHY}

The Inuderberg shale in the Eureka district is composed of interbedded limestone and shale. It can be divided roughly into five lithic units alternating in dominance between one or the other of these rock types (Nolan and others, 1956. p. 19). The limestone is generally thin to medium bedded, and many of the thin beds contain abundant remains of trilobites and phosphatic brachiopods. No fossils have been found in the shale. Lithic units with their thicknesses are designated here by letter, beginning with the oldest: 
Unit $\mathrm{A}$, about 35 feet, dominantly shale; unit $\mathrm{B}$, about 45 feet, dominantly limestone; unit $\mathrm{C}$, about 140 feet, dominantly shale; unit $\mathrm{D}$, about 35 feet, dominantly limestone; and unit $\mathrm{E}$, about 10 feet, dominantly shale.

Trilobites are most abundant in unit B and in limestone beds of units $A$ and $C$. Unit D is only locally fossiliferous, and no fossils are known from unit $\mathrm{E}$.

The fauna of unit $\mathrm{A}$ is characterized by relatively large numbers of specimens of Dunderbergia bigranulosa n. sp. Cernuolimbus orygmatos n. sp. is common in a limestone bed near the top of the unit but is also common in a collection from the basal part of unit B.

Unit B contains over half of the described species of the Dunderberg fauna. Its most distinctive constituent is Morosa longispina n. sp. Relatively numerous specimens of species of Dunderbergia, Litocephalus, and Pterocephalia also characterize the fauna of this unit. Homagnostus tumidosus (Hall and Whitfield) is common, but ranges upward through the rest of the Dunderberg and into the overlying Windfall formation.

Few of the thin limestones of unit $\mathrm{C}$ are fossiliferous. The limestones of the upper part of the unit are characterized by sigmorheilus serratus n. sp., Housia ouata n. sp., and Parahousia constrictu n. sp., in association with the long-ranging species Dunderbergia nitida (Hall and Whitfield). Collections from the lower part of unit $C$ seem to be transitional to the fauna of unit $B$. The assignment of a collection to unit $C$ can be confirmed, however, by preparing an insoluble residue. Limestones of unit $\mathrm{C}$ generally yield shells of the acrotretid brachiopod Linnarssonella, whereas unit B lacks brachiopods of this genus and generally has a large and raried assortment of other acrotretid brachiopods.

The fauna of unit D is not so well known as those of the older units. Only one small collection was obtained from this unit in the measured section. This collection contained Kindbladia affinis (Walcott). Collections by the early surveys of the Eureka district containing $K$. affinis in association with species of Ireingella (Parairvingella), Bymumina globosa (Walcott), and Iddingsiu robustu (Walcott) probably came from this unit because none of these species are known from unit $\mathrm{C}$ or from the basal beds of the overlying Windfall formation.

All the trilobites in mits A-C, and the majority of the trilobites described in this paper, represent the fauna of the recently established Tunderbergia zone (Lochman and Wilson, 1958, p. 333). This zone was defined to include the faunas, formerly assigned to the post-Apheluspis zone (Palmer, 195+), that occur between the well-known and widespread Aphelaspis and Elvinia faunas in the Great Basin. central Texas, and perhaps in Missouri. As with most Upper Cambrian trilobite zones, individual genera, including Iunderbergia, may range above or below the zonal limits, and precise boundaries between adjacent zones cannot always be drawn.

In the Dunderberg shale, the boundary between the Dunderbergia zone and the overlying Elwinia zone is approximately at the top of unit $\mathrm{C}$. The trilobites from unit D represent genera that are known from the Elcinia fauna at many localities in the western half of the United States. Most of the trilolites from unit $C$ are known only from the Great Basin in beds older than those with Elvinia.

The lower limit of the Dunderbergia. zone is not demonstrable in the Eureka district. Correlation of the Dunderberg shale with fossiliferous Upper Cambrian units of eastern Nevada and western Utah indicates that the Dunderberg fauna reprasents perhaps only the upper half of the fauna of the Dunderbergia zone. The lower fauna of this zone is still largely undescribed but is probably represented in the Lincoln Peak formation in the Snake Range, Nev., and the Orr formation in the House Rango, Utah.

Ranges of the trilobites in the measured section of the Dunderberg shale in the Eureka district are shown in figure 7 .

Fossiliferous units partly or wholly equivalent in age to the Dunderberg shale are known in the Great Basin (fig. 5) from the basal parts of the Nopah formation in the Quartz Spring area (McAllister, 1952) and the Nopah Range, Calif.; the basal Cornfield Springs formation in the Providence Mountains, Calif., and in the Goodsprings district, Nevada (Palmer and Hazzard, 1956); the Dunderberg shale on the east side of Yucca Flat, Nev. (Hibbard and Johnson, 1957); unnamed formations in the Desert Range, Spring Mountains, and Pintwater Range, the east side of the Highland Range, the Pahranagat, Egan, Shell Creek, and Cherry Creek Ranges, and the White Pine district, Nevada; the Johns Wash limestone and Corset Spring shale in the Snake Range, Nev. (Drewes and Palmer, 1957); the Hicks formation in the Deep Creek Range and the Orr formation in the House Range, Utah.

Outsicle the Great Basin, the upper part of the Lion Mountain sandstone member of the Riley formation in central Texas and part of the Daris formation in Missouri have some trilobites in common with the fauna of the Dunderberg shale.

The occurrence of Homugnostus obesus (Belt) and an olenid in the lower part of the Dunderberg shale and species of Irvingella (Parairvingella) in the upper part of the shale indicate a probible correlation of the formation with zone II (Olenus; $H$. obesus) 
(Henningsmoen, 1957) of the Upper Cambrian section of the Baltic region, where $H$. obesus and $I$. $(P$. suecica Westergard have the same relative positions.

\section{TAXONOMIC PROCEDURE}

Classification of trilobites into species, genera, and particularly into higher taxonomic categories requires careful attention to two independent categories of facts: exoskeleton morphology and geologic occurrence. A lasting classification can be derived only by proper interpretation of the relative taxonomic significance of the observed morphologic features, the range of the trilobite in time and space, and the environments inhabited by the trilobite. s'pecies characters.-The subtleties of specific differences and the importance of careful examination of all possible parts in determining species characteristics are perhaps best exemplified by the species of Dunderbergia, Cernuolimbus, and Litocephalus.

Large collections from 7 thin fossiliferous limestone beds in the lower 80 feet of the Dunderberg shale in the measured section averaged nearly 40 specimens referable to Dunderbergia. Comparison of these specimens shows that shape alone does not provide a satisfactory means for discrimination of the trilobites represented in the successive collections. Examination of the external surfaces of all parts shows, however, that for any one collection the nature of the

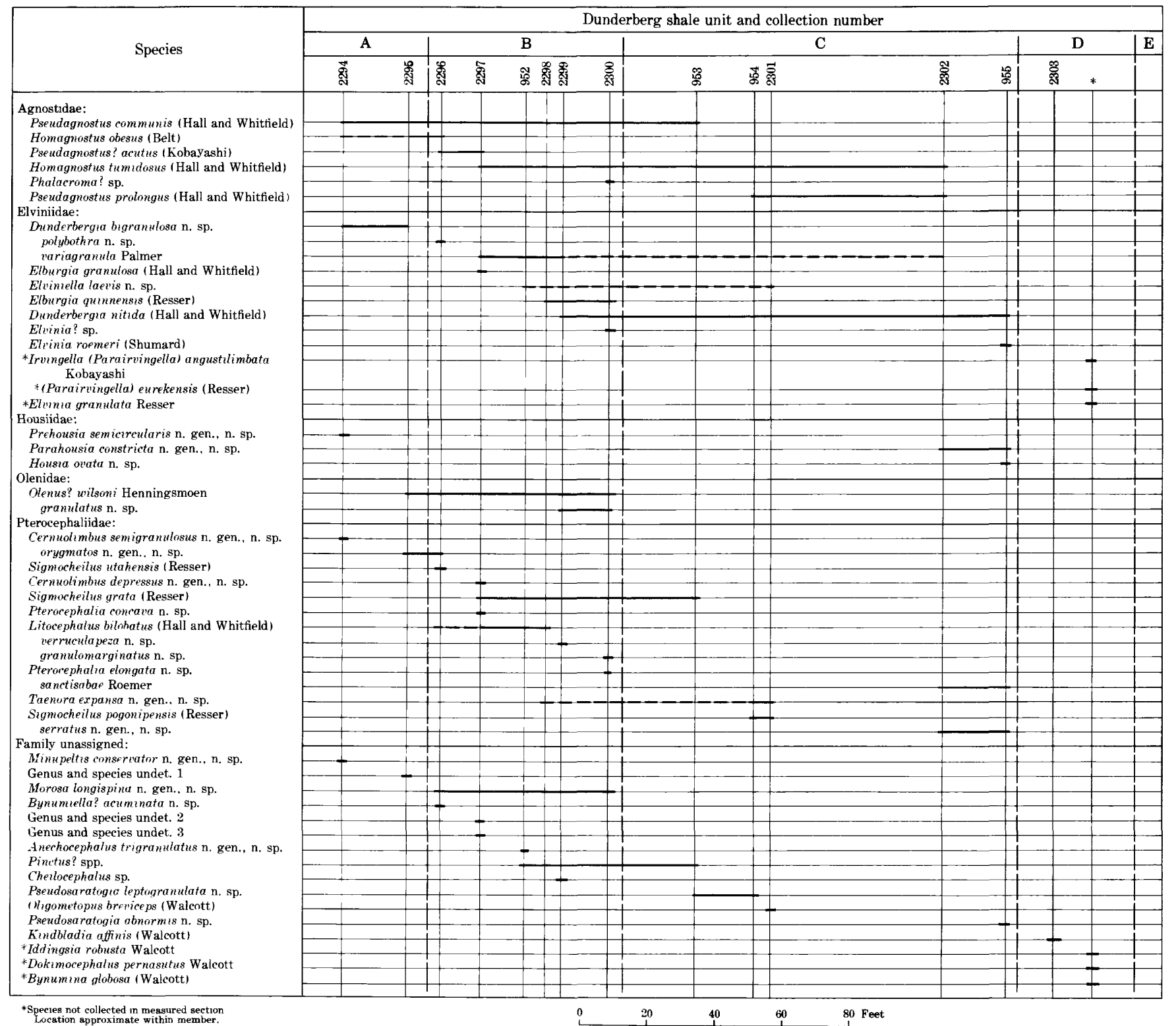

Fistre 7.--Ranges of trilobites in the Dunderberg shale. Collections located acerording to distances measured hy steel tape fron base of Dunderberg shale. Member hundaries approximate. 
surface is virtually constant. Thus, all specimens of Dunderbergia in collection 2295-CO that retain their exoskeleton (most of the 99 identified specimens) have a granular ornament: cranidia have fine granules on the border and glabella and faint coarse scattered granules on the brim; free cheeks have fine granules on the border and faint coarse scattered granules on the ocular platform, and pygidia have fine granules on all parts. In collection 2296-CO, only 10 feet higher in the same section, all specimens of Dunderbergia retaining their exoskeleton (most of the 58 identified specimens) have a distinct pitted ornament on nearly all surfaces of all parts. If the exoskeleton surface in these 2 collections was not known, it would be nearly impossible to determine either by inspection or by statistical analysis that the trilobites represent 2 different taxa (cf. pl. 5, figs. 1 and $14 ; 13$ and 19). For the reasons given above, the specimens of Dunderbergia in collections 2295- $\mathrm{CO}$ and 2296-CO are here considered to represent populations of two distinct species. Analagous relationships in Cernuotimbus and Litorephalus are discussed below.

Cernuolimbus is represented by 30 specimens in USGS collection 2294-CO and by over 100 specimens in USGS collection 2295-CO, 18 feet higher in the measured section. Most of the specimens retain some or all of their exoskeleton. In collection 2294-CO all specimens with exoskeleton preserved bear fine granules: on the cranidium they are on the top of the glabella and on the palpebral lobes; on the free cheek they are on the genal spines; and on the pygidium they are present, though faint, over most of the surface. In collection 2295-CO, all parts with exoskeleton preserved are coarsely pitted and, in addition, each axial ring on the pygidium has a pair of coarse granules. Although there are slight differences in shape also, that is, shape of anterior margin and width of the border of the free cheek, the feature that emphasizes the specific difference of the two assemblages is the surface ornament of the exoskeleton (cf. pl. 8, figs. 1 and 5:2 and 6).

A third example showing the primary importance of surface ornament as a species character is given by Litorephalus. Although specimens are not so numerous as in the preceding 2 genera, 3 successive collections, USGS collections $2297-\mathrm{CO}-2299-\mathrm{CO}$ contain specimens that are distinguishable primarily by the ornament on the border of the cranidium. L. bilobatus (Hall and Whitfield) has a smooth cranidial border, $L$. rermuculapeza n. sp. has a cranidial border with scattered coarse granules, and L. gramulomarginutus $n$. sp. has a cranidial border covered with fine close-spaced granules. Discrimination of the species on shape alone is considerably more difficult and less reliable (cf. pl. 8, figs. 12 and $13 ; 14$ and 17 ).
In Dunderbergia, Cernuotimbus, and Litocephalus, therefore, primary definitive species characteristics are to be found by examination of the surface of the exoskeleton and not necessarily by comparison of shape. Absence of consistent difference in share between all parts of two assemblages should not be used as a criterion for conspecificity without knowledge of the exoskeleton surface. This does not deny the taxonomic significance of shape, however. Consistent differences in shape of any part between two assemblages having otherwise similar exoskeletons probably also indicate a real taxonomic difference between the assemblages.

Discrimination of the 51 species here described is based on the principles outlined above. Diagnostic characteristics of those species that are indicated to be moderately common, common or abundant (that is, 25-50, 50-100, or more than 100 identified specimens) will probably not be significantly modified by study of new material from other areas. Diagnostic criteria of species indicated to be moderately rare, rare or very rare (that is, $10-25,2-10$, and single identified specimens) may be modified by later work.

Generic groupings.-Grouping of specimens together into species can be done on a reasonably objective basis as outlined above. Grouping of these species into genera is considerably more subjective. The principles used here are best illustrated by examination of the species assigned to Dunderbergia and to Litocephalus (pl. $4,5,7,8$ ). In both genera, the species share a nearly common shape in all of their parts. Very likely, the living trilobites swimming or crawling in the sea would not have been noticeably different until their surfaces were examined with a lens or microscope (excluding, of course, the probability that the soft parts or color would provide additional characters). The fact that trilobites with roughly the same shape differ specifically in their surface ornament has been of primary importance in establishing genera. Trilobites with similar shapes, differing only in details such as ornament, or perhaps of shape of only one part, are here considered congeneric. Trilobites having consistent differences particularly in their cranidia and especially in shape or outline of the border, frontal area or glabella, are here considered to represent different genera. Differences observed on other parts of the trilobite are generally considered to be of secondary importance. As with the species, those genera that have a strikingly distinct shape, or those that are represented by moderately common to abundant material of more than one species, are the least likely to be modified by study of new material.

s'uprageneric groupings.-Suprageneric groupings are necessarily generalizations, outlining, in the considered opinion of a specialist, the presumed relation- 
ships between genera. As successive generations of specialists learn more about the morphology of fossils and their stratigraphic and geographic distribution, the generalizations of the preceding generation require refinement. Eventually a reasonable stability in the content and characteristics of suprageneric groups is attained. Comparisons of the family classifications recently discussed by Hupé $(1953,1955)$ and Lochman $(1953,1956)$ indicate that this stage has not yet been reached by students of Cambrian trilobites.

In this paper, trilobites are grouped into suprageneric categories of morphologically similar forms on the premise that such morphologic similarity between unrelated trilobites is unlikely in a single sedimentary basin during a period of time when there was little, if any, significant change in environmental conditions or paleogeography. The stratigraphic and geographic continuities of faunas are particularly important in such an initial compilation because they are the only criteria other than morphology for determining probable relationships between trilobites. Without knowledge of occurrence of two trilobites, it is difficult to evaluate properly the taxonomic significance of their apparently similar structures.

Once suprageneric categories are defined using the criteria just discussed, it is possible to evaluate intelligently the degree of taxonomic relationship between apparently similar trilobite genera that are isolated stratigraphically by faunal discontinuities or geographically by existence in different basins of sedimentation.

The trilobite genera of the Dunderberg shale developed in an area of nearly continuous sedimentation and relatively little environmental change through a restricted part of Late Cambrian time. There are no striking "faunal breaks." Thus, many of these genera are probably related, and the relationships are most likely to be expressed by shared structural features of the exoskeleton. Examples of the application of the principles outlined above to the Dunderberg trilobite fauna are illustrated particularly in the discussions of the Elviniidae (p. 6t) and the Pterocephaliidae (p. 80).

\section{TERMINOLOGY}

The descriptive terminology used in this paper for dorsal features of the trilobites is that proposed by Howell and others (1947) with the additions and modifications given below. Glabella includes the occipital furrow and occipital ring. Frontal area (Nelson, 1951, p. 771) refers to that part of the cranidium in front of the glabella. Axial lobe is the generally raised axial part of the exoskeleton; on the pygidium it may be divided into axial rings bounded by ring furrows (Whittington and Evitt, 1954, p. 14). Pleural ribs refer to generally transverse poorly de- fined raised ridges that cross the pleural platform and, on some trilobites, the border of the pygidium.

Descriptive terminology for the hypostome is that proposed by Warburg (1925).

Sagittal, exsagittal, and transverse refer to directions in vertical planes in the axial line, parallel to the axial line, or at right angles to the axial line, respectively (Whittington and Evitt, 1954, p. 12). Measurements in the sagittal plane (along chords) are: length of border, from the anterior margin to the middle of the marginal furrow; length of brim, from the middle of the marginal furrow to the middle of the dorsal furrow in front of the glabella; length of glat olla, excluding occipital ring, from the middle of the dorsal furrow in front of the glabela to the middle of the occipital furrow. The occipital ring is not included in measurements of the length of the glabella unless so indicated because it is so commonly broken on specimens preserved in limestone. Measurements in transverse planes are: width of palpebral lobes, from the outer edge of the palpebral lobe to the middle of the palpebral furrow at about the midlength of the palpebral lobe; width of cheek, from the middle of the palpebral furrow to the middle of the dorsal furrow on a line through the midlengths of the palpebral lobes; and basal glabellar width between the dorsal furrows just anterior to the occipital furrow. Length of the palpebral lobe is measured along a chord between the points of maximum indentation of the sides of the cranidium above the eyes by the facial sutures.

Depressed, downsloping, horizontal, upsloping, and elevated refer to positions of the border, brim and fixed cheeks on the cranidium, and the border and pleural platforms of the pygidium with respect to a horizontal plane passing through the dorsal furrow, as defined by Lochman (1947, p. 60).

Convex, concave, and flat refer to degrees of curvature of various parts of the trilobite as seen in transverse or sagittal cross section. Degree of convexity or concavity is indicated as gentle, moderate, or strong if the arc of the part described subtends an angle of less than $90^{\circ}, 90^{\circ}$ to $180^{\circ}$, or more than $180^{\circ}$, respectively (Whittington and Evitt, 1954, p. 12). Convexity or concavity of the brim, border and occipital ring, and longitudinal convexity of the cranidium, glabella, pygidium, and hypostome are described as seen in saggital cross section. Convexity of the fixed cheeks and transverse convexity of the cranidium, glabella, hypostome, and pygidium are described as seen in transverse cross sections through the midlengths of the palpebral lobes, glabella, and hypostome and through the anterior margin of the pygicium, respectively.

Ornament of the external parts of the exoskelton may be granular, with granules all of one size-Elburgia granalosa (Hall and Whitfield), pl. 6, fig. 12-or 
with two or more sizes (Dunderbergia bigranulosa n. sp., pl. 5, fig. 13); smooth or pitted (pl. 5, fig. 14; pl. 8, fig. 5). It is generally absent from all furrows. When present, it may be evenly distributed over most of the surface as in Dunderbergia polybothra n. sp. or restricted to the border, brim, or tops of the axial structures. Details of external ornament and its distribution are consistent between specimens of most species, and this is often a characteristic of prime importance for specific distinction.

Surfaces of molds may have coarse granules corresponding to those of the external parts of the exoskeleton. Fine-granular ornament is generally lacking. Molds of many species with smooth or fine-granular external ornament are finely pitted.

Terrace lines are present on the doublures of all specimens, on part, or all, of the cephalic and pygidial borders, and on the tips of the thoracic segments of some species, particularly in the Pterocephaliinae.

\section{HYPOSTOME MORPHOLOGY AND IDENTIFICATION}

Hypostomes are rare in the collections from the Dunderberg shale. As a result, the few specimens that have been obtained cannot generally be assigned to a particular species. Nevertheless, hypostomes of at least five species are recognizable. All of these share the following characteristics: Moderate to strong transverse and longitudinal convexity, elongate quadrangular outline with rounded posterior margin, moderately well defined lateral furrows with a distinct oval or circular depression adjacent to the posterior lobe of the middle body, distinct terrace lines on the lateral and posterior margins, and prominent dorsally directed posterior wings. Differences are most apparent in presence or absence of a distinct posterior border and in details of the lateral furrow and surface ornament.

Hypostome A (pl. 11, fig. 12) is characterized by having a distinct posterior border and faint pits on the posterior part of the anterior lobe of the middle body. The lateral furrow is deep adjacent to the middle part of the anterior lobe of the middle body. Two hypostomes of this type from USGS collection 2302-CO are present; the largest is $4 \mathrm{~mm}$ long. Sigmocheilus serratus $\mathrm{n}$. $\mathrm{sp}$. and Dunderbergia nitida (Hall and Whitfield) are the only two common trilobites in that collection that were large enough to have borne this hypostome.

Hypostome B (pl. 11, fig. 7 ) is characterized by a distinct but narrow posterior border and a faint roughening of the axial part of the anterior lobe of the middle body. This type is represented by 1 specimen, $5.5 \mathrm{~mm}$ long, from USGS collection 2295-CO. Dunderbergia bigranulosa n. sp. and Cernuolimbus orygmatos n. sp. are the only two common large trilobites in this collection.

Hypostome C (pl. 11, fig. 4) is characterized by absence of a distinct posterior border, shallow lateral furrows, low scattered granules on the surface posterior to the middle furrow, and a tendency towards a subangular outline to the posterolateral and posterior margins. Minute pits are on the posterior part of the anterior lobe of the middle body. Specimens of this type are present in USGS collections $2294-\mathrm{CO}$ and 2295-CO. The largest specimen is $5 \mathrm{~mm}$ long. Dunderbergia bigranulosa $\mathrm{n}$. $\mathrm{sp}$. or species of Cernuolimbus are the only common large trilobites in these collections.

Hypostome D (pl. 11, fig. 9) is characterized by absence of a distinct posterior border, shallow lateral furrows, and an evenly curved posterior margin. The only ornament is minute, barely visible pits on the posterior part of the anterior lobe of the middle body. Specimens of this type come from USGS collections 2300-CO and 2301-CO. The largest specimen is $\mathbf{5 . 5}$ $\mathrm{mm}$ long. Pterocephalia elongata $\mathrm{n}$. sp. from collection 2300-CO, sigmocheilus pogonipensis (Resser) from collection 2301-CO, and Dunderbergia nitida (Hall and Whitfield) - which occurs in both collections-are the common large trilobites most likely to have borne the hypostomes of this type.

Hypostome E (pl. 11, fig. 8) is cheracterized by absence of a distinct posterior border, shallow lateral furrows, and distinct pits on the posterior part of the anterior lobe of the middle body and or the posterior lobe of the middle body. This hypostome, which is $5 \mathrm{~mm}$ long, comes from USGS collection 2296-CO where the only common large trilobite is Dunderbergia polybothra n. sp.

Each of the hypostome types, except type E, is associated with common species of Pterocephaliidae and Elviniidae. Whittington and Evitt (1؟54, p. 20, 21) have indicated that hypostomes show relationships at the family level. Hypostome type $\mathrm{E}$ is certainly assignable to a species of the Elviniidae. This hypostome shares two common characters with hypostome types $\mathrm{C}$ and $\mathrm{D}$ : absence of a distinct pcsterior border and presence of pits anterior to the middle furrow on the anterior lobe of the middle body. Each of these hypostome types occurs in a collection with a common species of Dunderbergia, and the ornament posterior to the middle furrow corresponds to the ornament on the glabella of the Dunderbergia species. Thus, it seems possible that these are Dunderbergia hypostomes. They differ from hypostome types $\mathrm{A}$ and $\mathrm{B}$ by lacking a distinct posterior border, and this may be the character that distinguishes hypostomes of the Elviniidae from those of the Pterocephaliidae. However, application to types $A$ and $B$ of this hypothesis 
and a corollary, that ornament of posterior to the middle furrow corresponds to ornament of the glabella, casts some doubt on its correctness. Type A should have a granular ornament posterior to the middle furrow, and type B should have a distinct pitted ornament-but this is not true. There is no guarantee, however, that the hypostomes are parts of the common species in the collections. Until more hypostomes are known from more collections with only one common species, criteria for correct specific, generic, and family assignment of individual specimens must remain uncertain.

\section{SYSTEMATIC PALEONTOLOGY}

\section{Superfamily AGNOSTIDEA Richter}

Family AGNOSTIDAE McCoy

The Agnostidae of the Dunderberg shale have for the most part been described in an earlier paper (Palmer, 1955). The information given below supplements and modifies the information presented at that time.

\section{Subfamily PSEUDAGNOSTINAE Whitehouse}

\section{Genus PSEUDAGNOSTUS Jaekel}

Pseudagnostus Jaekel, 1909, p. 400; Kobayashi, 1935, p. 107; 1937 , p. 451 ; 1939 , p. 157 ; Shimer and Shrock, 1944, p. 601 ; Shaw, 1951, p. 112; Palmer, 1954, p. 719; 1955, p. 93.

Rhapatagnostus Whitehouse, 1936, p. 97.

Plethagnostus Clark, 1923, p. 124; 1924, p. 16.

Type species.-Agnostus cyclopyge Tullberg, 1880, p. 26.

Diagnosis.-Cephalon with trilobed glabella and a preglabellar median furrow. Basal glabellar lobes simple.

Pygidium with anterior third of axial lobe defined by subparallel dorsal furrows; pseudolobe moderately well to poorly defined by accessory furrows that may disappear posterolaterally so that pseudolobe merges with pleural lobes. Marginal spines present or absent.

\section{Pseudagnostus communis (Hall and Whitfield)}

\section{Plate 4 , figures 3,4}

Agnostus communis Hall and Whitfield, 187t, p. 228, pl. 1, figs. 28, 29.

Agnostus neon Hall and Whitfield, 1877, p. 229, pl. 1, figs. 26 , 27.

Pseudagnostus communis (Hall and Whitfield). Palmer, 1954, p. 720 , pl. 76 , figs. $1-3 ; 1955$, p. 94 , pl. 19 , figs. $16,19-21$; pl. 20, figs. $4-11,14$.

Diaynosis. - Specimens of Preudagnostus with glabella and first glabellar lobe moderately well defined on external surface of cephalon. Preglabellar median furrow shallow. All furrows deeper on surface of mold.
Pygidium with anterior third of axial lobe well defined. Shallow accessory furrows generally only apparent along anterolateral parts of pseudolobe. Single short marginal spines present slightly anterior to posterior margin.

Discussion.-P. communis is distinguishable from $P$. prolongus, the most similar species of Pseudagnostus presently recognized within the Dunderberg shale, by having all parts of the cephalon and pygidium better defined and by having marginal pygidial spines. The stratigraphic ranges of the two species are also different. $P$. communis is found in most collections from the lower half of the Dunderberg shale. P. prolongus is known only from collections in the upper part of the Dunderberg shale.

Occurrence: Abundant lower $130 \mathrm{ft}$ of Dunderberg shale; units A-C. USGS colln. 789-CO, 795-CO, 809-CO, 873-CO, 952-CO, 953-CO, 2294-CO, 2296-CO-2300-CO.

Figured specimens: Plesiotypes, cephalon and pygidium, USNM 136832a, b, USGS colln. 2299-CO.

\section{Pseudagnostus prolongus (Hall and Whitfield)}

Plate 4, figures 5, 6

Agnostus prolongus Hall and Whitfield, 1877, p. 230, pl. 1, figs. $30,31$.

Pseudagnostus prolongus (Hall and Whitfield). Palmer, 1955, p. 98 , pl. 19, figs. 17, 22 . (Fig. 18 belongs to an unnamed species, see below.)

Diagnosis.-Specimens of Pseudagnostus with distinct cephalic border but with glabella hardly defined on external surface. Pygidium with anterior part of axial lobe poorly defined by dorsal furrow. Pseudolobe not defined. Marginal spines lacking.

Discussion.-Collections from the Dunderberg shale made in 1957 have provided new information about this species. The type cephala of $P$. prolongus come from a block of limestone containing a pygidium of sigmocheilus serratus n. sp., a characteristic trilobite in the upper Dunderberg shale. Pygidia of a nearly smooth pseudagnostid, also from the upper D'mderberg shale, lack marginal spines and are associated with cephala indistinguishable from $P$. prolongus. The lower part of the overlying Windfall formation has a species of Pseudagnostus with a cephalon that is also nearly indistinguishable from $P$. prolongus but with a pygidium that has marginal spines. It now seems that this pygidium was mistakenly identified as P. prolongus (Palmer, 1955, pl. 19, fig. 18). Tre correct association of cephalon and pygidium is here figured.

Occurrence: Moderately common, 140-200 ft above base of Dunderberg shale; unit C. USGS colln. 864-CO, 2301-CO, 2302- $\mathrm{CO}$.

Figured specimens: Plesiotypes, cephalon and pygidium, USNM 136833a, b, USGS colln. 2301-CO. 


\section{Pseudagnostus? acutus (Kobayashi)}

Plate 4, figures 10-12

Homagnostus acutus Kobavashi, 1938, p. 172, pl. 16, figs. 18-22.

Diagnosis._Specimens of ?Pseudagnostus with posterior part of axial lobe distinctly inflated, well defined, slightly pointed posteriorly, reaching marginal furrow on axial line.

Cephalon without known distinctive characteristics.

Discussion.-Three pygidia from two different collections in the Dunderberg shale seem to be conspecific with $H$. acutus. The change in generic assignment is made for two reasons: first, the axial lobe of the pygidium reaches to the marginal furrow; and second, one specimen has muscle scars that are virtually like those of Pseudagnostus (Palmer, 1955, pl. 20, fig. 11 ). The convergent pairs of small scars on the posterior portion of the axial lobe have not been observed on any specimen of Homagnostus. In addition, the furrow between the first and second segments of the axial lobe does not curve inward and forward from the dorsal furrow as it does on most species of Homagnostus. The cephalon figured by Kobayashi, however, lacks a preglabellar median furrow; but there is no certainty in the small type collection that it is correctly assigned to the species. Until a cephalon can be certainly established for this species, its generic assignment must remain doubtful. If this species is properly placed in Pseudagnostus, it differs from all known species of Pseudagnostus by having the pseudolobe fully defined.

Occurrence: Rare, $40-60 \mathrm{ft}$ above base of Dunderberg shale : unit B. USGS colln. 2296-CO, 2297-CO.

Figured specimens: Plesiotypes, pygidia, USNM 136836a, b, USGS colln. 2297-CO.

\section{Subfamily GERAGNOSTINAE Howell}

\section{Genus homagnostus Howell}

Homagnostus Howell, 1935, p. 15; Kobayashi, 1939, p. 162; Whitehouse, 1939 , p. 261 ; Shimer and Shrock, 1944, p. 600 ; Lochman and Duncan, 1944, p. 139; Shaw, 1951, p. 110. oncagnostus Whitehouse, 1936, p. 84.

Geragnostus Palmer, 1954, p. $719 ; 1955$, p. 88 (G. tumidosus only).

Type species.-Agnostus pisiformis obesus Belt, 1867. p. 295, pl. 12, fig. 4.

Diagnosis.-Cephalon with well-defined bilobed glabella and distinct border. Preglabellar median furrow, if present, incomplete; generally deepest near glabella and fading out before reaching marginal furrow.

Pygidium with prominent well-defined axial lobe generally broader than pleural lobes. Posterior portion of axial lobe generally parallel sided or expanded slightly, well defined posteriorly, reaching nearly to marginal furrow.
Description.-Generally small agnostids (about 5 mm or less in length). Cephalon with well-defined border, narrowest at posterolateral corners; widest anterolaterally. Glabella well defined by dorsal furrows. Posterior lobe prominent, with poorly defined median node. Anterior lobe clearly separated from posterior lobe by transverse furrow, generally distinctly lower than posterior lobe. Basal lobes simple. Preglabellar median furrow, if present, deepest near glabella, generally disappears anteriorly before reaching marginal furrow.

Pygidium with prominent axial lobe that is generally wider than pleural lobes. A prominent median node located on axial lobe at jumction $b^{+}$ween second axial segment and posterior part of axial lobe. Furrows outlining first axial segment generally curved forward to cut anterior margin and divide first segment transversely into three parts. Posterior part of axial lobe parallel sided or, more commonly, slightly expanded posteriorly, well defined, reaching nearly to marginal furrow. Border well defined, gonerally with pair of short posterolateral marginal spines.

Surface smooth or coarsely pitted.

Discussion.-In two earlier papers (Palmer, 1954, 1955) H. tumidosus (Hall and Whitfield) has been placed in Geragnostus because it lacked a preglabellar median furrow and because of similarity in form of the axial lobe of the pygidium to that of some species of Geragnostus. The appearance of $H$. obesus (Belt) in the lower part of the Dunderberg shale emphasizes the close relationship between $H$. tumidosus and $H$. obesus, and new material shows that some cephala of H. tumidosus have a short remnant of a preglabellar median furrow just in front of the glabella. Furthermore, the group of agnostids typified by $H$. obesus, with the posterior part of the axial lobe on the pygidium slightly expanded, seems to be characteristic of older beds than those bearing typical forms of Geragnostus that have the posterior part of the axial lobe characteristically tapered posteriorly. There is now sufficient evidence both morphologically and stratigraphically for considering Homagnostus and Geragnostu. as distinct but related genera.

Westergard (1947) believed that Homagnostus should be no more than subgenerically se yarated from Agnostus because of observed overlap in form between species of the two taxa. Although a suite of $H$. obesus (Belt) from Scandinavia was not available for study, several specimens of coquina of Agnostus pisiformis (Linnaeus) from Ringsaker, Norway, and many specimens closely related to, if not conspecific with, H. obesus from Western United States were examined. The relatively slender, somewhat tapered, axial lobe of pygidia of 4 . pisiformis and the general presence of 
a well-defined complete preglabellar median furrow are characteristics that show a greater degree of difference from $H$. obesus than $H$. obesus does from $H$. tumidosus. Agnostids have so few characters for use in discrimination of taxa that apparent overlap of morphologic features as cited by Westergard is a constant problem. However, inclusion in one genus of populations as distinct as $A$. pisiformis and $H$. obesus may oversimplify an extremely complex situation. Agnostus, Homagnostus, and Geragnostus are here considered to be related taxa of comparable rank, worthy of designation as genera.

\section{Homagnostus tumidosus (Hall and Whitfield)}

Plate 4, figures 1, 2

Agnostus tumidosus Hall and Whitfield, 1877, p. 231, pl. 1, fig. 32.

Geragnostus cf. G. tumidosus (Hall and Whitfield). Palmer, 1954 , p. 719 , pl. 76 , figs. 4,6 .

Geragnostus tumidosus (Hall and Whitfield). Palmer, 1955, p. 89 , pl. 19 , figs. 3,4 ; pl. 20 , figs. $1-3,12,15$.

Diagnosis.-Specimens of Homagnostus with preglabellar furrow absent or represented only by short anteriorly directed notch in furrow in front of glabella. Pygidium with first segment of axial lobe generally not distinctly trilobate. Combined length of first two segments less than length of posterior portion of axial lobe.

Discussion.-This species has been discussed in considerable detail (Palmer, 1955). Additional observations have come from study of collections made in 1957. Some cephala have a short preglabellar median furrow that is barely more than an anteriorly directed notch in the dorsal furrow in front of the glabella. A few well-preserved molds of cephala are finely granular.

H. tumidosus is distinguishable from $H$. obesus (Belt) from slightly older beds in the Dunderberg shale principally by lacking a distinct development of the preglabellar median furrow.

Occurrence: Abundant, 50-220 ft or more above base of I underberg shale; units B, C. USGS colln. 86t-CO, 872-CO, S73-( $\mathrm{O}, 952-\mathrm{CO}-955-\mathrm{CO}, 2297-\mathrm{CO}-2302-\mathrm{CO}$.

Figured specimens: Plesiotypes, cephalon and pygidium, USNII 136831a, b, USGS colln. 2299-CO.

\section{Homagnostus obesus (Belt) \\ Plate 4 , figures $\boldsymbol{i}-9$}

Agnostus pisiformis obesus Belt, 1867, p. 295, pl. 12, fig. 4; Lake, 1906, p. 9, pl. 1, figs. 13, 14; Westergard, 1922, p. 116, 193 , pl. 1, fig. 4 .

Homagnostus obesus (Belt). Howell, 1935, p. 17, figs. 11, 12; Shimer and Shrock, 1944, pl. :251, figs. 9, 10: Wilson, 1954, pl. 25, fig. 19, pl. 26, figs. 23,27 .

Almostus (Homagnostus) obcsus (Belt). Westergard, 1947, p. 3, pl. 1, figs. 10, 11.
Diagnosis.--Specimens of Homagnostus with preglabellar median furrow generally apparent for about half distance from glabella to marginal furrow. Pygidium with first segment of axial lobe somewhat trilobate.

Discussion.-Specimens in two collections in the lower part of the Dunderberg shale are indistinguishable from the specimen figured by Westergard (1922, pl. 1, fig. 4) as Agnostus pisiformis obesus. They also apparently are conspecific with specimens figured as H. obesus, but not described, by Wilson (1954).

Certain identification of $H$. obesus is probably not possible on pygidia alone. Although the pygidium here figured has a distinctly trilobate division of the first segment of the axial lobe, some specimens of $H$. tumidosus approach this condition. The cephala are unlike any observed for $H$. tumidosus. Some specimens in USGS collection 2296 have a coarsely pitted surface. This feature seems to be variable within a population.

Occurrence: Rare, 10 (?)-40 ft above base of Dunderberg shale; units A, B. USGS colln. (?) 2294-CO-2296-CO.

Figured specimens: Plesiotypes cephalon and pygidium, USNM 136834a, b, USGS colln. 2296-CO. Cephalon, USNM 136835, USGS colln. 2295-CO.

\section{Subfamily PHALACROMINAE Corda}

\section{Genus PHALACROMA Corda}

Phalacroma Corda, 1847, p. 159; Kobayashi, 1939, p. 136 ; Westergard, 1946, p. 92.

Type species.-Battus bibullatus Barrande, 1816, p. 14.

Diagnosis.-Agnostidae with smooth cephalor, with or without border or median tubercule. Pygidium with axial lobe not defined; broad well-defined unspined border present.

\section{Phalacroma? sp.}

Plate 4, figure 13

A single cephalon of a Phalacroma-like agnostid is recorded here primarily to show the presence of agnostids of this type in the Dunderberg fauna. The cephalon is completely smooth, with no trace of a border. Only the posterior marginal furrow, the occipital ring, and the posteriormost parts of the basal lobes of the glabella are apparent. Although the specimen does not seem to differ significantly from specimens of $P$. glandiforme (Angelin) except in size, correct generic assignment cannot be made without knowledge of the associated pygidium.

orcurrence: Very rare, about $90 \mathrm{ft}$ above base of Dunderherg shale; unit B. USGS colln. 2300-CO.

Figured specimen: Cephalon, USNM 136837, USGS colln. 2300-CO. 


\section{Superfamily PTYCHOPARIOIDEA Richter} Family ELVINIIDAE Kobayashi

History.-Elviniidae was proposed by Kobayashi (1935) as a subfamily of the Ptychoparidae. It was raised to family status and enlarged in 1953 by both Lochman and Hupé, though the generic groupings of these authors include only one common genus besides Elvinia. Hupé (1955) presents the same information about the Elviniidae as in 1953 but adds diagnoses of the genera included in the family. Henningsmoen (1957) accepts the grouping of genera proposed by Lochman as representative of a subfamily contrasting with another subfamily grouping including Taenicephatus and related genera corresponding for the most part to the Parabolinoididae of Lochman (1956).

As conceived by Kobayashi, Hupé, and Henningsmoen, the Elviniidae seems to be an artificial grouping of genera in which the probability of close genetic relationship for most of the genera is slight. For example, Taenicephatus is included in the Elviniidae by all three authors, and Conaspis was included by Kobayashi and Hupé. Lochman (1956) has shown, based on the work of Bell, Feniak, and Kurtz (1952) and Berg (1953), that Taenicephalus and Conaspis belong to separate families having little, if anything, in common with Elvinia.

Lochman (1953) includes E7vinia, Maladioides, Drumaspis, and Chariocephalus in the Elviniidae and discusses their relationships in considerable detail.

Maladioides is a genus known only from Manchuria and Korea whereas the other genera occur only in North America. Plaster casts of the types of $M a l a-$ dioides asiaticus Kobayashi, the type species of Maladioides, show that the trilobite had a pygidium with a border, axial lobe, and overall shape unlike any of the trilobites included here in the Elviniidae. The cranidium is not well-enough preserved for adequate comparison. If Maladioides has any real relationships to American Upper Cambrian trilobites, they apparently are more with the Housiidae, as here used, than with the Elviniidae.

Drumaspis and Chariocephalus may be related Elriniu. However, they are found in beds separated from those bearing Elvinia by a significant sequence of fossiliferous Upper Cambrian beds lacking intermediate forms. Furthermore, one of the major UTpper Cambrian faunal breaks occurs between the faunas bearing Elvinia and those bearing Drumaspis and Chariocephalus. Although Drumaspis and Chariocephalus pygidia have characteristics typical of the Elviniidae, the character of the anterior branches of the facial suture is unknown. Until more is known of these trilobites, their assignment to the Elviniidae should be considered only tentative.
Definitive features.--The five genera included here in the Elviniidae (Elvinia, Elviniella, Elburgia, Dunderbergia, and Irvingella) share, in addition to stratigraphic continuity, the following morphologic features: Glabella prominent, generally well-defined at sides by deep dorsal furrow; border and doublure on cranidium and free cheek narrow, of nearly constant width, subcircular in cross section; rostrum present; facial suture submarginal, along at least middle-third of anterior margin of cranidium (fig. $8 \mathrm{C}$ ) ; border and

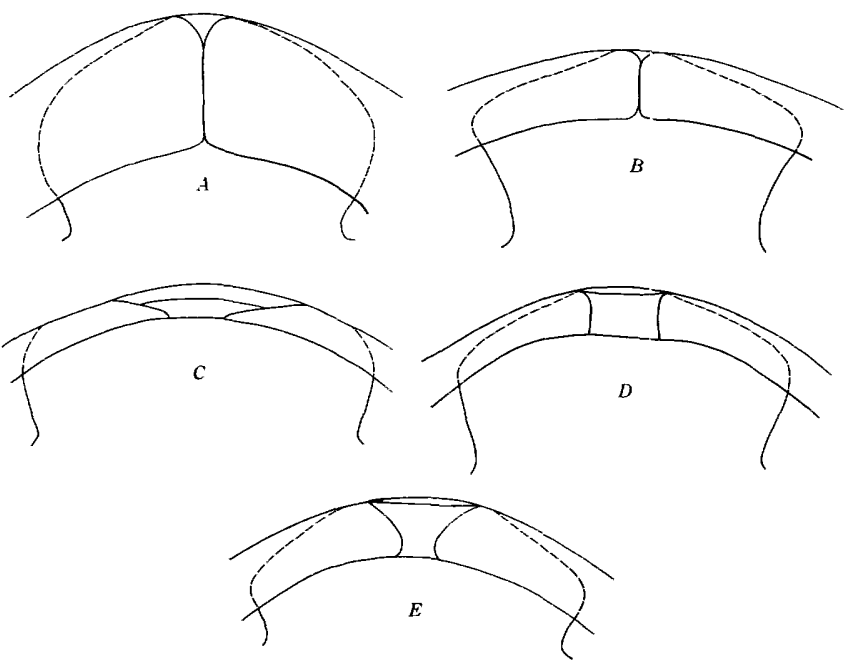

Figure 8.-Comparison of the ventral courses of the cephalic sutures in some Late Cambrian trilobites. A, Pterocephalia; B, Housia; C, Dunderbergia; D, Prehousia; E, Aphelaspis.

donblure of pygidium narrow, of nearly constant width; axial lobe of pygidium prominent, generally reaching nearly to border, connected to it by poorly defined postaxial ridge.

Discussion.-Of the features listed abcve, the character of the border and doublure on the cephalon and pygidium and the course of the cephalic sutures seem to be most critical family features.

The possible interrelationships of the genera of the Elviniidae in the Dunderberg shale leave the problem of subfamily groupings unresolved. Unf crtunately for the present study, species of genera other than Dunderbergia are not common. Using only cranidia, several potential lineages are apparent (cf., pl. 5, 6). Elviniella $\rightarrow$ Irvingella $($ Parairvingella $) \rightarrow$ Irvingella (Irvingella) might be included in one lineage by assumming reduction in the length of the frontal area and gradual decrease in the taper of the glabella for these three taxa with long arcuate palpebral lobes. This lineage could be contrasted with one from Dunderbergaa $\rightarrow$ Elburgia $\rightarrow$ Elvinia in which the posterior glabellar furrows are first deepened, and then connected across the top of the glabella. These three genera have similar pygidia. In addition, Dunderbergia and Elburgia share a bluntly pointed anterior 
margin and marginal furrow; and, Elburgia, on the basis of observation of specimens from California, has free cheeks indistinguishable from those of Elvinia.

Alternative possibilities might be to derive Elvinia from Elviniella by gradual reduction in length of the palpebral lobe or to group the genera with noticeably arcuate palpebral lobes and transglabellar posterior furrows together in one subfamily (that is, Elviniella, E7vinia, Irvingella.) and leave the genera with simple palpebral lobes (Dunderbergia. Elburgia) in a second subfamily.

Obviously, more information about the genera of the Elviniidae is needed before an acceptable subfamily classification can be prepared. Perhaps studies of the faunas of the Dunderberg shale elsewhere in the Great Basin will provide this information.

\section{Genus DUNDERBERGIA Walcott, 1924}

Text figure 9

Dunderbergia Walcott, 1924 , p. $56 ; 1925$, p. 84 ; Resser, 1935 , p. 23; Raymond, 1937, p. 1112; Kobayashi, 1938, p. 181; Shimer and Shrock, 1944, p. 625; Palmer, 1954, p. 760.

Type species.-Crepicephalus (Loganellus) nitidus Hall and Whitfield, 1877, p. 212, pl. 2, fig. 8.

Diagnosis.-Elviniidae with prominent subquadrate glabella; glabellar furrows hardly visible. Length of palpebral lobe about $1 / 3$ to $1 / 4$ length of glabella including occipital ring. Line comnecting midlengths of palpebral lobes crosses glabella just posterior to junction of second glabellar furrows with dorsal furrow. Anterior margin and marginal furrow commonly come to a blunt point on axial line instead of forming an even curve. Thorax includes either (or both) segments with pleural spines short, laterally directed, or long, backwardly directed. Pygidium subsemicircular in outline, widest at anterolateral corners. Border narrow, of nearly constant width. Axial lobe prominent, subparallel sided, bluntly rounded posteriorly. Pleural lobes nearly flat.

Modification of this diagnosis from that given earlier (Palmer, 1954) results from a consideration of the characters of the genera assigned to the Elviniidae.

Description.-Medium-sized trilobites, probably few longer than $40 \mathrm{~mm}$. Form of entire exoskeleton unknown. Cephalon subsemicircular in outline, moderately to strongly arched transversely and longitudinally. Cranidium exclusive of posterior limbs subquadrate in outline, anterior margin commonly bluntly pointed. Glabella prominent, elevated above brinr and cheeks, tapered slightly forward, bluntly rounded or truncate anteriorly. Width just anterior to occipital furrow nearly equal to length exclusive of occipital ring. Three pairs of shallow glabellar furrows may be present. Posterior pair generally with bigenicu-

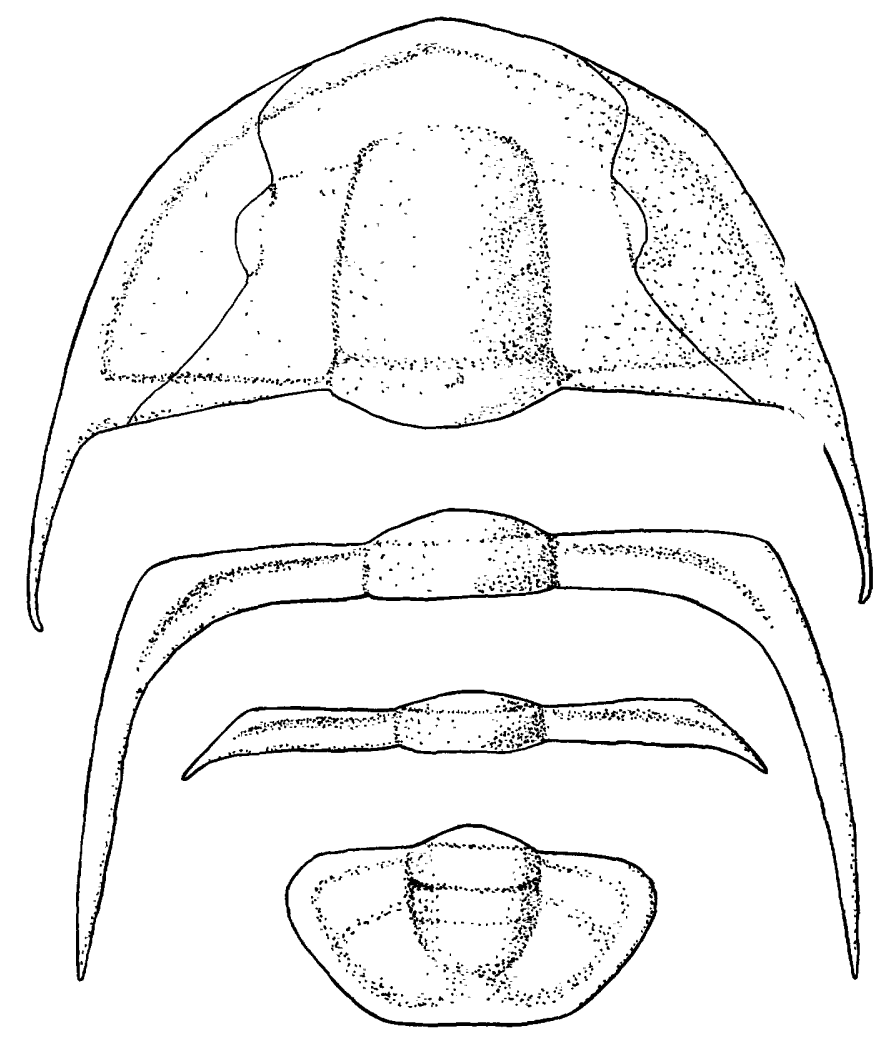

Figure 9.- Partial reconstruction of Dunderbergia polybothra n. sp., about $\times 8$.

late form. Occipital furrow always moderately deep, particularly at distal ends. Occipital ring with low median node adjacent to occipital furrow. Dorsal furrow deep at sides of glabella; shallow across front. Border distinct, moderately to strongly convex; length one-half or slightly less than that of brim. Marginal furrow deep, generally comes to blunt point or axial line. Brim gently to moderately convex. Fixed cheeks gently to moderately convex, horizontal or slightly upsloping; width about one-third basal glabellar width. Palpebral lobes semicircular in outline moderately well defined by shallow palpebral furrow; width one-third or slightly more that of cheek; length about $1 / 3$ to $1 / 4$ length of glabella including ocnipital ring. Ocular ridges generally visible, anterior margin best defined. Posterior limbs sharply pointed, length (transverse) generally slightly greater than basal glabellar width. Marginal furrow on posterior limb broad, deep; broadens laterally. Anterior course of facial suture slightly divergent from palpebral lobe to marginal furrow; turns inward across border, cuts anterior margin at point slightly less than or o-half distance from anterolateral corners of cranidium to axial line. Connective sutures convergent posteriorly, not meeting on axial line. Rostral suture b?neath midlength (sagittal and exsagittal) of border (fig. 8C). Posterior course of facial suture divergent-sinuous. 
Free cheek with well-defined continuous lateral and posterior marginal furrows; posterior marginal furrow generally deepest. Border narrow. Ocular platform gently convex, twice or more width of border. Genal spine short, sharply pointed, tip on some species curved slightly inward; length generally less than axial length of glabella on associated cranidium.

Hypostome and rostrum not known.

Form of thorax unknown. Thoracic segments of the same species with pleural spines either short, sharp, and directed laterally; or long, slender, and directed posteriorly. Width (transverse) of pleurae, from dorsal furrow to geniculation, between 1 and 2 times width of axial ring.

Pygidium short and wide, nearly flat except for prominent axial lobe. Axial lobe with 1 or 2 prominent ring furrows and with blunt indistinct posterior termination near inner margin of border. A low poorly defined median ridge connects axial lobe with border. Border well defined along all of margin except directly on axial line; width about half greatest width of pleural platform. A slight median indentation of margin may be present.

Surface of exoskeleton variously ornamented. External surface of cranidium and cheeks entirely smooth, partly or wholly granular, or coarsely pitted. Surface of mold of cranidium and cheeks ornamented with either pits or fine pits interspersed with coarse granules. Fine-granular and coarse-pitted ornament not apparent on surface of mold.

Ornamentation of surface of thoracic segments comparable to that of cheeks and cranidium.

Pygidium with top surface of axial lobe and border always bearing granules. Border generally also with prominent terrace lines. Pleurae either smooth, coarsely (but weakly) pitted, or granular. Surface of mold generally finely pitted.

Discussion.-Walcott (1924, p. 56) proposed Dunderbergia to include Crepicephalus (Loganellus) nitidus Hall and Whitfield and gave a brief diagnosis of the genus. Other brief mentions of some of the characteristics of Dunderbergia were given by Walcott (1925, p. 83), Raymond (1937, p. 1112) and Kobayashi (1938, p. 181). A more detailed description of the genus was given by Palmer (1954, p. 760) and is repeated with only slight modification here.

Thirteen species, besides the type species, have been assigned to Dunderbergia. These were Crepicephalus (Loganellus) maculosus Hall and Whitfield, Crepicephalus (Loganellus) simulator Hall and Whitfield, Crepicephalus (Loganellus) granulosus Hall and Whitfield, Ptychaspis pustulosa Hall and Whitfield, Ptychoparia suada Walcott, and Dunderbergia halli Resser assigned by Resser (1935, p. 23, 24); Dunderbergia? declivita (Miller, 1936, p. 30$)$; Crepicephalus (Loganellus) anytus Hall and
Whitfield (Resser, 1937, p. 9); Dunderbergia vermontensis (Raymond, 1937, p. 1120); Dunderbergia canadensis, $D$. convexa, and $D$. quadrata assigned by Kobayashi (1938, p. 181, 182) who included the latter two species along with $D$. pustulosa Hall and Whitfielc', D. maculosa (Hall and Whitfield), and D. granulosa (Hall and Whitfield) in a new subgenus, Megadunderbergia; and Dunderbergia variagranula (Palmer, 1954, p. 761).

Wilson (1948, p. 33) considered Dunderbergia? declivita Miller a synonym of Deadwoodia duris (Walcott). Wilson, (1951, p. 636) also removed Dunderbergia suada (Walcott) from the genus and considered it a senior synonym of Dellea wilbernsensis Wilson (1949, p. 35). Shaw (1952, p. 475) pointed out that Dunderbergia vermontensis Raymond is a young individual of Meteoraspis? minuta (Raymond). A review of the 11 other species during this study shows that only $D$. nitida (Hall and Whitfield), D. anyta (Hall and Whitfield), $D$. quadrata Kobayashi, and $D$. variagranula Palmer are recognizable species remaining in Dunderbergia. Of the seven other species, $D$. simulator (Hall and Whitfield) was considered a synonym of $D$. nitida (Hall and Whitfield) by Walcott (1884, p. 57), was later resurrected by Resser (1935, p. 24), and is here, again, considered a synonym of $D$. nitida. D. granulosa (Hall and Whitfield) is removed from Dunderbergia and assigned to the new genus Elburgia. $D$. halli Ress?r is based on a pygidium correctly assignable to Housia (p. 75); and $D$. maculosa (Hall and Whitfield) (pl. 5, fig. 5), $D$. pustulosa (Hall and Whitfield) (pl. 5, fig. 8), D. canadensis Kobayashi and $D$. convexa Kobayashi are based on such poor material that the specimens, though probably belonging to Dunderbergia, cannot be assigned with confidence to any of the species of the genus here recognized and are considered indeterminate. The names should be restricted to the type specimens.

Because D. maculosa (Hall and Whitfield), the type species of Megadunderbergia Kobayashi, is considered an indeterminate species, the subgenus also must be considered indeterminate. No subgeners of Dunderbergia are recognized in this paper.

Species presently assigned to Dunderbergia:

Dundbergeria anyta (Hall and Whitfield)

bigranulosa $\mathrm{n}$. sp.

nitida (Hall and Whitfield)

polybothra n. sp.

quadrata Kobayashi

variagranula Palmer

maculosa (Hall and Whitfield)

$\left.\begin{array}{l}\begin{array}{l}\text { pustulosa (Hall and Whitfield) } \\ \text { canadensis Kobayashi } \\ \text { convexa Kobayashi }\end{array}\end{array}\right\}$ Restric'ed to holotype

Dunderbergia bigranulosa n. sp.

Plate 5, figures $10-13,15-23$

Diagnosis.-Members of Dunderbergia with external surface of cephalon bearing low scrttered coarse 
granules on brim, fixed cheeks, posterior limbs, and ocular platforms; fine close-spaced granules on border, top of glabella, and outer margins of palpebral lobes. Surface of mold shows position of coarse granules; surface beneath fine-granular areas is finely pitted. Pygidium with fine granules on border and top of axial lobe; scattered low coarse granules on pleural platforms.

Discussion.-Some variation in degree of expression and detailed distribution of the coarse granules was observed within collections of $D$. bigranulosa. On some specimens the coarse granules are only apparent after the specimen has been lightly whitened and observed with low oblique lighting (pl. 5, fig. 13). On specimens from USGS collection 795, associated with $D$. nitida (Hall and Whitfield), the coarse granules are exceptionally prominent (pl. 5, figs. 10, 11), and in this way resemble the coarse granules of $D$. variagranula Palmer; however, the border and glabella have the fine granules characteristic of $D$. bigranulosa.

Two types of free cheeks, perhaps indicating dimorphism within the species, have been found in collections of $D$. bigranulosa and $D$. variagranula. On one type, the border broadens slightly anterior to the base of the genal spine and it is distinctly flattened. On the other type, the border maintains an even width and it is gently convex (cf. pl. 5, figs. 16, 17).

An unusual, apparently pathologic, pygidium is present in USGS collection 2295-CO (pl. 5, fig. 23). This specimen includes two distorted thoracic segments that have their right pleurae free and their left pleurae fused with each other and the remainder of the pygidium.

Occurrence: Abundant, lower $40 \mathrm{ft}$ of Dunderberg shale; unit A. USGS colln. 795-CO, 2294-CO, 2295-CO.

Figured specimens: Holotype cranidium, USNM 136847, USGS colln. 2295. Paratypes: Cranidium, USNM 136848a, USGS colln. 2295-CO ; cranidia, USNM 136846a, b, USGS colln. 795-CO ; cranidium, USNM 136849b, USGS colln. 2294-CO; free cheeks, USNM $136848 \mathrm{~b}$, c. USGS colln. 2295-CO; free cheek, USNM 136849a, USGS colln. 2294-CO; pygidia, USNM 136848d-f, USGS colln. 2295-CO; pygidium, USNM 136849c, USGS colln. 2294-CO.

\section{Dunderbergia nitida (Hall and Whitfield)}

Plate 4, figures 14-21, 23, 24

Crepicephalus (Loganellus) nitidus Hall and Whitfield, 1877, p. 212, pl. 2, fig. 8 .

Crepicephalus (Loganellus) simulator Hall and Whitfield, 1877, p. 218 , pl. 2 , figs. $16-18$.

Ptychoparia nitidus (Hall and Whitfield). Walcott, 1884, p. 57.

Dunderbergia nitida (Hall and Whitfield). Walcott, 1924, p. 56 , pl. 11 , fig. 2 ; 1925 , p. 84 , pl. 16 , fig. 4 ; Shimer and Shrock, 1944, pl. 264, fig. 29.

Dunderbergia simulator (Hall and Whitfield). Resser, 1935, p. 24.
Diagnosis.-Members of Dunderbergia with external surface of exoskeleton smooth except for top of axial lobe and border of pygidium which bear fine close-spaced granules and border of free cheek which has terrace lines. Surfaces of molds of all parts of exoskeleton are finely pitted.

Discussion.-This species is the most commor species of Dunderbergia in the collections studied. Some cranidia from USGS collection 2300-CO have rare low barely discernible coarse granules on the brim, suggesting that $D$. nitida may have been derived from a form like $D$. bigranulosa through the loss of the fine granules on the border and glabella.

The holotype of this species was not designated by Hall and Whitfield. Two specimens in the typ? collection have handwritten labels bearing the or: ginal name pasted on the rock. One, USNM $24572 \mathrm{~b}$, a mold, (pl. 4, fig. 16) is the specimen cited by Walcott (1925, p. 132, fig. 5) as an "original type specimen." The illustration given by Walcott is not of this specimen, nor is it of the other with the handwritten label. The second specimen, USNM 24572, preserves enough of the external surface (pl. 4, fig. 15) to show that it was for the most part smooth. Inasmuch as Walcott did not designate holotypes of the other species in his 1925 paper, Walcott's cited comment is interpreted here to mean only that he was illustrating one of the original types. Because the illustration does not conform to either of the labeled specimens, Walcott's comment is not considered a valid citation of a lectotype for $D$. nitida, and the specimen bearing USNM 24572 and the handwritten label " $C$. $(L$. $)$ nitidus" is here designated as lectotype of the species.

The pygidium illustrated for $D$. nitida by Walcott (1925, pl. 16, figs. 6, 7) and Shimer and Shrock (1944, pl. 264, fig. 30) is a Housia pygidium (p. 75; pl. 7, fig. 8).

Occurrence: Common, from 50-200 ft above the bise of the Dunderberg shale; units B, C. USGS colln. 789-CO, 795$\mathrm{CO}, 864-\mathrm{CO}, 872-\mathrm{CO}, 873-\mathrm{CO}, \quad 953-\mathrm{CO}-955-\mathrm{CO}$, 2295-CO2302-CO.

Figured specimens: Lectotype cranidium, USNM 24572. Paratype cranidium, USNM 24572b. Plesiotypes: Cranidium, holotype of $D$. simulator (Hall and Whitfield), USNM 24575; cranidia, USNM 136838b, c, USGS colln. 2300-CO; free cheeks, USNM 136838d, f, USGS colln. 2300-CO; free cheek, USNM 136839. USGS colln. 873-CO; pygidia, USNM 136838a, e, USGS colln. 2300-CO.

\section{Dunderbergia polybothra n. sp.}

Plate 5, figures 1-4, 6, 7, 9, 14

Dingnosis.-Members of Dunderbergia with surfaces of all parts of exoskeleton except top of axial lob? and border of pygidium bearing coarse pits. Pits most apparent on border of cephalon, top of glabella, and axial parts of thoracic segments; visible on other parts 
of exoskeleton only on exceptionally well-preserved specimens. Top of axial lobe and border of pygidium bear close-spaced granules. Surfaces of molds of all parts of exoskeleton are finely pitted.

Discussion.-This distinctive species is known from only two collections, where it is the only species of Dunderbergia present. It differs from all other species in the genus by having a pitted surface.

Occurrence: Moderately common, about $40 \mathrm{ft}$ above base of Dunderberg shale, unit B. USGS colln. 1297-CO, 2296-CO.

Figured specimens: Holotype cranidium, USNM 136845, USGS colln. 2296-CO. Paratypes, cranidium, free cheeks, thoracic segments, and pygidium, USNM 136844a-f, USGS colln. 2296-CO.

\section{Dunderbergia variagranula Palmer}

Plate 4, figures 22, 25, 26, 28, 29

Dunderbergia variagrenula Palmer, 1954, p. 761, pl. 88, fig. 7 .

Diagnosis.-Members of Dunderbergia with external surfaces of all parts of exoskeleton bearing scattered coarse granules. Surfaces of molds of all parts of exoskeleton also bearing scattered coarse granules.

Discussion.-In view of observations made on reasonably abundant material of this species in the Eureka district, the only illustrated specimen from Texas now retained in this species is the holotype (Palmer, 1954 , pl. 88, fig. 7). The other three illustrated specimens may represent a species not known in the Eureka district.

One difference was noted between the holotype and the Nevada specimens. Coarse granules are rare on the posterior limbs of the few specimens of $D$. variagranula from Nevada that have the limbs preserved. The posterior limbs of the holotype bear abundant coarse granules. Unfortunately, not enough specimens are known from either area to determine if this is a consistent difference. Because the distribution of coarse granules on other parts of the cranidium is somewhat variable among cranidia in a single collection, the Texas and Nevada specimens are here considered to be most likely conspecific.

D. quadrata Kobayashi (pl. 4, fig. 27) is represented by a single cranidium that has coarse granular ornament on both the external surface and the surface of the mold. Fine granules are also present on the border. These are characteristic features of $D$. variagranula. However, the cranidium of $D$. quadrata is three times larger than any cranidia of $D$. variagranula known, has a much more prominent glabella, and appears to have a relatively shorter frontal area and broader border. Although $D$. cariagranula may be a synonym of $D$. quadrata, more knowledge of $D$. quadrata is desirable before suppressing $D$. variagrunula.

A single small cranidium from USGS collection 2302 (pl. 4 , fig. 26 ) is tentatively referred to $D$. variagranula. It conforms to the species in all respects except that the border bears only close-spaced fine granules. Also, it occurs with $D$. nitida, about 120 feet higher than any collection in which granular species of Dunderbergia are common. This certainly indicates that the granular and smooth forms of Dunderbergia have a nearly common range in time. However, the abundance of granular species in the relatively common limestones of the lower Dunderberg, where smooth forms of Dunderbergia gre rare, and the reverse situation in the relatively rare limestones of the middle shaly part of the Dunderherg may indicate that the granular and smooth forms have different facies preferences.

Occurrence: Moderately common, 50-75 $\mathrm{ft}$ above the base of the Dunderberg shale; units B, C. USGS colln. 809-CO, 873-CO, 952-CO, 2297-CO, 2298-CO.

Figured specimens: Plesiotypes-cranidium $\varepsilon$ nd free cheek, USNM 136840a, b, USGS colln. 2297-CO; cranidium, USNM 136841, USGS colln. 2298-CO ; crandium, USNM 136842, USGS colln. 2302-CO ; pygidium, USNM 136843, USGs colln. 809-CO.

\section{Genus ELBURGIA n. gen.}

Text figure 10

Type species.-Crepicephalus (Loganellus) granulosus Hall and Whitfield, 1877, p. 214, pl. 2, figs. 2, 3.

Diagnosis.-Elviniidae with cranidium having palpebral lobes about one-third length of glabella including occipital ring, and with posterior pair of glabellar furrows deep, bigeniculate, connec ${ }^{+}$ed by a shallow furrow across top of glabella. Second glabellar furrows also conspicuous, only slightly cirved. Anterior glabeller furrows only conspicuous on mold. Pygidium and free cheeks not distinguishable from E7vinia.

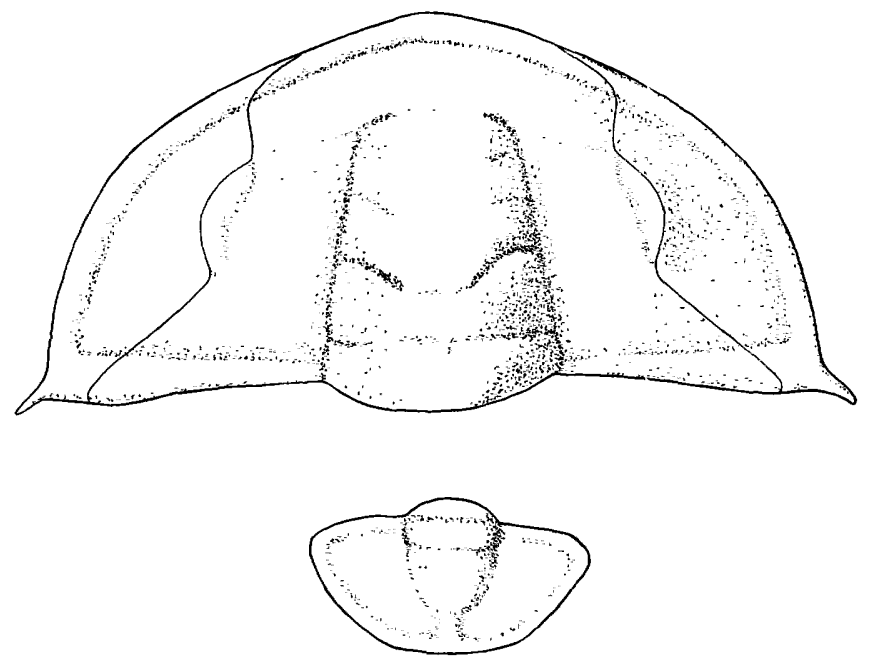

FiguRE 10.-Partial reconstruction of Elburgia quinnensis Resser, about $\times 6$.

Description.-Medium to large trilobites (as much as $90 \mathrm{~mm}$ in total length). Outline of cranidium, exclusive of posterior limbs, subquadrate; anterior mar- 
gin evenly rounded or bluntly pointed. Glabella prominent, elevated above cheeks, tapered forward, bluntly rounded or truncate anteriorly; with just anterior to occipital furrow about equal to length exclusive of occipital ring. Three pairs of glabellar furrows present. Anterior pair shallowest, short; middle pair moderately deep, reach about three-fourths distance to axial line; posterior pair deep, bigeniculate, connected across top of glabella by shallow furrow. All furrows more conspicuous on mold. Occipital furrow broad, deep. Occipital ring with low median node adjacent to occipital furrow. Dorsal furrow deep at sides and anterolateral corners of glabella, shallow across axial line. Border distinct, moderately to strongly convex, length one-half or slightly less that of brim. Marginal furrow broad, deep, with slight tendency to come to a blunt point on axial line. Brim gently to moderately convex. Fixed cheeks gently to moderately convex, nearly horizontal. Width slightly less than one-half basal glabellar width. Palpebral lobes moderately arcuate in outline; width about one-third width of cheek; length about one-third length of glabella including occipital ring. Palpebral furrow broad, well defined. Ocular ridges visible but not prominent; anterior margin best defined. Posterior limbs sharply pointed, length (transverse) equal to or slightly greater than basal glabellar width. Marginal furrow on posterior limb broad, deep, broadens laterally. Anterior course of facial suture only slightly divergent from palpebral lobes to marginal furrow; turns inward across border; cuts anterior margin and becomes submarginal at point slightly less than one-half distance from anterolateral corner of cranidium to axial line. Posterior course of facial suture divergent sinuous.

Hypostome rostrum and thoracic segments not known.

Free cheek and pygidium same as Elvinia (cf. figs. 10. 11).

Discussion.-This genus includes, at present, two species whose cranidial shape and stratigraphic ranges are intermediate between those of Dunderbergia and Elvinia. The form of the preglabellar area is characteristic of Dunderbergia, and the posterior glabellar furrows connected across the glabella are characteristic of Elvinia. These characters combined, plus the general prominence of all glabellar furrows, are the distinguishing characteristics of the species of Elburgia.

Species differentiation in Elburgia, as in Dunderbergia, is primarily based on the nature of the external surface and the surface of the mold of the cranidium.

Two cranidia representing this genus, but identified as Elivinia sp., were figured by Palmer and Hazzard
(1956, pl. 1, figs. 1, 2) from the Cornfield Springs and Nopah formations in California.

Elburgia granulosa (Hall and Whitfield)

Plate 6, figures 16, 17, 19

Crepicephalus (Loganellus) granulosus Hall and Whitfield. 1877, p. 214, pl. 2, figs. $2,3$.

Ptychoparia granulosus (Hall and Whitfield). Walcott, 1884, p. 57.

Dunderbergia granulosa (Hall and Whitfield). Resser, 1935, p. 24.

Dunderbergia (Megadunderbergia) granulosa (Hall and Whitfield). Kobayashi, 1938, p. 181.

Diagnosis.-Members of Elburgia with cranidium having external surface and surface of mold, exclusive of furrows and palpebral lobes, thickly covered with coarse granules.

Discussion.-No further comments on the character of this species have been published since the original description by Hall and Whitfield, though Walcott, Resser, and Kobayashi successively transferred it to three different genera or subgenera. Kobayashi (1938) included granulosa with Dunderbergia pustulosa (Hall and Whitfield) in a new subgenus, Megadundert srgia. The holotype of the type species of Megadunderhergia (D. pustulosa) is here considered (p. 66) an indeterminate specimen of Dunderbergia. Thus, Megadunderbergia is also indeterminate, and the identifiable species assigned to it require reassignment. $E$. granulosa, with its conspicuous E7vina-like glabellar furrows, does not fit the present concept of Dunderbergia and is here designated as the type species of E7burgia (see generic discussion). It is easil" distinguished from the only other species presently assigned to the genus $E$. quinnensis (Resser) ky the coarse granular nature of the external surface and the surface of the mold of the cranidium.

Occurrence: Rare, $45-70 \mathrm{ft}$ above base of Dunderberg shale: unit B. USGS colln. 795-CO; 2297-CO.

Figured specimens: Holotype cranidium, USNM 24573. Plesiotypes: Cranidium, USNM 136857, USGS colln. 2237-CO ; cranidium, USNM 136856, USGS colln. 795-CO.

\section{Elburgia quinnensis (Resser)}

Plate 6, figures 11-13, 15

Taenicephalus quinnensis Resser, 1942b, p. 105, pl. 21, figs. 18, 23.

Diagnosis.-Members of E7burgia with external surface of cranidium nearly smooth. Lateral parts of brim and of posterior limbs with numerous closespaced low granules visible only when specinen is whitened and viewed in extreme oblique lighting. Brim also bears scattered low coarse granules, also barely visible. Surface of mold with numerous fine pits most noticeable on brim and cheeks. Positions of coarse granules may be indicated by low elevations 
with terminal pits slightly larger than those on other parts of cranidium.

Discussion.-This species was described by Resser (1942, p. 105) as Taenicephalus quinnensis from a small collection of unknown stratigraphic position collected by J. E. Spurr while on reconnaisance in Nevada in 1899. Although the prominent glabellar furrows are reminiscent of Taenicephalus, the facial sutures do not cut the margin near the axial line as they seem to do in that genus, and no true species of Taenicephalus have the posterior pair of glabellar furrows connected across the glabella. Furthermore, this species is associated with a species of Sigmocheilus n. gen., a genus characteristically found in beds older than those bearing Elvinia. Taenicephalus is known only from beds younger than those bearing Elvinia.

Free cheeks and pygidia associated with cranidia of this species in the lower part of the Nopah formation, California, are virtually indistinguishable from those of Elvinia. A pygidium and free cheek, probably of Elburgia quinnensix, were figured by Resser from the small type collection from the Quinn Canyon Range, Nev.

Occurrence: Moderately rare, 70-100 ft above base of Dunderberg shale; unit B. USGS colln. 2298-CO, 2299-CO, 2300CO. Outside the Eureka district, this species has been recognized in collections from the Nopah formation in California and in Dunderberg equivalents in the Las Vegas quadrangle, Nevada.

Figured specimens: Holotype exfoliated cranidium, USNM 108838a, USNM loc 7j; Dunderberg(?) shale, Quinn Canyon Range, Nev. Paratype, cranidium, on same block as holotype, with external surface preserved. Plesiotypes: Cranidium, USNM 136855, USGS colln. 2298-CO ; cranidium, USNM 136438, USGS colln. 2299-CO.

\section{Genus EIVINIA Walcott, 1924}

Text figure 11

Elvinia Walcott, 1924, p. 56; 1925, p. 88; Bridge and Girty, 1937, p. 252; Kobayashi, 1938, p. 179; Shimer and Shrock, 1944 , p. 625 .

Moosia Walcott, 1924, p. 59 ; 1925, p. 106 .

Diagnosis.-Elviniidae with posterior glabellar furrows connected across glabella forming single arcuate furrow of nearly even depth. Other glabellar furrows rarely apparent. Palpebral lobes arcuate, length about one-third that of glabella including occipital ring. Width of fixed cheeks between $2 / 5$ and $1 / 2$ basal glabellar width. Anterior margin of cranidium evenly curved. Marginal furrow appears nearly straight in dorsal view. Anterior course of facial sutures nearly straight forward from palpebral lobes.

Free cheek with short sharp genal spine diverging from general curvature of cheek margin. Ocular platform broad, separated from moderately to strongly convex border by broad deep marginal furrow, connection between lateral and posterior marginal furrows shallow.
Pygidium subsemicircular in outline, wi dest at anterior margin. Border narrow, of nearly constant width. Axial lobe prominent, subparallel sided, bluntly rounded posteriorly. Pleural lobes nearly flat.

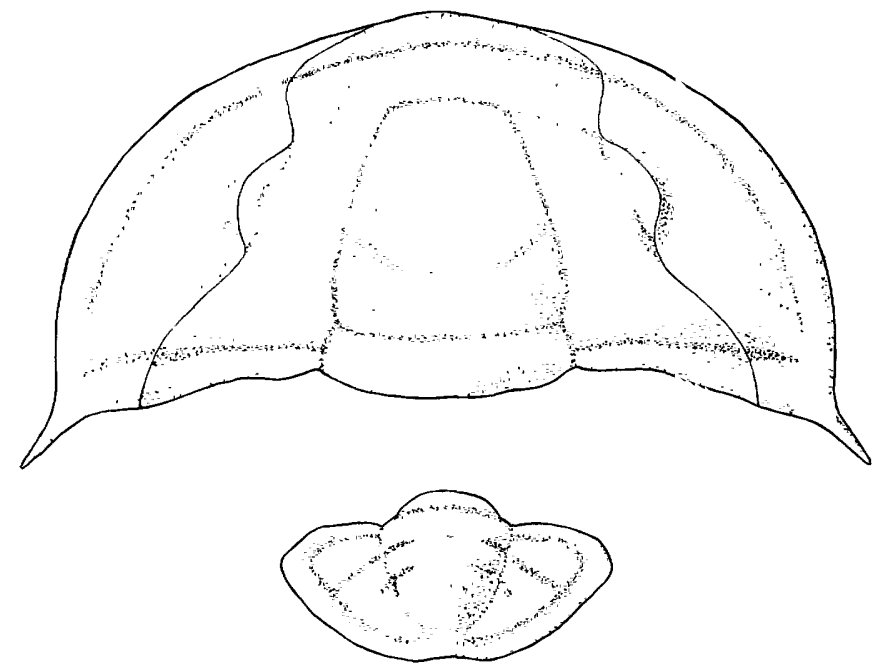

Figure 11.--Partial reconstruction of Elvinia roemeri (Shumard, about $\times 3$.

Discussion.-Bridge and Girty (1937, p. 252; pl. 69, figs. 1-21) described the genus in detail and illustrated specimens from many parts of the United States. The inclusion of $E$. granulata (Resser) in the genus requires the following slight modification in the otherwise excellent characterization given by Bridge and Girty: Frontal area with length (sagittal) of border equal to or less than length (sagittal) of brim. External surface smooth or granular.

Species differentiation in Elvinia is here based primarily on the nature of the surface of the cranidium and secondarily on the character of the frontal area. The inadequacy of minor variations of cranidial proportion for species differentiation withir Elvinia has already been treated by Bridge and Girty (1937) and Frederickson (1949).

\section{Elvinia roemeri (Shumard)}

\section{Plate 6, figure 7}

Dikelocephalus roemeri Shumard, 1861, p. 220, 221.

Crepicephalus (Loganellus) unisulcatus Hall and Whitfield, 1877, p. 216, pl. 2, fig. 22.

Ptychoparia matheri Walcott, 1912, p. 268, pl. 44, figs. 15-17.

Elvinia roemeri (Shumard). Walcott, 1924, p. 56, pl. 11, fig. 3 ; 1925 , p. 88 , pl. 17, figs. 9-13; Bridge, 1933, p. 232, pl. 2, figs. 17-19; Miller, 1936, p. 30, pl. 8, fig. 36; Bridge and Girty, 1937, p. 251, pl. 69, figs. 1-22; Shimer and Shrock, 1944, pl. 264, figs. 34-37; Wilson, 1949, p. 38, pl. 10, figs. $5,9,10,12,13$; Frederickson, 1949, p. 352, pl. 69, figs. 19 21; Lochman, 1950, pl. 47, figs. 21-23; Wilson, 1951, p. 642, pl. 92, figs. 18-22; Nelson, 1951, p. 775, pl. 107, fig. 8; Bell, and others, 1952 , p. 183 , pl. 30, figs. 1a-d.

Moosia grandis Walcott, 1924, p. 59, pl. 14, fig. 9; 1925, p. 107, pl. 23, figs. 20, 21. 
Elvinia tetonensis Resser, 1937, p. 12.

Elvinia texana Resser, 1938, p. 30.

Elvinia shumardi Resser, 1938, p. 30; Shimer and Shrock, 1944, pl. 264, figs. 41,42 .

Elvinia bridgei Resser, 1938, p. 31; 1942b, p. 97, pl. 18, figs. 28-31; pl. 19, figs. 1-5.

Elvinia missouriensis Resser, 1938, p. $31 ; 1942$ b, p. 96 , pl. 18, figs. 13-17.

Elvinia dakotensis Resser, 1938, p. 32.

Elvinia utahensis Resser, 1938, p. 32; 1942b, p. 95, pl. 18, figs. $5,6$.

Elvinia gregalis Resser, 1942b, p. -97, pl. 18, figs. 28-31.

Elvinia longa Resser, 1942b, p. 97, pl. 18, figs. 24-27.

Elvinia vagans Resser, 1942b, p. 98, pl. 19, figs. 6-9.

Elvinia brevifrons Resser, 1942b, p. 98, pl. 19, figs. 10-14.

Elvinia matheri (Walcott). Shimer and Shrock, 1944, pl. 264, fig. 40.

Diagnosis.-Specimens of Elvinia with smooth external surface of crandium. Brim generally moderately convex; length (sagittal) nearly twice that of border.

Discussion.-This species has been discussed or illustrated perhaps more than any other Upper Cambrian species. Crepicephalus (Loganellus) unisulcatus, described by Hall and Whitfield (1877) from the Eureka district, was shown by Bridge and Girty (1937) to be a synonym of $E$. roemeri. Later, Resser $(1937,1938,1942)$ described many new species of $E l$ vinia. Except for $E$. granulata Resser and $E$. reudemanni Resser, and $E$. hamburgensis (Resser), originally described as Parairvingella hamburgensis (Resser, 1942) and transferred to Elvinia by Kobayashi (1954, p. 34), all other species assigned by Resser to Elvinia are now considered synonyms of $E$. roemeri (Shumard). Frederickson (1949) discussed much of the synonymy, and those species that he did not return to $E$. roemeri are here returned. Elvinia utahensis was used by Resser twice, both times cited as a new species $(1938$, p. $32 ; 1942$, p. 95$)$. Both holotypes are conspecific with $E$. roemeri.

Occurrence: Rare, upper Dunderberg shale (units C, D) and lower part of overlying Windfall formation. USGS colln. 789-CO, 864-CO; 955-CO ; 2302-CO. 789-CO.

Figured specimen: Cranidium, USNM 136851, USGS colln.

\section{Elvinia granulata Resser}

Plate 6, figure 4

Elvina granulata Resser, 1942b, p. 96, pl. 18, figs. 11, 12.

Elvina ruedemanni Resser, 1942b, p. 95, pl. 18, figs. 7-10; Fisher and Hanson, 1951, pl. 1, figs. 1, 2.

?Parairvingella hamburgensis Resser, 1942b, p. 27, pl. 4, figs. 23, 24.

Diagnosis.-Members of Elvinia with external surface of cranidium, exclusive of furrows and palpebral lobes, covered with low granules. Brim generally flat or concave in longitudinal profile, axial length about equal to that of border.
Discussion.-Two species described by Resser (1942), $E$. granulata and $E$. ruedemanni are indistinguishable from each other and represent a distinct species of Elvinia. E. granulata is chosen as the name for the species even though $E$. ruedemanni has page preference (p. 96 vs. p. 95) because its holotype is a much more complete specimen. A third species, Elvinia hamburgensis (Resser) (pl. 6, fig. 5), may also bo conspecific with $E$. granulata, but the granules on the glabella are much broader and have peculiar pologonal outlines. Certain identity cannot be established because too few specimens assignable to $E$. grarulata are known to determine the amount of variability of surface granulation within the species.

Occurrence: Rare, upper Dunderberg shale (unit D), Eureka, Nev.; Galway limestone of Fisher and Hanson (1951), near Saratoga Springs, N.Y.

Figured specimen: Holotype cranidium, USNM 108815, USNM loc. 63.

\section{Elvinia? sp.}

Plate 6, figure 6

A single cranidium from a collection intermediate in stratigraphic position between the known occurrences of Elburgia granulosa (Hall and Whitfield) and Elvinia granulata (Resser) is also intermediate in morphology between the two species and canrot be assigned clearly to either genus. Perhaps, if more material becomes available, it can be shown to represent a new genus intermediate between Elburgia and Elvinia. In any event, this specimen emphasizes the close morphologic relationship of the two genera.

The glabella has three pairs of conspicuous glabellar furrows, the posterior pair connected across the top of the glabella by a shallow furrow, a characteristic feature of the species of Elburgia. The frontal area, the granular surface, and the overall form of the crandium are for the most part like those of Elvinia granulata.

Occurrence: Rare, about $90 \mathrm{ft}$ above base of Dunderberg shale; unit B. USGS colln. 2300-CO.

Figured specimen: Cranídium, USNM 136850.

\section{Genus ELVINIELIA n. gen.}

Type species.-Elviniella laevis Palmer, n. sp.

Diagnosis.-Elviniidae with cranidium bearing conspicuous posterior glabellar furrows conracted across glabella, other glabellar furrows hardly visible. Border and marginal furrow with tendency to come to blunt point on axial line. Fixed cheeks broad. Palpebral lobes long, strongly arcuate; length about onehalf that of glabella including occipital ring. Anterior course of facial sutures nearly straight forward from palpebral lobes.

Other parts of exoskeleton not known. 
Description.-Generally small trilobites probably not exceeding $15 \mathrm{~mm}$ in total length. Cranidium, only known part. Outline, exclusive of posterior limbs, subquadrate; anterior margin tending to come to a blunt point on axial line. Glabella prominent, tapered forward, straight sided, bluntly rounded anteriorly. Width just anterior to occipital furrow slightly less than length exclusive of occipital ring. Only posterior glabellar furrows well defined; deep along flanks of glabella, connected across top of glabella by shallow furrow, not connected to dorsal furrow. Occipital furrow broad, deep; deepest at distal ends. Occipital ring with median node adjacent to occipital furrow. Dorsal furrow broad, deep slong sides of glabella and at anterolateral corners, somewhat shallower across axial line. Border distinct, gently convex, separated from brim by a distinct change in slope and a broad marginal furrow that tends to come to blunt point on the axial line. Brim gently convex; length (sagittal) slightly more than that of border. Fixed cheeks broad, gently to moderately convex, nearly horizontal; width slightly greater than one-half basal glabellar width. Palpebral lobes, long. slender, broadly arcuate, situated slightly below general level of cheek; line connecting anterior tips crosses glabella nearly at anterior margin. Width of palpebral lobes slightly less than onefourth width of cheek; length about one-half length of glabella including occipital ring. Palpebral furrow broad, shallow, well defined. Ocular ridges low, barely apparent. Posterior limbs relatively short, length (transverse) slightly less than basal glabellar width. Marginal furrow of posterior limb broad, deep. Anterior course of facial suture straight forward from palpebral lobe to marginal furrow; turns inward across border and appears to become almost inmediately submarginal. Posterior course divergent sinuous.

Discussion.-This genus is proposed to include nine cranidia from collections in the middle part of the Dunderberg shale. Although more than one species may be represented, only the type species is described because even it is represented by only a few specimens and the significance of the variant forms, represented by single specimens, cannot be certainly determined.

Elviniella most nearly resembles Elvinia among described genera, particularly in the shape of the glabella. It is easily distinguished from Elvinia, however, by the long, slender palpebral lobes and the bluntly pointed anterior margin. The form of the frontal area indicates possible relationships to Dunderbergia and Etburgia and the long palpebral lobes indicate possible affinities with Irvingella. The possible significance of these relationships in the family classification has already been discussed (p. 64).

\section{Elviniella laevis n. sp.}

Plate 6, figures 8-10, 14

Description.-The description presented for the genus covers most of the characteristics of this species. The external surface of the cranidium is virtually smooth; however, whitened specimans observed in oblique lighting show faint irregular anastamosing or reticulate markings on the posterior part of the cheek and terrace lines along the anterior margin of the border.

Discussion.--Two specimens differ from the holotype in features that may be significant. One (pl. 6, fig. 8) has a much more definitely pointed anterior margin, a suggestion of a low median boss on the brim, distinctly roughened cheeks posterior to the midlength of the palpebral lobes, and the posterior glabellar furrow is deepest on the axial line.

The second variant specimen (pl. 6, fig. 14) differs from the holotype by having a distinctly shorter and broader frontal area and by having the line connecting the anterior tips of the palpebral lobes passing slightly anterior to the glabella, thus also giving the ocular ridges the appearance of being directed outward and forward from the anterior end of the glabella.

As both variants occur at about the same stratigraphic level and are each associated with forms virtually like the holotype, they may merely indicate that there is more variation in shape of specimens of this species than in those of such possibly related genera as Dunderbergia and Elvinia.

Occurrence: Rare, 60-150 ft above base of Dunderberg shale; units B, C. USGS colln. 952-CO, 954-CO, 2301-CO.

Figured specimens: Holotype cranidium, USNM 136854, USNM colln. 952-CO; Elviniella sp., USNM 136852, USGS colln. 951-CO ; Elviniella sp., USNM 136853, USTSS colln. 2301$\mathrm{CO}$.

\section{Genus IRVINGELIA Ulrich and Resser, 1924}

Irvingella Ulrich and Resser (in Walcott), 1924, p. 58; Walcott and Resser, 1924, p. 10; Walcott, 1925, p. 97; Resser, 1938, p. 33 ; 1942 b, p. 3, 13; Shimer and Shrock, 1944, p. 627; Kobayashi, 1954, p. 34 .

Irvingella (Parairvingella) Kobayashi, 1938, p. 175.

Parairvingella Resser, 1942b, p. 4, 25.

Irvingella (Irvingellina) Kobayashi, 1938, p. 175.

Type species.-Irvingella major Ulricl and Resser (in Walcott), 1924, p. 58, pl. 10, fig. 3.

Diagnosis.-Elviniidae with prominent subquadrate glabella, broadly rounded anteriorly. Fosterior glabellar furrows connected across glabella, forming single deep furrow; junctions of lateral parts with furrow across top generally slightly angular. Middle pair of glabellar furrows generally visible at sides of glabella. Frontal area short, less than one-fourth length of glabella including occipital ring. Fixed cheeks moderately broad; width between palpebral and 
dorsal furrows slightly more than one-third width of glabella just anterior to occipital furrow. Palpebral lobes long, slender, depressed below general level of cheek; length about two-thirds length of glabella including occipital ring. Posterior limbs short, steeply depressed.

Free cheek narrow. Border broader than ocular platform except posterolateral to eye. Genal spine moderately long, continues curvature of border.

Pygidium subtrapezoidal in outline broadest at or near anterior margin, with prominent axial lobe crossed by 1 or 2 deep ring furrows; length of axial lobe about three-fifths length of pygidium. Distinct border generally present. Pleural lobes narrower than axial lobe.

Discussion.-Historically, Irvingella has been considered a member of the Komaspidae (Kobayashi, 1935, 1954; Hupé, 1953, 1955 ; Lochman, 1954) ; however, the determination of critical features of the Komaspidae is questioned below, and Irvingella is here placed in the Elviniidae. Komaspis typa Kobayashi, the type species of Komaspis and the Komaspidae, is represented by a single poorly preserved cranidium from beds of Middle Cambrian age in Korea. The cranidium is somewhat similar in shape to cranidia of Irvingella (Parairvingella), but nothing is known of the free cheeks or pygidium or of the critical anterior course of the facial suture of this species. Furthermore, nearly all the other species assigned to the Komaspidae are from beds of Late Cambrian age in North America. Because of the poor quality and inadequate knowledge of the morphology of the holotype and only specimen of $K$. typa, its relationships to the North American genera are at best tentative, and the characteristics of the Komaspidae, which must ultimately be based on this specimen are, at least for the present, not determinable.

Ulrich and Resser (in Walcott, 1925) have given an adequate description of Irvingella. Kobayashi (1938) proposed two subgenera, Parairingella and Irvingellina, for forms with a distinct brim and border, and with the front of the glabella overhanging the frontal area, respectively. Resser (1952) raised Parairvingella to generic rank and suppressed Irvingellina as a synonym of Irvingella based on distorted specimens. Westergard (1947) described a species of Irvingella from Sweden showing gradation from forms characteristic of Parairvingella to forms characteristic of Irvingella. Lochman (1953) following Westergard's suggestion has considered Parairvingella a synonym of Iringella. In the Eureka district, forms of Ireingella with brim and border present are found in the uppermost parts of the Dunderberg shale whereas forms without a divided frontal

$5072190-59-\ldots-3$ area are known certainly only from the basal beds of the overlying Windfall formation.

Parairvingella, as a subgenus of Irvingella, is a recognizable taxon apparently occurring in slightly older rocks than the much more widesread Irvingella (Irvingella) species. It is used here in the sense originally intended by Kobayashi.

\section{Subgenus IRVINGELIA (PARAIRVINGELIA) Kobayashi}

Type species.-Chariocephalus? tumifrons Walcott (not Hall and Whitfield) 1884, p. 61, pl. 10, fig. 16 (renamed Irvingella (Parairvingella) angustilimbatus by Kobayashi, 1938, p. 175 .

Diagnosis.-Species of Irvingella with a well-developed border on the adult cranidium.

Discussion.-Two species are recognized within this subgenus. Neither is represented by abundant material, but the differences shown are considered significant.

\section{Irvingella (Parairvingella) angustilimbatus Kobayashi}

Plate 6, figures 2, 3

Chariocephalus? tumifrons Walcott (not Hall and Whitfield) 1884 , p. 61, pl. 18, fig. 16.

Irvingella (Parairvingella) angustilimbatus Kobayashi. 1938, p. 175.

Parairvingella angustilimbatus (Kobayashi), Resser, 1942b, p. 26, pl. 4, figs. 18-22.

Parairvingella intermedia Resser, 1942b, p. 27, pl. 4, figs. 25-31.

Diagnosis.-Members of Parairvingella with axial length of border greater than that of brim; axial length of frontal area on small cranidia (length 7 $\mathrm{mm}$ ) about one-sixth length of glabella not including occipital furrow, axial length of frontal area in larger specimens proportionately greater. Ocular ridges directed nearly straight laterally from anterolateral corners of glabella.

Discussion.-This species is represented by seven cranidia showing the features given in the diagnosis. Resser's statement that brim and border of Parairvingella intermedia are subequal in length is not correct. The border is distinctly longer (sagittal) than the brim, and the species is not distinguishable from $I .(P$.$) angustilimbatus. All the cranidia now$ assigned to this species come from old collentions whose stratigraphic position within the Dunderberg shale is not exactly known. However, the assoriated trilobites indicate that $I .(P$.$) angustilimbatus comes$ from the upper limestone beds of the Dunderberg shale.

Occurrence: Rare, upper part of the Dunderberg shale; unit $\mathrm{D}$.

Figured specimen: Holotype cranidium, USNM 24643, USNM loc. 63. Plesiotype cranidium, USNM 108672, USNM loc. 62 . 
Irvingella (Parairvingella) eurekensis (Resser)

Plate 6, figure 1

Parairvingella eurekensis Resser, 1942b, p. 26, pl, 4, figs. 15-17.

Diagnosis.-Members of Parairvingella with subequally divided frontal area; axial length of frontal area on small cranidia (about $5 \mathrm{~mm}$ ) about one-fourth axial length of glabella exclusive of occipital ring. Ocular ridges directed anterolaterally from anterolateral corners of glabella.

Discussion.-This species is represented by only two cranidia, both from old collections and thus only approximately located stratigrphically within the Dunderberg shale. Both specimens are small, that is, axial length of cranidium less than $5 \mathrm{~mm}$. They might, at first glance, merely seem to represent small specimens of $I$. (P.) angustilimbatus. However, the axial length of the frontal area is proportionately greater than that of the smallest specimen of $I .(P$.$) angustilim-$ batus (cranidial length $7 \mathrm{~mm}$ ). Ontogenetic studies of most ptychoparioid trilobites show that the axial length of the frontal area generally increases with increasing size, and this is apparently true for the seven cranidia assigned to $I .(P$.) angustilimbatus. It therefore seems improbable that the small specimens of $I$. (P.) eurekensis with the relatively long frontal area could be conspecific with $I$. $(P$.) angustilimbatus.

This species shows some similarity to one of the variants of Elviniella laevis n. sp. (pl. 6, fig. 14) from beds slightly lower in the Dunderberg shale. It differs from that specimen, however, principally by lacking the distinctly pointed anterior margin and having a subparallel-sided glabella. The series of forms occurring in apparent stratigraphic succession, beginning with Elviniella Taevis in the middle Dunderberg shale and progressing through the variant just mentioned to Irvingella (Parairvingella) eurekensis and $I .(P$.$) angustilimbatus in the upper beds of the Dun-$ derberg shale, and finally to Irvingella (Irvingella) major in the basal beds of the overlying Windfall formation is suggestive evidence for close genetic relationships between Elviniella and Irvingella (p. 64).

Occurrence: Rare, upper Dunderberg shale: unit D. USGS colln. 789-CO.

Figured specimen: Holotype cranidium, USNM 108668, USNM loc. 61.

\section{Family HOUSIIDAE}

History.-This family name has been used by Hupé $(1953,1955)$ and Lochman (1956) to include only the genus Housia. Two of the genera here proposed, Prehousia and Parahousia, are added to the family and the diagnosis is modified accordingly.

Diagnosis.-Cranidium with glabella tapered forward, well to poorly defined at sides by dorsal fur- row, less well defined across front. Depressions tend to be developed in dorsal furrow at anterolateral corners of glabella. Glabellar furrows weak or absent. Palpebral lobes situated anterior to midlength of glabella and generally close to glabella, poorly defined on external surface. Facial sutures (fig. $8 B, D$ ) intramarginal three-fourths or more distance from anterolateral corners of cranidium to axial line. Rostral suture, if present, nearly marginal. Rostrum apparently present only in older genera; younger genera with median suture across doublure.

Pygidium with length generally less than width. Border broad, poorly defined, of nearly constant width. Axial lobe prominent, tapered posteriorly, generally bears two or more ring furrows; width $1 / 3$ to $1 / 4$ width of pygidium.

Discussion.-The anteriorly situated generally poorly defined palpebral lobes on the cranidium and the border of nearly constant width on the pygidium are the most distinctive characters of members of this family. The other features in the diagnosis are shared to some extent with the Pterocephaliidae, and it is probable that the two families are closely related.

In addition to the genera given above, the following genera or species may also belong to tro Housiidae: Morosa, from the Dunderberg fauna (p. 98); "Aphelaspis" tumifrons Resser, from pre-Dunderberg rocks in eastern Nevada and western Utah and the Maynardville limstone member of the Nolichucky shale in Tennessee; and possibly Acrocephalaspis from the Upper Cambrian of Kazakhstan, Russia (Ivshin, 1956), and Lllaspis from the late Middle Cambrian of Sweden (Westergard, 1948).

\section{Genus HOUSIA Walcott}

Text figure 12

Dolichometopus (Housia) Walcott, 1916, p. 374.

Housia Walcott, 1924, p. 57 ; 1925, p. 93; Shimor and Shrock, 1944, p. 625; Wilson, 1951, p. 642; Lochman, 1956, p. 456.

Type species.-Dolichometopus (Housia) varro Walcott, 1916, p. 37t, pl. 65, figs. 1-1e.

Diagnosis.-Housiidae reaching perhaps $60 \mathrm{~mm}$ in length, with cranidium having brim and anterior part of glabella depressed. Border at a distinct angle to brim; length (sagittal) slightly less than that of brim. Fixed cheek composed almost completely of flaplike palpebral lobe that is situated adjacent to dorsal furrow anterior to midlength of glabella. Doublure of cephalon crossed by median suture.

Free cheek with moderately broad slightly convex border. Lateral and posterior marginal furrows moderately deep, not connected, disappearirg near base of genal spine. Genal spine short or long.

Thorax with 10 to 11 thoracic segments. Axial lobe prominent. Pleural spines short, posteriorly directed. 
Pygidium transversely subovate in outline. Axial lobe prominent, well defined, extends to inner edge of broad, poorly defined border. Border maintains nearly constant width.

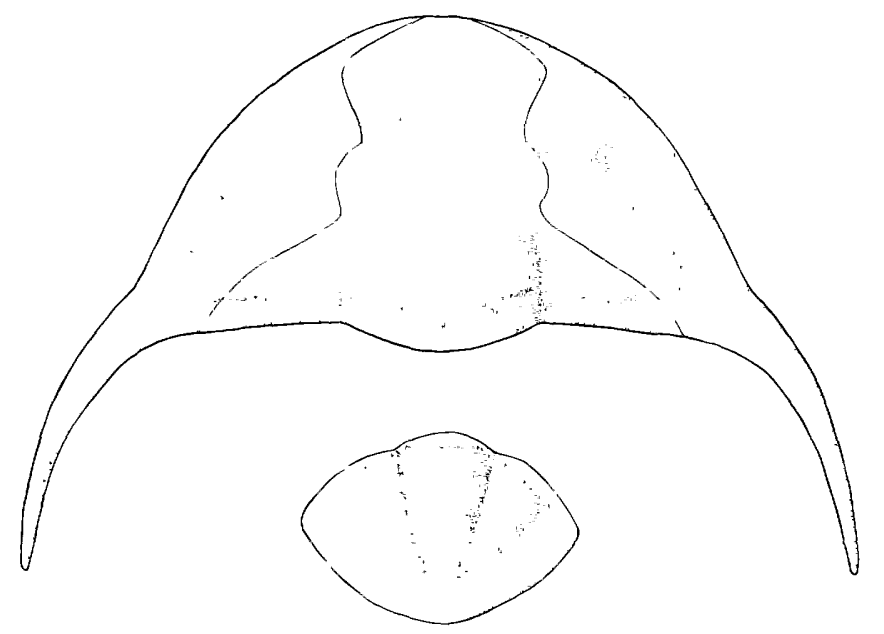

FIgURE 12.--Partial reconstruction of Housia ovata n. sp., about $\times 3$.

Description.-The genus has been well described by Walcott (1925) and Wilson (1951).

Discussion.-Housia is found over most of North America in beds of the Elvinia zone. The depressed brim and anterior part of the glabella and the extremely narrow fixed cheeks of the cranidium are the most distinctive features of the genus. In addition, species of Housia characteristically show unusual variation in the character of the anterior part of the pygidium. Commonly, the last thoracic segment is incompletely separated from the pygidium so that some pygidia have anterolateral spines, some have a thoracic segment developed on one pleural lobe and not on the other ( $\mathrm{pl}$. 7, fig. 6, developed left pleuron broken off), and some pygidia have no anterolateral spines. The retention of the last thoracic segment in the pygidium on some specimens causes a superficial resemblance of this genus to Proceratopyge. Whitehouse (1939) believed that the genera were synonyms. Both Wilson (1951) and Lochman (1956) have given good reasons for considering Housia as a distinct genus perhaps not even closely related to Proceratopyge. An additional and perhaps more important reason than those given by Wilson and Lochman is that the spine-bearing anterior pygidial segment of Proceratopyge is a fundamental part of the pygidium whereas that segment in Honsia is primarily a thoracic segment that has not been detached in normal fashion into the thorax. There is little evidence for or against the suggested relationship of Housia to the asaphidae by Wilson (1951).
Housia halli (Resser)

Plate 7 , figure 8

Crepicephalus (Loganellus) maculosus Hall and Whitfie'd 1877 (part), p. 215, pl. 2, fig. 26.

Dunderbergia halli Resser, 1935, p. 23.

Discussion.-The single pygidium originalle assigned to Crepicephalus (Loganellus) maculosus by Hall and Whitfield and later made the type of a new species in Dunderbergia by Resser represents a species of Housia whose pygidium differs from the pygidium of $H$. ovata $\mathrm{n}$. sp. by being relatively broader and by having a proportionately wider border. It is associated with cranidia of Bynumina globosa (Wolcott) and probably came from limestones near the top of the Dunderberg shale.

The pygidium does not differ significantly from those assigned to $H$. vacuna (Walcott) and $H$. canadensis (Walcott). When cranidia and free chesks of $H$. halli are found, it may prove to be a synonym of 1 of those 2 species.

Occurrence: Rare, uppermost(?) Dunderberg shal:; unit $\mathrm{D}(?)$.

Figured specimen: Holotype pygidium, USNM 90670.

Housia ovata, n. sp.

Plate 7, figures 1-7, 9

Diagnosis.-Members of Housia with free cheeks having gently curved lateral margin and long, slender genal spine. Pygidium with length (sagittal) about two-thirds width. External surface of brim on cephalon, ocular platform of free cheek, and axial lohn and pleural furrows of pygidium coarsely pitted.

Discussion.-Cranidia alone cannot be used satisfactorily for identification of species of Housia; however, the combined features of the cephalon and pygidium of this species distinguish it from the other species in the same genus. H. canadensis (Walcott) and $H$. vacuna (Walcott) have pygidia with length (sagittal) only about one-half width. The free cheeks of $H$. vacuna and $H$. canadensis have short genal spines. The pygidia in the type lot of $H$. varro are distorted, but seem to have a shape intermediate between that of $H$. ucuna and $H$. ovata. The free cheek of $H$. varro has a strongly curved lateral margin. A short genal spine is present on some specimens whereas others seem to lack a genal spine. $H$. halli (Resser) is represented only by a pygidium that may be conspecific with either $H$. canadensis or $H$. vacuna.

Transitory pygidia of $H$. oveate show that retention of partially developed thoracic segments with the pygidium is even more marked in the meraspid stage than in the adult. Several specimens of transitory pygidia in collection 955-CO have 3 to 5 almost completely developed thoracic segments (pl. 7, figs. 4, 9). 
On all of these specimens, the grooves between the anterior segments of the transitory pygidium are less pronounced than those adjacent to the segment that will become the last segment of the thorax. The relatively poor differentiation of the anterior segments on the transitory pygidium is an unusual feature, because these segments are imminent thoracic segments and should be most nearly ready to be detached from the pygidium.

Two features are of importance for indicating the meraspid development of $H$. ovata: the last incipient thoracic segment on each transitory pygidium is distinctly macropleural, and the smallest transitory pygidium (pl. 7, fig. 9) has the greatest number (5) of incipient thoracic segments. The macropleural segment does not advance forward in the incipent thorax, indicating that it is probably truly the last thoracic segment. Thus, adults may also have the last thoracic segment macropleural. It is also probable that the transitory pygidium of meraspid stage 0 has 10 to 11 partially developed thoracic segments fused with the pygidium and that during development these are successively shed forward into the thorax. Similar development has been shown for Macropyge gladiator Ross from the Lower Ordovician (Ross, 1951) and Ceraurinella typa Cooper from the Middle Ordovician (Whittington and Evitt, 1954).

occurrence: Moderately common, about $200 \mathrm{ft}$ or more above base of Dunderberg shale; unit C. USGS colln. 789$\mathrm{CO}, 864-\mathrm{CO}, 872-\mathrm{CO}, 955-\mathrm{CO}$.

Figured specimens: Holotype cranidium, USNM 136863, USGS colln. 872-CO. Paratypes: Free cheek and pygidia, USNM 136864a-c, USGS colln. 872-CO ; cranidium, adult pygidium, and transitory pygidia, USNM 136865a-d, USGS colln. $955-\mathrm{CO}$.

\section{Genus PARAHOUSIa n. gen.}

\section{Text figure 13}

Type species.-Parahousia constricta n. sp.

Diagnosis.-Housiidae with frontal area short; length slightly less than one-half that of glabella. Marginal furrow shallow. Length (sagittal) of border almost twice length of brim. Palpebral lobes prominent, situated close to glabella and anterior to glabellar midlength. Palpebral furrow hardly visible. Fixed cheek narrow; width about one-fifth basal glabellar width.

Free cheek with conspicuous lateral and posterior marginal furrows that disappear near base of long slender genal spine and are not connected.

Pygidium strongly arched in transverse profile. Axial lobe prominent, extended to inmer edge of poorly defined depressed border.

Description.-Generally small trilobites (length probably less than $20 \mathrm{~mm}$ ) with cranidium subtrapezoidal in outline, gently arched transversely and longi-

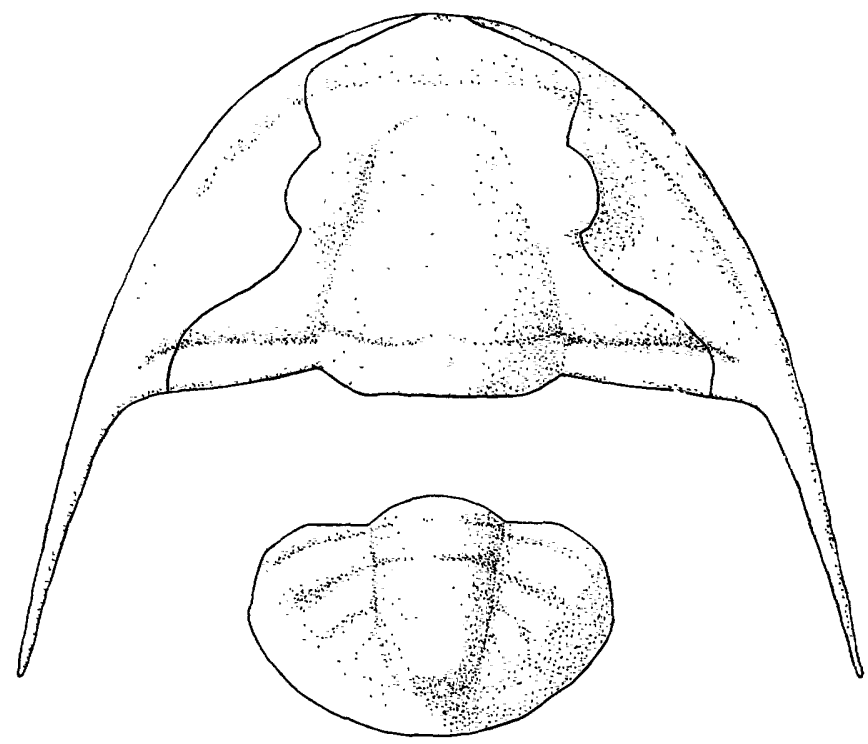

Figdre 13.-Partial reconstruction of Parahousia constricta n. sp., about $\times 8$.

tudinally. Anterior margin bluntly pointed. Glabella well defined by dorsal furrow, tapared strongly forward, slightly constricted between palpebral lobes, bluntly rounded anteriorly. Glabellar furrows hardly visible. Occipital furrow shallow, with sinuous course. Occipital ring broadest on axial line, with low median node. Frontal area short; length slightly less than one-half of glabella. Brim flat. Border slightly convex; length (sagittal) almost twice that of brim. Fixed cheeks narrow; width about one-fifth basal glabellar width. Palpebral furrow hardly visible. Posterior limbs tapered to a blunt tip; lengtl (transverse) slightly less than basal glabellar width. Posterior marginal furrow moderately deep.

Anterior course of facial suture slightly divergent forward from palpebral lobe to marginal furrow, then turned abruptly inward across border to cut anterior margin at axial line. Submargiral course not known.

Free cheek with border, at anterior margin, well defined by moderately deep lateral marcinal furrow; breadth about one-half breadth of ocular platform. Lateral marginal furrow disappears poteriorly near base of genal spine. Posterior marginal furrow moderately deep at junction with posterior limb, disappears laterally near base of genal spine; not connected with lateral marginal furrow. Genal spine moderately long, slender; length slightly less than length (exsagittal) of ocular platform.

Pygidium subsemicircular in outline, moderately to strongly arched transversely. Axial lobe prominent; three shallow ring furrows generally visible. Pleural platforms triangular, gently arched, crossed by 3 or 4 broad shallow pleural furrows that do not extend onto border. Border poorly defined, depressed, broadest at 
anterolateral corners of pygidium, narrowed slightly on axial line. Posterior edge smooth.

Except for border of cheek and muscle scar areas, external surfaces of most parts of cephalon are covered with coarse pits. External surface of axial lobe and pleural platforms on pygidium with hardly visible coarse pits. Border of free cheek, genal spine, and anterolateral corners of pygidium with prominent terrace lines.

Discussion.-This genus is closely related to Housia with which it is associated. It has an almost identical glabellar shape, anteriorly placed palpebral lobes, and nearly identical free cheek. It differs from Housia by having broader fixed cheeks, a less depressed frontal area with proportionately broader border, and less sharply pointed posterior limbs on the cranidium. The pygidium has a depressed rather than nearly horizontal border.

\section{Parahousia constricta n. sp.}

Plate 7 , figures $16-18$

Diagnosis.-This is the only species presently known in Parahousia and its characteristics are described under the genus.

Discussion.-This species is unlike any other species in the Dunderberg fauna. Its present known range is limited to the upper part of the Dunderberg shale.

Occurrence: Moderately common, $190-220 \mathrm{ft}$ above base of Dunderberg shale; unit C. USGS colln. 955-CO, 2302-CO.

Figured specimens: Holotype cranidium, USNM 136870. Paratypes, free cheek and pygidium, USNM 136871a, b. All from USGS colln. 955-CO.

\section{Genus PREHOUSIA n. gen.}

Text figure 14

Type species.-Prehousia alata n. sp.

Diagnosis.-Housiidae with frontal area short; length (sagittal) slightly more than one-half that of glabella. Border well defined, slightly convex; length (sagittal) between $1 / 2$ and $3 / 4$ that of brim. Palpebral lobes scarcely defined by palpebral furrow, situated anterior to glabellar midlength; length (exsagittal) between $1 / 4$ and $1 / 2$ that of glabella. Fixed cheeks narrow; width one-fifth or less basal glabellar width.

Facial sutures cut anterior margin nearly at axial line.

Free cheek with well-defined border. Lateral and posterior margin furrows joined, not noticeably $\mathbf{e x}^{-}$ tended onto base of genal spine. Genal spine slender, tapered to sharp point; length less than greatest length of pleural platform.

Pygidium transversely subovate in outline; breadth greater than twice length. Axial lobe prominent, tapered posteriorly, merged with inner part of bor- der; breadth one-third to slightly less than one-fourth greatest breadth of pygidium. Border moderately broad, separated from pleural platform only by gradual change in slope; maintains nearly constant vidth.

External surface smooth, pitted, or finely granular in axial region.

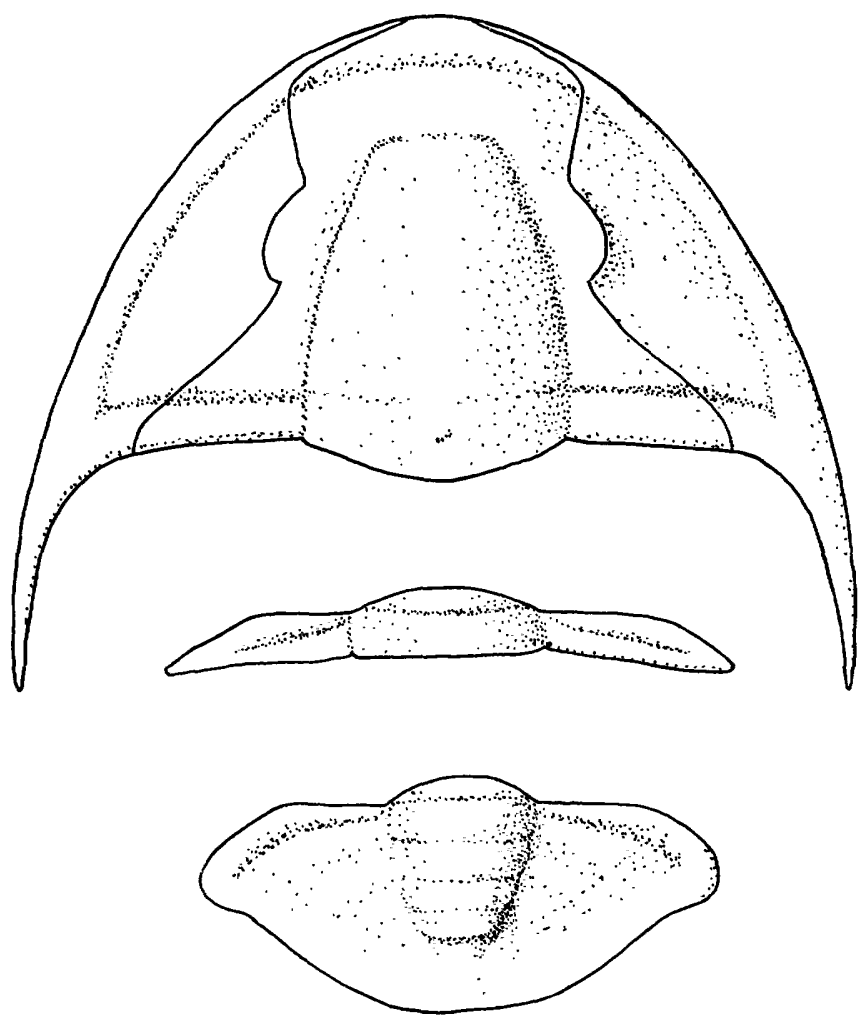

Figure 14.-Partial reconstruction of Prehousia alata n. sp., about $\times 5$.

Description.-Small to medium-sized trilobites (length of largest specimens about $50 \mathrm{~mm}$ ). Cephalon subsemicircular in outline, moderately arched transversely and longitudinally. Cranidium subtrapezoidal in outline with slightly pointed anterior margin. Glabella well defined by shallow dorsal furrow of nearly constant depth; straight sided, tapered forward, bluntly rounded or truncate anteriorly. Glabellar furrows generally not apparent. Occipital furrow shallow, straight. Frontal area divided into distinct brim and border by shallow to moderately deep margin furrow that may develop a slight posterior median inbend or become perceptibly shallower on axial line. Border gently convex; length (sagittal) between $1 / 2$ and $3 / 4$ that of brim, greatest on axial line. Brim gently convex. Fixed cheeks narrow; palpebral lobes hardly defined by palpebral furrow; low ocular ridges may be present. Width of cheek one-fifth or less basal glabellar width. Palpebral lobes situated anterior to glabellar midlength; length (exsagittal) between $1 / 4$ and $1 / 2$ that of glabella; width from onehalf to slightly greater than width of cheek. Posterior limbs elongate triangular in outline; longth 
(transverse) about equal to basal glabellar width; tips bluntly pointed.

Anterior course of facial suture slightly divergent forward from anterior end of palpebral lobe to marginal furrow, then curved sharply onto and across border to cut anterior margin nearly at axial line. Posterior course of facial sutures divergent-sinuous.

Free cheek with gently to moderately curved lateral margin. Genal spine slender, tapered to sharp point; length less than that of ocular platform. Border well defined, gently convex; width at anterior margin of cheek between $1 / 2$ and $3 / 4$ width of ocular platform. Lateral and posterior margin furrows of about equal depth, joined but not extended noticeably onto base of genal spine.

Pygidium transversely subovate in outline. Width greater than twice length. Axial lobe well defined, bears 2 or 3 shallow ring furrows; width from onethird to slightly less than one-fourth greatest width of pygidium; length about two-thirds that of pygidium; posterior end merges with inner part of border. Border differentiated from pleural platforms only by gradual change in slope. Width nearly constant. Pleural platforms crossed by 2 or 3 shallow pleural furrows. Posterior margin smooth.

External surface finely pitted, smooth, or finely granular in axial regions.

Discussion.- This genus is widespread in rocks of latest Dresbach age in the Great Basin. A species of this genus was illustrated as n. gen. aff. Aphelaspis (Palmer and Hazzard, 1956, pl. 1, fig. 3). The type species and another undescribed form occur in the upper part of the Lincoln Peak formation in the southern Snake Range, White Pine County, Nev. (Drewes and Palmer, 1957). The genus is based on the species from the Snake Range rather than on the one from the Eureka district because of the availability of more abundant and better quality material of the Snake Range species.

Prehousia, as its name implies, is related to Housia and occurs consistently in beds older than those bearing species of Housia. The subtrapezoidal shape to the cranidium, palpebral lobes placed anteriorly and close to the glabella, and the pygidium with poorly defined border of nearly constant width all emphasize relationships to Housia. The downsloping rather than depressed frontal area, slightly broader fixed cheeks and straight-sided well-defined glabella all serve to distinguish the genus from Housia. The shape of the glabella, course of the facial sutures, and shape of the pygidium indicate affinities to Aphelaspis. These relationships are the principal reason for considering the Housiidae to be closely related to the Pterocephaliidae of which Aphelaspis apparently is the ancestral genus.
Prehousia differs from Parahousia by having the glabella straight sided rather than constricted between the palpebral lobes, the brim longer (sagittal) than the border on the cranidium, the pygidium transversely subovate in outline rather than subsemicircular, and the border of the pygidium nearly horizontal rather than depressed.

\section{Prehousia alata n. sp.}

Plate 7 , figures $10,12,13$

Diagnosis.-Members of Prehousia with length of border (sagittal) only slightly greater than one-half length of brim. Palpebral lobes short, nerrow; length slightly less than one-third length of glabella; width about one-half width of fixed cheek. Pygidium with tendency for border to develop alae at anterolateral margins. Width of axial lobe nearly one-third width of pygidium. External surface apparently smooth except for low fine granules on axial par ${ }^{4}$ of glabella.

Viscussion.-Specimens of this species are abundant at three localities in the Snake Range, White Pine County, Nev. The species differs from $P$. semicircularis n. sp. by having smaller palpelral lobes, a broader brim, a broader axial lobe on the pygidium, and slightly alate anterolateral pygidial margins.

Occurrence: Common, 130-146 ft below top of Lincoln Peak formation, southern Snake Range, White Pine County, Nev. USGS colln. 1197-CO, 1436-CO, 1441-CO.

Figured specimens: Holotype cranidium, USNM 136866. Paratypes, free cheek and pygidium, USNM 136867a, b. All from USGS colln. 1441-CO.

\section{Prehousia semicircularis n. sp.}

Plate 7 , figures $11,14,15,19$

Diugnosis.-Members of Prehousia with length of border (sagittal) about three-fourths length of brim; palpebral lobes relatively large; length slightly less than one-half that of glabella; width slightly greater than width of fixed cheek. Pygidium with evenly rounded anterolateral corners; width of axial lobe slightly less than one-fourth that of pygidium. External surface smooth on all parts.

Discussion.-The distinctions betweer this species and $P$. alata n. sp. are given in the discussion of $P$. alata.

Occurrence: Moderately rare, lower $20 \mathrm{ft}$ of Dunderberg shale; unit A. USGS colln. 2294-CO.

Figured specimens: Holotype cranidium, USNM 136868. Paratypes, free cheek and pygidia, USNM 136869a-c. All from USGS colln. 2294-CO.

\section{Family OLENIDAE Burmeister}

Henningsmoen (1957, p. 94) gives a detailed discussion of the characteristics of trilobites assignable to this family and points out that the included trilobites 
are so varied that an objective diagnosis is virtually impossible. Most of the features considered essential to an olenid by Henningsmoen (1957, p. 95 ) are present on the trilobites discussed below.

\section{Subfamily OLENINAE}

Diagnosis.—-Olenids with free cheeks with straight spine confluent with course of lateral margin or deviating only very slightly outwards." (Henningsmoen, 1957 , p. 96.)

Discussion.-Two closely related species of olenid trilobites, Olenus? wilsoni Henningsmoen and $O . ?$ granulatus n. sp. are present in the Dunderberg fauna. They differ from typical olenids by having a distinct juncture of the facial suture with the anterior margin of the cranidium and by having only 2 distinct ring furrows and 1 pair of pleural furrows on the pygidium. The cranidial shape, as noted by Henningsmoen (1957, p. 112) for O.? wilsoni, is rather more like Parabolina than Olenus. The free cheek of O.? witsoni, has characteristics more like Olenus than Parabolina. Pygidia of both species have fewer axial and pleural furrows and a slightly less rounded posterior margin than pygidia characteristic of either Olenus or Parabolina. Perhaps the two species here described represent a new olenid genus unknown in the extensively developed olenid faunas of western Europe.

\section{Olenus? wilsoni Henningsmoen}

Text figure 15 ; plate 6 , figures $18,20-22$

Parabolinella incerta (Rasetti). Wilson, 1954, p. 280, pl. 26, figs. 18-22.

Olenus? wilsoni Henningsmoen, 1957, p. 111, text fig. 117.

Diagnosis.-Members of Olenus? with length (sagittal) of frontal area about one-third or slightly more than length of glabella exclusive of occipital ring. Length of border one-half or slightly more than length of brim. Palpebral lobes small, situated anterior to glabellar midlength. Width of fixed cheek slightly less than one-third basal glabellar width. Free cheek with obtuse inner spine angle. Facial suture cuts anterior margin at slight angle at point in front of anterolateral corner of glabella. Pygidium without marginal spines. Length (sagittal) slightly less than one-third width. Axial lobe with one ring furrow; pleural lobes with one pleural furrow. External surfaces of all parts smooth.

Discussion.-This species differs from all known Olenus species in the combination of features given in the diagnosis. It is most similar to O..? granulatus n. sp., differing primarily by having a smooth rather than granular surface on the cranidium.

Occurrence: Moderately rare, $30-90 \mathrm{ft}$ above base of Dunderberg shale; units A, B. UsGS colln. 2295-CO(?), 2296CO. 2297-CO, 2299-CO, 2300-CO.

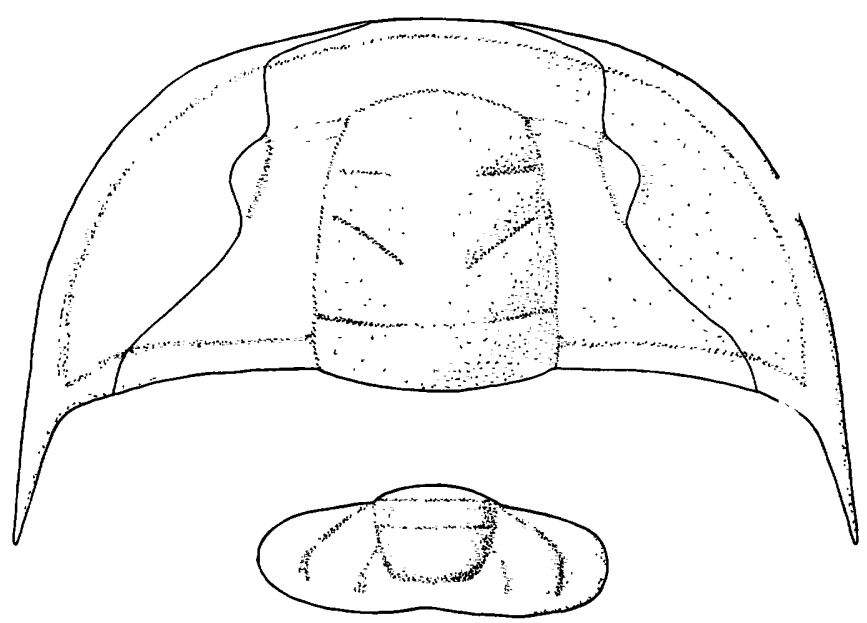

FIgURE 15.-Partial reconstruction of olenus? wilsoni Henningsmoen, about $\times 12$.

Figured specimens: Plesiotypes-cranidia and pygidium, USNM 136858a, b, USGS colln. 2300-CO; cranidium ard free cheek, USNM 136859a, b, USGS colln. 2297-CO.

\section{Olenus? granulatus n. sp.}

Plate 6, figures 23-27

Diagnosis.-Members of Olenus? with length (sagittal) of frontal area about one-third length of glabella exclusive of occipital ring. Length (sagittal) of border slightly more than one-half length of brim. Palpebral lobes small, situated anterior to glabellar midlength. Width of cheek slightly more than onefourth basal glabellar width. External surface of most of cranidium covered with fine granules.

Pygidium transversely subovate in outline. Length about one-third width. Axial lobe prominent, bearing distinct articulating furrow and one ring furrow; subquadrate in outline; length about three-fourths that of pygidium. Pleural lobes nearly flat, crossed by one deep furrow diverging backward from anterior margin. Border narrow, poorly defined, not crossad by pleural furrow. Lateral margin of pygidium sharply rounded. Posterior margin gently curved away from pygidium from lateral margin to point behind dorsal furrow, then gently curved towards pygidium to axial line producing a distinct angulation on margin directly behind dorsal furrows on each side of axial lobe. External surface covered with low fine granules.

Discussion.-This species differs from all described species of Olenus by having a granular external surface. The transverse pygidium with only one ring furrow distinguishes it from all species except $O . ?$ vilsoni Henningsmoen.

Occurrence: Moderately rare, $70-90 \mathrm{ft}$ above base of Dunderberg shale; unit B. USGS colln. 795-CO, 2299-CO, 2300co.

Figured specimens: Holotype cranidium, USNM 136861, USGS colln. 2300-CO. Paratypes: Cranidium, USNM 136862, 
USGS colln. 795-CO; pygidium, USNM 136860, USGS colln. 2299-CO.

\section{Family PTEROCEPHALIIDAE}

History.-Contents of a taxon bearing this name have been discussed by only two authors. Kobayashi (1935, p. 230) proposed the Pterocephaliinae as a subfamily of the Ptychopariidae. As in the Elviniidae, the genera grouped by Kobayashi seem to have little real relationship. Lochman $(1956$, p. 458,459$)$ presented a new combination of genera under this name that includes many of the trilobites grouped here in the subfamilies Aphelaspidinae and Pterocephaliinae. No statement of the family characteristics of the Pterocephaliidae was given by Lochman, however; it is not possible, therefore, to determine her grounds for the family grouping.

Diagnosis.-CThe Pterocephaliidae as used here includes genera that share, in addition to stratigraphic and geographic continuity, the following distinguishing morphologic features: Cranidium with glabella tapered forward, generally well defined at sides and anterolateral corners by dorsal furrows, anterior end less well defined; glabellar furrows generally poorly defined-when distinct, generally broad, rarely, if ever, deep and narrow; dorsal furrows with tendency to develop depressions at anterolateral corners of glabella; border generally moderately broad and with breadth distinctly greater than distance from upper surface to lower surface of doublure; palpebral lobes generally well defined, subcentrally located; posterior limbs slender, sharply pointed. Facial sutures intramarginal three-fourths or more distance from anterolateral corners of cranidium to axial line (fig. $8 \mathrm{~A}, E$ ). Rostral suture, if present, nearly marginal. Rostrum apparently present only in older genera; most younger genera with median suture across doublure. Pygidium with broad border and doublure; width of axial lobe generally one-fourth or less that of pygidium; two or more ring furrows generally present; border poorly defined, generally noticeably narrower on axial line.

Disrussion.--Of the features listed above, the shape of the cranidium posterior to the front of the glabella and the course of the facial suture have been of primary importance in relating the genera of the Pterocephaliidae. Few North American genera from beds older than the Aphelaspis zone or younger than the Elvinia zone and few genera of any age outside North America have a glabellar shape of the type described above. Pterocephalops (Rasetti, 1944) from a boulder in the Levis conglomerate in eastern United States, Maladioidella from the Upper Cambrian of Manchuria, and Nericia from the late Middle Cambrian of Sweden-genera not known from the Great Basin-are most likely to be representatives of this family. Grönwallia from the late Middle Cambrian of Sweden may also belong to the Pterocephaliidae.

The Pterocephaliidae of this study are grouped into two subfamilies, the Aphelaspidinae and Pterocephaliinae, that are distinguished primarily $c n$ characteristics of the border of the cranidium anc secondarily on characteristics of the pygidium and free cheeks. Whether these taxa represent families or subfamilies is an unanswerable question. 'They are here considered as subfamilies to emphasize their many common features that seem to show real genetic relationships, while still permitting recognition of the distinctive features that separate the generic goupings.

\section{Subfamily APHELASPIDINAE n. subf mily}

Diagnosis.-Pterocephaliid trilobites with border on cephalon well-defined, commonly conver; less commonly flat or slightly concave. Pygidium with border subequal in width to greatest width of pleural platform.

Discussion.-This subfamily includes the American genera Aphelaspis, Labiostria, Litocephalus, and Taenora, and possibly also Maladioidella from the Upper Cambrian of Manchuria. Nericia as represented by its type species, $N$. quinquedentata Westergard from the late Middle Cambrian of Sweden, has a cranidium strikingly similar to that of Labiostria, but differs in having relatively smallor palpebral lobes. The pygidium has a much narrower border than any of the species of the Aphelaspidinae. Nericia septemdentata Westergard, also from the late Middle Cambrian of Sweden, has a frontal area on the cranidium and border on the cheek much like Pterocephatia, but an entirely different pygidium. Although the species assigned to Nericia seem referable to the Pterocephaliidae, they do not seem to belong to either of the subfamilies here described.

Labiostria as originally constituted (Palmer, 1954), included three species, the type species. L. conveximarginatus, L. platifrons, and L. sigmoidalis. $L$. platifrons is tentatively assigned here to Taenora. $\mathbf{n}$. gen., and $L$. sigmoidalis, with its concave cranidial border, is removed from both the genus and the subfamily and related to sigmocheilus n. gen. in the Pterocephaliinae.

Aphelaspis, the oldest genus in the subfamily, represents perhaps the root stock of both the Aphelaspidinae and Pterocephaliinae. Althougl its cephalic border is distinct, it lacks the well-defined marginal furrow characteristic of the other genera in the subfamily. The pygidium also is relatively smaller and has fewer segments than pygidia in the younger genera.

Litocephalus and Taenora, as elements of the Dunderberg fauna, are discussed below. 
Trilobites of the Aphelaspidinae are the dominant elements of the trilobite faunas of the Aphelaspis zone. In the Dunderbergia and Elvinia zones, they are subordinate in numbers of species to trilobites of the Pterocephaliinae and Elviniidae.

\section{Genus IITOCEPHALUS Resser, 1937}

Text figure 16

Litocephalus Resser, 1937, p. 17; Palmer, 1956a, p. 608. Pterocephalina Resser, 1938, p. 42.

Type species.-Dicellocephalus richmondensis Walcott, 1884, p. 41, pl. 10, fig. 7 (=Dikellocephalus bilobatus Hall and Whitfield, 1877, p. 226, pl. 2, fig. 36).

Daignosis.-Aphelaspidinae with cephalon having border well defined by deep marginal furrow. Thorax with pleural spines of most segments long, slender, backwardly directed. Pygidium with border concave; posterior margin with deep median notch reaching nearly to posterior end of axial lobe.

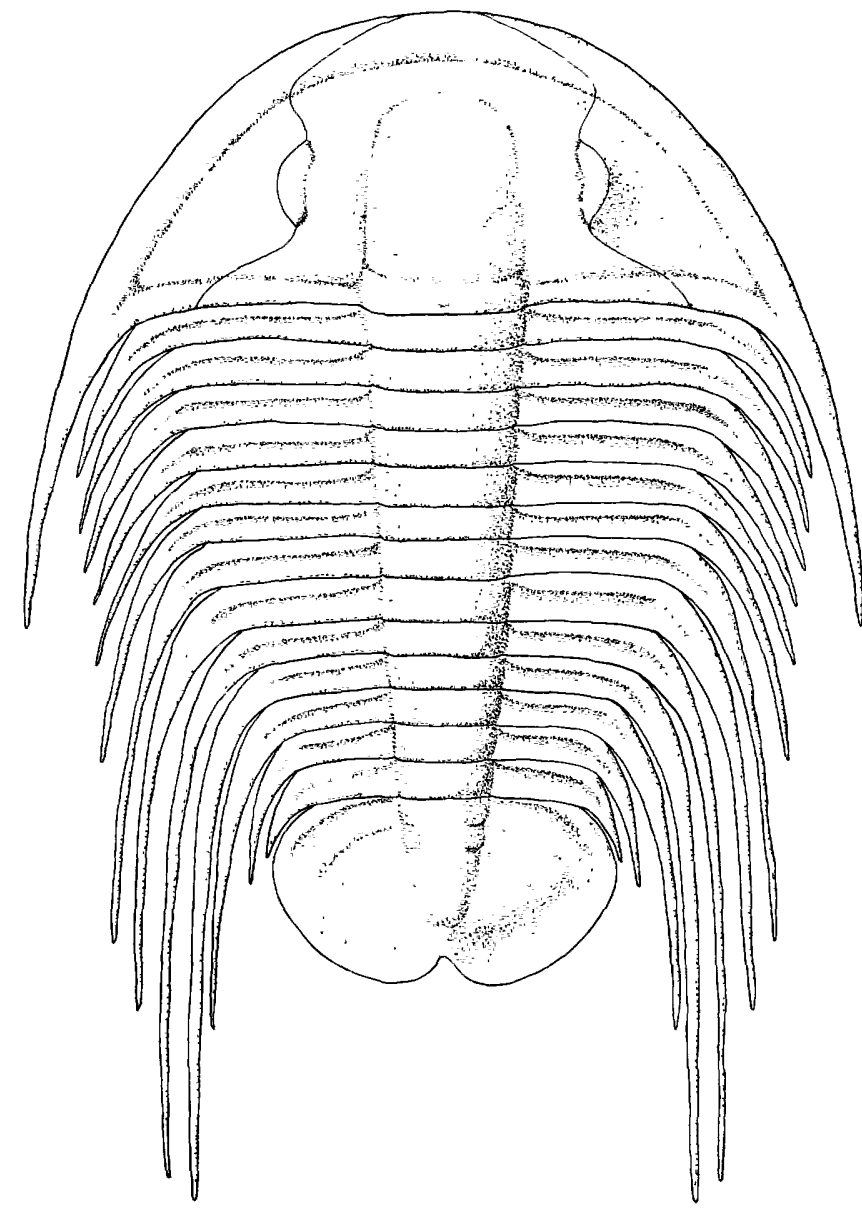

Figure 16.-Reconstruction of Litocephalus bilobatus (Hall and Whitfield), about $\times 2$.

Description.-Medium to large trilobites (up to about $85 \mathrm{~mm}$ in length) with exoskeleton elongate subovate in outline; widest about on line through occipital ring. Cephalon subsemicircular in outline with prominent posteriorly directed genal spines.

Cranidium, exclusive of posterior limbs, elongate rectangular in outline, moderately arched transversely and longitudinally, moderately to strongly rounded at anterior margin. Glabella distinct, well defined, straight sided, tapered slightly forward, bluntly rounded or truncate anteriorly; commonly featureless, though traces of three pairs of slightly arcuate glabellar furrows may be seen on exfoliated specimens. Dorsal furrows deepest along side and at anteroJateral corners of glabella, shallow on midline. Occipital ring with small median node. Occipital furrow moderately shallow, straight. Brim and border present, separated by a narrow marginal furrow. Brir flat. Border in profile arched up sharply from marginal furrow, then gently arched or flat to anterior margin; length (sagittal) from slightly more than one-half to about equal that of brim. Fixed cheeks nearly flat, slightly upsloping; width about one-third basal glabellar width. Palpebral lobes arcuate in form, moderately well defined by shallow palpebral furrow. Ocular ridges generally distinct. Posterior limbs narrow, sharp pointed; length (transverse) about equal to basal glabellar width.

Facial sutures diverge slightly to moderately forward from palpebral lobes until reaching marginal furrow, turn sharply inward to cut anterior margin near point directly in front of anterolateral corners of glabella, and continue submarginal nearly tc axial line where they curve sharply backward across doublure outlining edge of triangular or subtrapezoidal rostrum. Posterior course divergent-sinuous.

Hypostome elongate subovate in outline, strongly arched transversely and longitudinally. Anterolateral corners extended into short depressed pointed alae. Border narrow, distinct, present only along sides. Anterior lobe of central body not clearly differentiated from posterior lobe.

Free cheek with long, slender, sharply pointed anterior projection resulting from partly intramarginal anterior course of facial suture. Border sep`rated from ocular platform by a narrow marginal furrow; profile similar to that on border of cranidium. Lateral and posterior marginal furrows of about equal depth; they join at genal angle and extend for a short distance onto genal spine as a shallow pointed depression. Infraocular ring present between eye surface and ocular platform.

Thorax probably composed of 13 segments. Axial lobe distinct, elevated above nearly flat pleural lobes. Pleural furrow of each segment broad, shallcw, located at, or slightly anterior to, midlength (ersaggital) of segment, not extended to thoracic tip. Pleu- 
ral spines on all but perhaps last two thoracic segments are long, slender, turned sharply backward from proximal portion of pleuron; length about equal to width (transverse) of proximal portion.

Pygidium wide, short, much smaller than cephalon. Axial lobe prominent, elevated above pleural platforms; 4 or 5 distinct axial rings and a bluntly pointed terminal part present; posterior margin of first segment distinctly separated on medial line from fused part of articulating half ring of second segment. Pleural platforms gently arched, downsloping; broad, shallow pleural furrows of 4 or 5 segments present, extending nearly across border. Border slightly concave, greatest width about equal to that of pleural platform; inner margin marked by narrow shallow straight furrow extending from tip of axial lobe to anterolateral corner of pygidium; lateral margin a broad curve extending from anterolateral corner of pygidium to base of prominent posterior medial notch near tip of axial lobe.

Discussion.-Litocephalus is a distinctive genus characterized principally by the combination of a well-defined border and deep marginal furrow on the cephalon and by a deep median notch in the posterior margin of the pygidium. Three species of the genus are here recognized, based principally on consistent differences in the external surface of the cephalic border. The species have short and apparently mutually exclusive stratigraphic ranges within that of the genus.

\section{Litocephalus bilobatus (Hall and Whitfield)}

Plate 7, figures 24-27

Dikellocephalus bilobatus Hall and Whitfield, 1877, p. 226, pl. 2' fig. 36.

Dicellocephalus richmondensis Walcott, 1884, p. 41, pl. 10, fig. 7. Litocephalus richmondensis (Walcott). Resser, 1937, p. 17.

Pterocephalina bilobata (Hall and Whitfield). Resser, 1942b, p. 77 , pl. 14 , figs. $39-43$.

Litocephalus bilobatus (Hall and Whitfield). Palmer, 1956a, p. 608-610, pl. 73, figs. 1-6, 8 .

Diagnosis.-Members of Litocephalus with cranidium and free cheek having external surface of border smooth. Length (sagittal) of border about three-fourths that of brim. Facial sutures cut anterior margin between point directly in front of anterolateral corners of glabella and axial line. Pygidium with surface of axial rings smooth.

Discussion.-The type lot of Litocephalus bilobatus comes from an unknown stratigraphic position within the Dunderberg shale and contains only pygidia of this species. Study of the Dunderberg shale fauna shows that 3 species of Litorephalus are present, and, for 2 of these, isolated pygidia cannot be certainly distinguished. Furthermore, pygidia of these two species are not distinguishable from the type of $L$. bilobatus. Fortunately, on the same pieces of rock with the type pygidium and its counterpart, specimens of Morosa longispina n. sp. and Dunderbergia variagranula Palmer are present. Only 1 of the 2 species of Litocephalus in the stratigraphically controlled collections is associated with $M$. longispina and I. variagranula, and that one is here considered as $L$. bilobatus. This indicates that $L$. bilobatus comes from the lower part of the Dunderberg shale in the Eureka district rather than from the upper part as stated earlier (Palmer, 1956a, p. 610). The conclusion is supported by the association of the specimens illustrated in 1956 (op. cit.) with Dunderbergia polybothra n. sp., known from only 1 collention in the measured section about 40 feet above the base of the Dunderberg shale.

Cranidia of L. bilobatus are disting uished from those of $L$. verruculapeza n. sp. and L. granulomarginatus $\mathrm{n}$. sp. by having a smooth external surface on the border. They are further distinguished from $L$. verruculapeza by having relatively large palpebral lobes. Pygidia of L. bilobatus cannot be distinguished with certainty from those of $L$. granulomarginatus, but lack the paired granules on each axial ring that characterize pygidia of $L$. vermeulapeza.

Occurrence: Common, 50-70 ft above base of Dunderberg shale; unit B. USGS colln. 809-CO, 2297-CO, 2298-CO.

Figured specimens: Plesiotypes, cranidium, free cheek, pygidium, and thoracic segment, USNM 128324a. b, d, e, USGS colln. 1297-CO.

\section{Litocephalus granulomarginatus n. sp.}

Plate 8 , figures 14, 17, 18, 24

Diagnosis.-Members of Litocephalus with cranidium having border moderately arched in longitudinal profile and covered with low fine granules. Border of cheek also covered with low fine granules. Length of border (sagittal) slightly less than three-fourths length of brim. Length of palpebral lobes about onehalf length of glabella exclusive of occipital ring. Facial suture cuts anterior margin between point directly in front of anterolateral corners of glabella and axial line. Pygidium with surface of axial rings smooth.

Discussion.-Except for the fine-granular border on the cephalon, this species is like L. bilobatus (Hall and Whitfield). The larger palpebral lobes and the absence of scattered coarse granules on the border of the cranidium and the absence of paired granules on the axial rings of the pygidium distinguish this species from $L$. verruculapeza $\mathrm{n}$. $\mathrm{sp}$.

Occurrence: Rare, $80-100 \mathrm{ft}$ above base of Dunderberg shale; unit B. USGS colln. $795-\mathrm{CO}, 2300-\mathrm{CO}$.

Figured specimens: Holotype cranidium, USNM 136883, UNCAS colln. 795-CO. Paratypes, pygidium ard free cheek, USNM 136884a, b, USGS colln. 2300-CO. 
Iitocephalus verruculapeza n. sp.

Plate 8 , figures $12,13,15,16,19,20$

Diagnosis.-Specimens of Litocephalus with cranidium having border nearly equal in length to brim, flattened in profile, and bearing scattered coarse granules. Palpebral lobes small, situated about opposite second glabellar furrow; length about one-third or less that of glabella exclusive of occipital ring. Facial suture cuts anterior margin almost directly in front of anterolateral comers of glabella. Pygidium with pair of coarse granules on each of first four axial rings.

Discussion.-The small palpebral lobes, the scattered coarse granules on the border of the cranidium, and the paired granules on the axial rings of the pygidium distinguish this species from the other known species of Litocephalus.

Occurrence: Moderately rare, $70-80 \mathrm{ft}$ above base of Dunderberg shale; unit B. USGS colln. 2299-CO.

Figured specimens: Holotype cranidium, USNM 136881. Paratypes, cranidium, pygidia, and free cheeks, USNM 136882 a-e. All from USGS colln. 2299-CO.

\section{Genus TAENORA n. gen.}

\section{Text figure 17}

Type species.-Taenora expansa $\mathrm{n}$. sp.

Diagnosis.-A Aphelaspidinae with cranidium having well-defined flat or slightly concave border of nearly constant breadth. Fixed cheeks flat, horizontal, width less than one-third basal glabellar width. Anterior course of facial suture moderately divergent forward from palpebral lobe to marginal furrow, intramarginal along most of anterior margin, cuts anterior margin nearly imperceptibly near axial line.

Free cheek with moderately broad flat or slightly concave border; lateral and posterior marginal furrows joined at base of genal spine, extended for short distance onto spine. Genal spine relatively short; length less than that of ocular platform. Pygidium transversely subovate in shape with poorly defined flat or concave border, with or without slight median indentation. Axial lobe prominent, merged posteriorly with inner part of border. All furrows on pygidium shallow.

Description.-Medium to large trilobites (up to about $70 \mathrm{~mm}$ in length). Cranidium gently to moderately arched transversely and longitudinally, broadly rounded anteriorly. Glabella well defined at sides and anterolateral corners by shallow dorsal furrow, poorly defined across front; straight sided, tapered forward, bluntly rounded anteriorly. Three pairs of shallow glabellar furrows may be visible; posterior pair bigeniculate and on some specimens also bifurcate forming $Y$-shape with posterior branch of $Y$ most

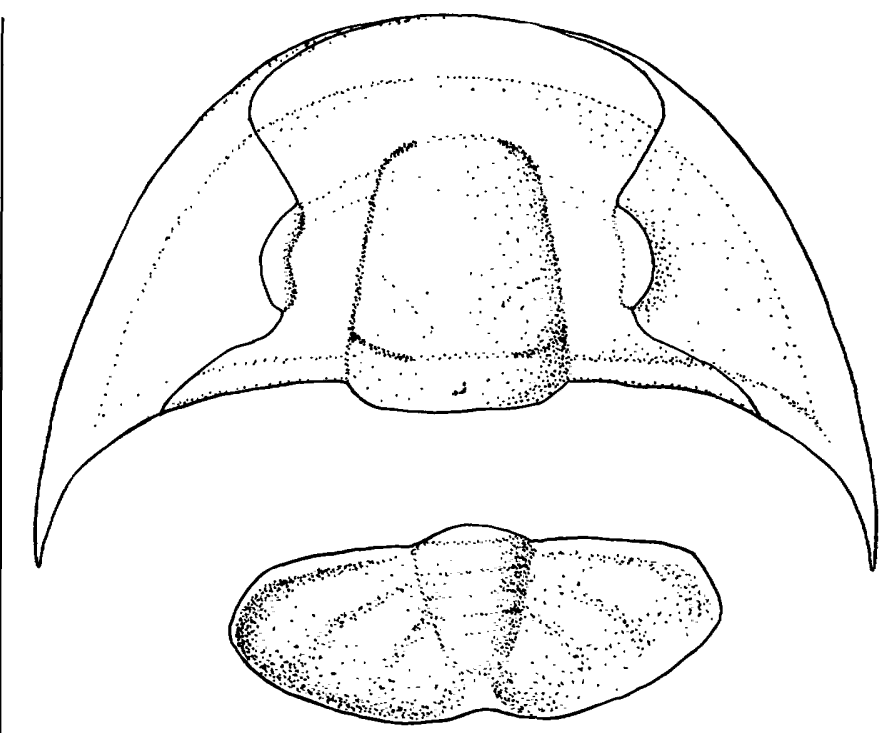

Figdre 17.-Partial reconstruction of Taenora expansa n. sp., about $\times 3$.

deeply impressed; anterior pairs of glabellar furrows straight. Occipital furrow moderately deep, straight, shallowest on axial line. Occipital ring gently arched (sagittally), with small median axial node. Frontal area divided into well-defined brim and border by shallow evenly curved marginal furrow. Border broad, flat, or slightly concave near anterior margin, horizontal or slightly downsloping, of nearly constant breadth. Brim flat or gently convex; length (sagittal) about equal to or less than that of border. Fixed cheeks flat, horizontal; width about $1 / 3$ to $1 / 4$ basal glabellar width. Distinct ocular ridges present. Palpebral lobes well defined by shallow palpebral furrows, situated opposite or slightly posterior to midlength of glabella; length (exsagittal) $1 / 2$ to $1 / 3$ length of glabella. Width about one-half width of fixed cheek. Posterior limbs slender, tapered to sharp point; length (transverse) about equal to basal glabellar width.

Anterior course of facial suture divergent forward from anterior end of palpebral lobe to marginal furrow, then curved slightly inward and crossing border nearly to anterior margin; intramarginal from that point nearly to axial line. Junction with arterior margin hardly noticeable. Posterior course divergentsinuous.

Free cheek with gently convex lateral margin; genal spine short, flattened in cross section, trpered rapidly to sharp point; length less than that of ocular platform. Lateral and posterior marginal furrows joined and extended slightly onto base of genal spine.

Pygidium transversely subovate in outline with prominent axial lobe bearing 2 or 3 shallow ring furrows. Axial lobe tapered posteriorly, merged with 
inner part of border or with poorly defined ridge that extends to margin; length slightly more than threefourths length of pygidium. Border flat or slightly concave, poorly defined; may have distinct median indentation. Pleural platforms with 2 or 3 shallow pleural furrows.

External surfaces of all known parts smooth.

Discussion.-The most distinctive feature of trilobites of this genus is the form of the border on the cranidium. Taenora differs from Labiostria, which is here restricted to forms with a convex cranidial border like that of $L$. conveximarginatus Palmer, and Litocephalus by having a flat or slightly concave somewhat downsloping border of nearly constant breadth on the cranidium. The fact that trilobites with this sort of border differ in relative breadth of border, size of palpebral lobes, impression of glabellar furrows, shape of genal part of free cheek and of posterior margin of pygidium indicates that the flat border may be a subfamily rather than a generic character. Until more species of this type are known, they are being included in the Aphelaspidinae.

Labiostria platifrons Palmer from the Upper Cambrian of central Texas is tentatively referred to this genus.

Taenora expansa n. sp.

Plate 7, figures 20-23

Diagnosis.-Members of Taenora with length (sagittal) of border almost twice that of brim. Palpebral lobes relatively short, about one-third length of glabella. Glabella with moderately well defined glabellar furrows, posterior pair on many specimens Y-shaped. Free cheek with border moderately broad, well defined, distinctly narrowed near base of genal spine. Pygidium short, wide; with distinct median indentation.

Discussion.-This species differs from all other species in the fauna by having a nearly flat cranidial border of almost constant width and approximately horizontal fixed cheeks. The relatively wide border on the cranidium, shape of the genal part of the free cheek, and median indentation in the pygidium distinguish this species from T.P platifrons (Palmer). Two fragmentary cranidia, one each from USGS collections $795-\mathrm{CO}$ and 2298-CO seem to belong to Taemore but cannot certainly be assigned to this species.

Occurrence: Rare, $70(?)-150 \mathrm{ft}$ above base of Irunderberg shale; units $\mathrm{B}($ ?), C. USGs colln. 954-CO, 2301-CO, ?795-CO, ?2298-CO.

Figured specimens: Holotype crandium, USNM 136872, USGS colln. 954-CO. Paratypes: Pygidium, USNM 136874, USGS colln. 954-CO; cranidium and free cheek, USNM 136873 a, b, USGS colln. 2301-CO.

\section{Subfamily PTEROCEPHALIINAE}

Diagnosis.-Pterocephaliid trilobites with border of cranidium generally broad, concave, and longer (sagittal) than brim. Border of free cheok generally broad, concave. Pygidium with broad, poorly defined border on most species.

Discussion.-This subfamily includes at present only the North American genera Pterocephatia, Cemuolimbus, and sigmocheilus. Similar foreign trilobites that may have some affinities with this subfamily are Nericiu septemdentata Westergard (p. 89) from the late Middle Cambrian of Sweden, and poscibly Dikelocephalites flabelliformis Sun, from the Upper Cambrian of China. The latter species is too poorly known, however, for adequate determiration of its systematic position. Anechocephalus n. gen. (p. 92) may also belong to this subfamily.

Pterocephalinid trilobites are distinctive elements of the Dunderberg fauna and its correlatives over most of the Great Basin. They are not known from beds older than the post-Aphelaspis zone nor younger than the Elivinia zone.

\section{Genus CERNUOLIMBUS n. gen.}

Text figure 18

Type species.-Cernuolimbus orygmatos Palmer n. sp.

Diagnosis.-Pterocephaliinae with cranidium having distinct brim and border; axial length of border equal to or slightly greater than axial length of brim; border generally downsloping. Anterior branches of facial suture cut anterior margin at distinct angle at a point slightly more than three-fourth distance from anterolateral corner of cranidium to axial line.

Free cheek with long genal spine and well-defined generally concave border. Lateral marginal furrow continuous with posterior marginal furrow. Breadth of border varies from one-fourth to slightly less than greatest breadth of ocular platform.

Pygidium subovate to subsemicircular in outline; axial lobe reaching more than three-fourths total axial length of pygidium, bearing 2 to 5 distinct ring furrows. Pleurae with 2 to + low pleural ribs extending nearly to margin. Border not clearly differentiated from pleural platform, concave, widest at anterolateral corners, tapers gradually posteriorly, narrowest on axial line.

Description.-Medium-sized trilobites (probably averaging $40 \mathrm{~mm}$ or less in total length) with cephalon subsemicircular in outline, moderately arched transversely and longitudinally, bearing long genal spines extending nearly straight back from posterolateral corners. Border well defined by shallow margi- 


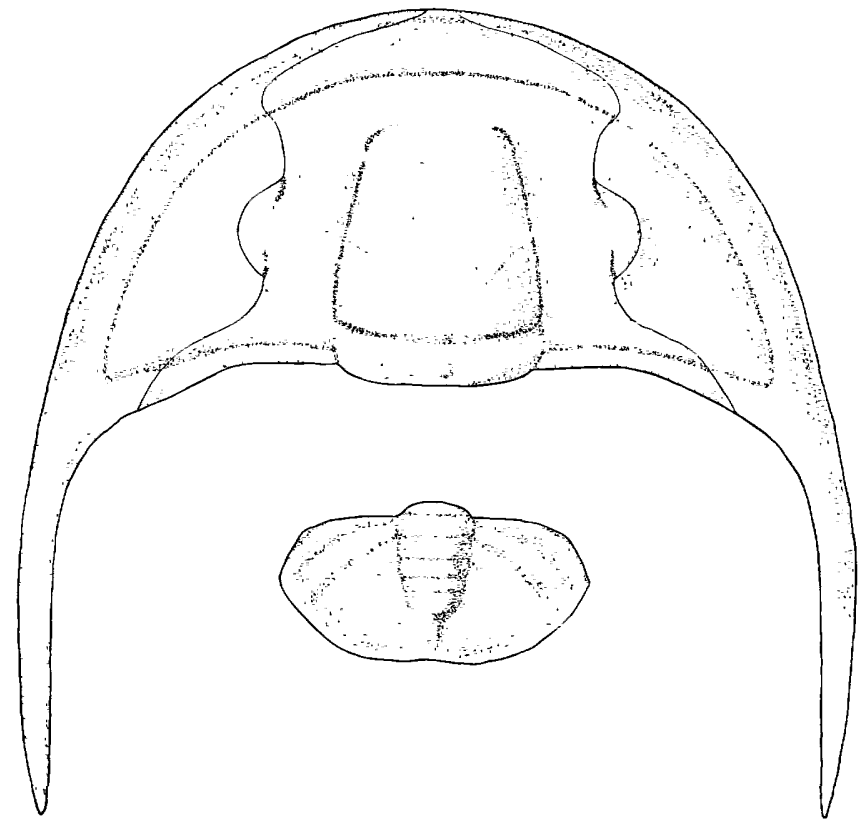

FIgURE 18.-Partial reconstruction of Cernuolimbus orygmatos $\mathrm{n}$. sp., about $\times 4$.

nal furrow. Eyes prominent, at or slightly below level of top of glabella.

Cranidium with somewhat pointed anterior margin resulting from facial sutures cutting margin at a distinct angle near the axial line. Glabella well defined, straight sided, tapered slightly forward, bluntly rounded or truncate anteriorly. Glabellar furrows hardly visible. Occipital furrow straight, moderately deep. Occipital ring with low median node. Dorsal furrows deep at sides and anterolateral corners of glabella, shallow across front. Frontal area subequally divided into brim and border, or with border slightly longer (sagittal) than brim. Border downsloping, with anterior margin slightly flexed upward; flexure distinctly anterior to midlength (sagittal) of border. Brim gently arched in longitudinal profile. Fixed cheeks upsloping from dorsal furrow; width between palpebral and dorsal furrows slightly less than one-half basal glabellar width. Ocular ridges moderately well defined, directed obliquely backward from slightly behind anterolateral corners of glabella. Palpebral lobes prominent, well defined by shallow arcuate palpebral furrow; width about one-half width of cheek between dorsal and palpebral furrows; length ahout one-half length of glabella exclusive of occipital ring. Posterior limbs slender, sharply pointed; length (transverse) about equal to basal glabellar width. Anterior course of facial suture slightly divergent from anterior end of palpebral lobe to marginal furrow, then turned diagonally inward and forward across border to cut anterior margin slightly more than three-fourths distance from anterolateral corner of cranidium to axial line. Posterior course divergent-sinuous.

Free cheek with long, slender genal spine continuing curvature of margin. Border well defined, generally concave. Lateral and posterior marginal furrows connected but not continuous posterolaterally onto genal spine.

Pygidium with axial lobe prominent, narrow, tapered posteriorly, bearing 2 to 5 distinct ring furrows. Length about three-fourths axial length of pygidium. Pleurae with 1 to 4 low pleural ridges extending nearly to margin. Border not clearly defined, concave, widest at anterolateral corner, tapered backward to axial line.

Hypostome, rostrum, and thoracic segments not known.

Discussion.-This genus seems to be ancestral to Pterocephalia and sigmocheilus. Cranidia can be most easily recognized by their pointed anterior margin and flat or slightly arched downsloping border that is only slightly longer (sagittal) than the brim. The free cheeks have the lateral and posterior marginal furrows characteristically connected and not extending onto the genal spine. Pygidia are most easily recognized by the combined features of an evenly rounded posterior margin and a border that is relatively narrower than that of other genera in the subfamily.

\section{Cernuolimbus depressus n. sp.}

Plate 8, figures 9, 10

Diagnosis.-Members of Cernuolimbus with external surface of cranidium coarsely pitted; border downsloping, continuing slope of brim, tapered to a point laterally. Facial sutures nearly meeting on axial line giving pointed anterior margin to cranidium. Marginal furrow on mold bears single row of granules.

Discussion.-This species is represented by four cranidia. No other parts are known. The character of the border is the most striking feature that distinguishes it from $C$. orygmatos n. sp. and C. semigranulosus n. sp.

Occurrence: Rare, $50-60 \mathrm{ft}$ above base of Dunderberg shale; unit B. USGS colln. 2297-CO.

Figured specimens: Holotype cranidium, USNM 136879. Paratype cranidium, USNM 136880. Both from USGS colln. $2297-\mathrm{CO}$.

\section{Cernuolimbus orygmatos n. sp.}

Plate 8 , figures $1,3,5,8,11$

Diagnosis.-Members of Cernuolimbus with external surfaces of all parts coarsely pitted. Border of cranidium slightly downsloping from marginal furrow, nearly flat or slightly turned up at anterior margin. Pygidium with subsemicircular outline; 4 well- 
defined ring furrows; anterior 4 or 5 axial rings each bear a pair of coarse granules.

Discussion.-The distinctive coarse pitted surface serves to distinguish this species from C. semigranulosus n. sp. It differs from $C$. depressus n. sp. by having a relatively longer frontal area and less-pronounced lateral taper to the border of the cranidium.

Occurrence: Common, 30-50 ft above base of Dunderberg shale; units A, B. USGS colln. 2295-CO, 2296-CO.

Figured specimens: Holotype cranidium, USNM 136875. Paratypes, free cheek and pygidia, USNM 1368i6a-c. All from USGS colln. 2295-CO.

\section{Cernuolimbus semigranulosus n. sp.}

Plate 8 , figures $2,4,6,7$

Diagnosis.-Members of Cernuolimbus with border nearly flat or slightly turned up at anterior margin; generally downsloping from marginal furrow. External surface of cranidium smooth except for tops of palpebral lobes and glabella which are thickly covered with small granules. Free cheek with closespaced fine granules on genal spine; breadth of border equal to or only slightly less than greatest breadth of ocular platform. Pygidium transverse in outline with scattered barely visible fine granules over most of surface. Axial lobe with two moderately well defined ring furrows.

Discussion.--This species differs from both CernuoTimbus depressus n. sp. and C. orygmatos n. sp. by having a fine-granular rather than coarse-pitted surface ornament. It differs further from $C$. depressus by having a much less laterally tapered and downsloping border on the cranidium, and from C. orygmatos by having a relatively wide border on the free cheek. The pygidium of $C$. semigranulosus lacks the distinct granules on the axial rings characteristic of C. orygmatos, and also has only 2 rather than 4 or 5 distinct ring furrows. Its outline is proportionately shorter and wider than that of $C$. orygmatos.

Occurrence: Moderately common, lower $20 \mathrm{ft}$ of Dunderherg shale; unit A. USGS colln. 2294-CO.

Figured specimens: Holotype cranidium, USNM 136877. Paratypes, pygidium and free cheek, USNM 136878a, b. All from USGS colln. 2294-CO.

\section{Genus PTEROCEPHAIIA Roemer, 1849}

Text figure 19

Pterocpehalia Roemer, 1849, p. 421; 1852, p. 92; Bridge in Bridge and Girty, 1937, p. 247; Shimer and Shrock, 1944, p. 631 ; Palmer, 1954, p. 751.

T'ype species.-Pterocephalia sanctisabae Roemer, 1849 , p. 421.

Diagnosis.-Pterocephaliinae with cranidium having border broad, concave, scarcely differentiated from brim. Length of border (sagittal) greater than three times length of brim. Junction of facial sutures with anterior margin generally imperceptible. Facial sutures submarginal beneath part of anterior margin to axial line, then turn abruptly backward to form median suture across doublure.

Free cheek with broad concave bordor, slightly raised above level of ocular platform it marginal furrow. A low ridge parallels entire lateral margin nearly to tip of genal spine at distance about onefourth width of border from lateral margin. Genal spine moderately long, broad and flat at base, tapered to sharp slender point.

Some thoracic segments with long broad backswept pleural tips.

Pygidium subquadrate to subovate in outline with well-defined axial lobe bearing 4 to 8 visible ring furrows. Border not differentiated from pleural platform gently arched, crossed by 3 to 5 pleural ridges that extend onto but not across border. Border broad, concave, with slight to moderate median indentation. Edge smooth.

External surface of exoskeleton generally with close-spaced fine granules in axial region. Borders of cranidium, free cheek and pygidium, and tips of pleurae of thorax generally with prominent terrace lines.

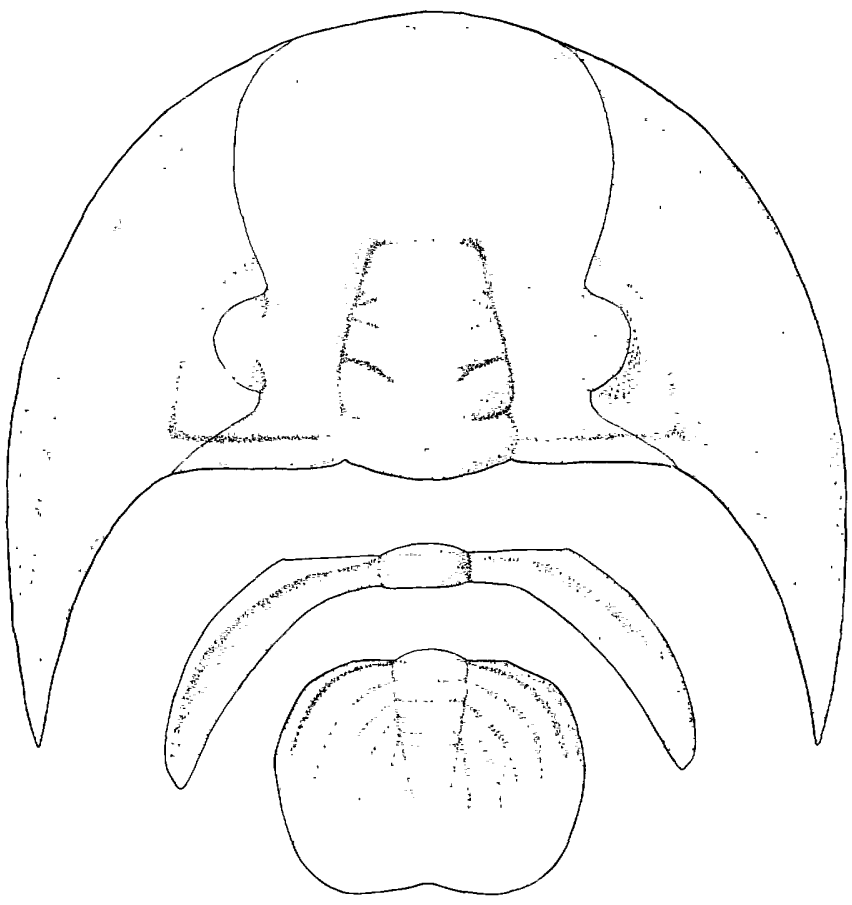

Figure 19.-Partial reconstruction of Pterocephalis sanctisabae Roemer, about $\times 2$.

Description.-Medium to large trilobites (length up to about $70 \mathrm{~mm}$ ) with large cephalon and pygidium. Cephalon with broad slightly conave border scarcely differentiated from brim on cranidium, with inner margin slightly raised above ocular platform 
on free cheek. Length of border (sagittal) on cranidium is greater than 3 and up to 9 times that of brim. Low ridge present on border of nearly all free cheeks and many cranidia parallel to and about one-fourth breadth of border from margin. Genal spines broad, flattened, tapered to a sharp point. Glabella straight sided, tapered forward, truncate to bluntly rounded anteriorly, generally less than one-half length (sagittal) of cranidium. Dorsal furrows deep at sides and anterolateral corners of glabella, shallow across front. Three pairs of moderately deep glabellar furrows present on some species. Occipital furrow straight, deep adjacent to dorsal furrow, shallow across axial line. Occipital ring with low median node. Fixed cheeks broad, upsloping from dorsal furrows; width about one-half basal glabellar width. Ocular ridges generally well developed. Palpebral lobes moderately long, curved, midlength situated slightly posterior to midlength of glabella; length (exsagittal) about onehalf length (sagittal) of glabella; breadth (transverse) nearly one-half breadth of fixed cheek. Palpebral furrow moderately deep, arcuate. Posterior limbs slender; length (transverse) slightly greater than basal glabellar width.

Anterior course of facial suture slightly to moderately divergent forward from palpebral lobe until onto border, then curved broadly across border to cut anterior margin-nearly imperceptibly and continue submarginally to axial line where it turns abruptly backward as median suture across doublure. Posterior course of facial suture divergent, sinuous.

Entire thorax not known. Some thoracic segments with long broad pleural spines directed posteriorly.

Pygidium with elongate subquadrate to transversely subovate outline. Axial lobe well defined, tapered posteriorly to a blunt point at inner edge of broad border, generally continued across border as a narrow ridge. Four to eight ring furrows visible. Pleurae not clearly divided into border and pleural platform. Pleural platform generally slightly arched, crossed by 3 to 5 well-defined pleural ridges. Border broad, slightly concave; broadest posterior and posterolateral to tip of axial lobe. Margin with slight to moderate median indentation. Edge smooth.

External surfaces of border of cephalon, distal parts of thoracic pleurae, and border of pygidium generally with well-developed terrace lines. Axial region of exoskeleton generally with close-spaced fine granules. Scattered large granules on the border may be present or absent within a suite of cranidia of a single species.

Hypostome not known.

Discussion.-Bridge (1937, p. 246-250) discussed Pterocephalia and the species included in the genus to that time. He recognized three species, $P$. sanctisabae
Roemer, $P$. asiatica (Walcott), and $P$. occidens Walcott. Kobayashi (1936), unknown to Bridgo, had placed $P$. asiatica in Paracoosia. The types of this species are incomplete. The cranidium shows prominent bumps on the fixed cheeks adjacent to the dorsal furrow and just anterior to its junction with the occipital furrow. The pygidium has short broad spines along the margin. These features are here considered sufficient to exclude asiatica from Pterocephalia.

Resser (1938) placed specimens of $P$. sanctisabae illustrated by Bridge from various localities in the United States in 9 species of which 7 were new. On the basis of material from Oklahoma, Frederickson (1949) placed three of Resser's species in synonymy with $P$. sanctisabae. Lochman (1950) grouped three more of Resser's species together under the name $P$. bridgei and considered this species distinguishable from $P$. sanctisabae by having a proportionately shorter frontal area on the cranidium. Wilson (1951), though not mentioning Resser's 1938 paper, included all the specimens illustrated by Bridge (1937) in the synonymy of $P$. sanctisabae, thus implying that all the species recognized by Resser in 1938 are syronyms of $P$. sanctisabae.

Part of the confusion in the taxonomy of specimens assigned to Pterocephalia results from this fact that specimens well-enough preserved to study are relatively rare, and few collections have sufficient individuals to permit adequate determination of infraspecific variation in the cranidial proportions that have been used for specific differentiation. Thus, Lochman's recognition of two species of Pterocephalia based solely on differing proportions between the length (sagittal) of the frontal area and the length of the glabella has an inadequate statistical basis. All the types and topotypes of the species of Pterocephalia recognized by Resser (1938) and reg"ouped by Lochman have been examined in the course of this study. For all the cranidia under $15 \mathrm{~mm}$ in length, no significant differences are observable in the length of the frontal area compared to the length of the glabella. Only 6 cranidia longer than $15 \mathrm{~mm}$ are present. These are distributed among four of the species recognized by Resser and include a cranidium of $P$. bridgei. Although there is variation in the relative lengths of the frontal areas compared to glabella lengths from slightly less than $1.5: 1$ to $2: 1$, and specimens representing $P$. bridgei and $P$. sanctisabae are nearly at opposite extremes, no sample has more than 2 of the large cranidia and determination of the significance of the variation in the proportion cited is not possible. Comparison of the variation of cranidial characters with size in Cambrian trilobites indicates that there is more apparent variation among larger specimens than among smaller sperimens 
(Palmer, 1958). Until more is known of the variation of cranidial proportions within a single population of $P$. sanctisabae, the characterization of $P$. bridge $i$ by Lochman is considered inadequate for its separation from $P$. sanctisabae and all species of Pterocephalia listed by Resser (1938) are here considered synonyms of $P$. sanctisabae.

$P$. occidens Walcott is represented by a single small exfoliated cranidium (pl. 9, fig. 21) from an unknown level within the Dunderberg shale. It could represent either $P$. concava n. sp. or $P$. elongata n. $\mathrm{sp}$. Because of this, the species is here considered to be indeterminate and the name should be restricted to the holotype.

Pterocephalia cf. P. occidens from Texas (Palmer, 1954 ) is more like $P$. concava n. sp. than any of the other species of Pterocephalia here recognized and should now be designated Pterocephatia cf. P. concav'a Palmer.

\section{Pterocephalia concava n. sp.}

Plate 9, figures 1-6, 9-12

?Pterocephalia cf. P. occidens Walcott, Palmer, 1954, p. 752, pl. 86, figs. 9,10 ; pl. 87 , figs. $1,2$.

Diagnosis.-Specimens of Pterocephatia with shallow glabellar furrows. Border of cranidium and free cheek generally with low scattered coarse granules. Length (sagittal) of border increases from 3 to greater than 5 times that of brim from small $(4-5 \mathrm{~mm}$ long) to large (14 $\mathrm{mm}$ long) mature cranidia.

Some thoracic segments, perhaps all, with long broad flattened backwardly directed pleural tips. Breadth (transverse) of pleural tips greater than breadth (exsagittal) of proximal part of pleuron.

Pygidium transversely subovate in outline, with slight median inbend in posterior margin. Axial lobe with 4 to 5 distinct ring furrows. Pleural lobes crossed by 2 or 3 distinct pleural ridges. Breadth of border increases relative to breadth of pleural platform, and border becomes more concave with increasing size.

Discussion.-This species, which occurs in preElvinia zone beds, is most similar to $P$. sanctisabae from the Elvinia zone. It differs principally by having less conspicuous glabellar furrows, fewer distinct ring furrows and pleural ridges on the pygidium, and a strikingly different development of the mature specimens. Small mature specimens of $P$. concana (cranidial length $4-5 \mathrm{~mm}$ ) are similar to forms of compparable size in Cernuolimbus and Sigmocheilus, differing principally in the absence of clear distinction between the brim and border. Large specimens resemble $P$. sanctisabae. Small mature specimens of $P$. sanctisubae, however, look virtually like the large specimens of $P$. sanctisabae (cf. pl. 9, figs. 1, 3, 4, 7). The change in form of mature specimens of $P$. con- cav' $a$ with increasing size emphasizes the relationships of Pterocephatia to Cernuolimbus and Sigmocheilus. The comparative mature development of $P$. concava and $P$. sanctisabae may be strong evidenc indicating that $P$. concava is one of the earliest species of Pterocephatia.

$P$. concava differs from $P$. elongata n. sp. primarily by having a transverse rather than elongate subquadrate form to the pygidium and by having a less well-marked median indentation of the posterior margin.

Occurrence: Moderately common, $50-60 \mathrm{ft}$ above base of Dunderberg shale; unit B. USGS colln. 809-CO, 2297-CO. Specimens are questionably assigned to this species from USGS colln. 795-CO.

Figured specimens: Holotype cranidium, CSNM 136887. USGS colln. 2297-CO. Paratypes: Cranidia, USNM 136888a-c; free cheek, USNM 136888e; pygidia, USNM 136898d, $\mathrm{f}-\mathrm{h}$; thoracic segment, USNB 136\$s\$i. All from USGS

\section{Pterocephalia elongata n. sp. \\ Plate 9, figures 14-20}

Diagnosis.-Members of Pterocephalia with shallow glabellar furrows. Length (sagittal) of border between 3 and 5 times length of brim.

Pygidium with elongate subquadrate outline. Greatest breadth near posterior margin. Sides straight, nearly parallel or slightly diverging posteriorly. Posterior margin nearly straight, with slight median indentation.

Axial lobe with 4 or 5 distinct ring furrows. Junction of lateral and posterior margins strongly rounded. Two or three distinct pleural ridges parallel lateral margin of pygidium. A narrow ridge continues posteriorly from tip of axial lobe across border to posterior margin.

Hypostome and thoracic segments not known.

Discussion.-The shape of the pygidium of this species is its most distinctive feature. Isolated cranidia and free cheeks cannot be distinguished with certainty from those of $P$. concava. Tho cranidium of $P$. elongata differs from that of $P$. sanctisabae by having less conspicuous glabellar furrows, a somewhat more concave border, and a straighter posterior margin.

occurrence: Moderately common, $80-100 \mathrm{ft}$ above base of Dunderberg shale; unit B. USGs colln. 873-CO, 2300-CO.

Figured specimens: Holotype cranidium, USNM 136891. USGS colln. 873-CO. Paratypes: Pygidium, TISNM 136892, USGS colln. 873-CO; cranidium, free cheeks, and pygidia, USNM 136893a-c, USGS colln. 2300-CO.

\section{Pterocephalia sanctisabae Roeme*}

Plate 9, figures 7, 8, 13

Pterocephalia sanctisabae Roemer, 1849, , p. $421 ; 1852$, p. 92, pl. 11, figs. 1 a-d; Bridge, 1933, p. 232, pl. 2, figs. 26, 27; 
Kobayasni, 1936, p. 172, pl. 21, figs. 10-12; Bridge, in Bridge and Girty, 1937, p. 246 , pl. 67 , figs. $1 \mathrm{a}-\mathrm{d}$; pl. 68 , figs. 7-43; Shimer and Shrock, 1944, pl. 266, figs. 35-37; Wilson, 1949 , p. 42, pl. 10, figs. 1-3; Frederickson, 1949, p. 355, pl. 69, figs. 1-4; (?) Wilson, 1951, p. 647, pl. 91, fig. 24.

Conocephalites (Pterocephalus) laticeps Hall and Whitfield, 1877, p. 221 , pl. 2 , figs. $4-7$.

Dikellocephalus multicinctus Hall and Whitfield, 1877, p. 226, pl. 2, fig. 37.

Pterocephalia dakotensis Resser, 1938, p. 39.

Pterocephalia bridgei Resser, 1938, p. 40; Lochman, 1950, p. 334 , pl. 47 , figs. $14-18$.

Pterocephalia oriens Resser, 1938, p. 40.

Pterocephalia potosiensis Resser, 1938, p. 40.

Pterocephalia ulrichi Resser, 1938, p. 41.

Pterocephalia silvestris Resser, 1938, p. 41.

Pterocephalia deckeri Resser, 1938, p. 41.

Diagnosis.-Members of Pterocephatia with moderately deep glabellar furrows. Length (sagittal) of border on cranidium between 5 and 9 times length of brim on mature specimens.

Free cheek with breadth of border four or more times breadth of ocular platform at anterior margin.

Pygidium transversely subovate in outline, with at least 6 distinct ring furrows on axial lobe and with 4 or 5 distinct pleural ridges on pleural lobes: Posterior' margin with slight median indentation.

Discussion.-This species is a distinctive element of the Elrinia fauna over most of the United States. Its complicated nomenclatural history has been reviewed in the discussion of the genus. The extremely broad border on the cephalon, conspicuous glabellar furrows, and the many conspicuous ring furrows and pleural ridges on the pygidium are the distinctive specific features.

Occurrence: Rare, $140 \mathrm{ft}$ or more above base of Dunderberg shale: unit C. USGS colln. 2301-CO, 2302-CO.

Figured specimens: Plesiotypes-cranidium and free cheek, USNM 136889a, b, USGS colln. 2302-CO; pygidium, USNM 136890, USGS colln. 2301-CO.

\section{Genus SIGMOCHEILUS n. gen.}

Text figure 20

Type species.—Sigmocheitus serratus n. sp.

Diagnosis.-Pterocephaliinae with generally welldefined border on cranidium. Length of border (sagittal) between 1.5 and 3 times greater than that of brin. Border generally concave in profile with greatest depth near its midlength (sagittal). Facial sutures cut anterior margin at slight angle between point opposite anterolateral corners of glabella and axial line.

Free cheeks with long genal spine and well-defined concare border. Lateral and posterior marginal furrows barely connected. Lateral marginal furrow shallowest; posterior marginal furrow continues onto genal spine. Breadth of border less than greatest breadth of ocular platform.
Pygidium subquadrate to transversely subovate in outline, greatest width about opposite posterior end of axial lobe. Axial lobe prominent, bears 4 or 5 ring furrows; tapered to a blunt point at inner edge of border. Border and pleural platform not clearly differentiated: 3 to 5 pleural ridges generally apparent. geniculated at boundary between pleural platform and border. Lines comnecting geniculations roughly outline triangular pleural platforms. Pleural ridges continued onto but not across border. Border concave, posterior margin evenly rounded, nearly straight, or with slight median indentation. Edge smooth or with short broad spines.

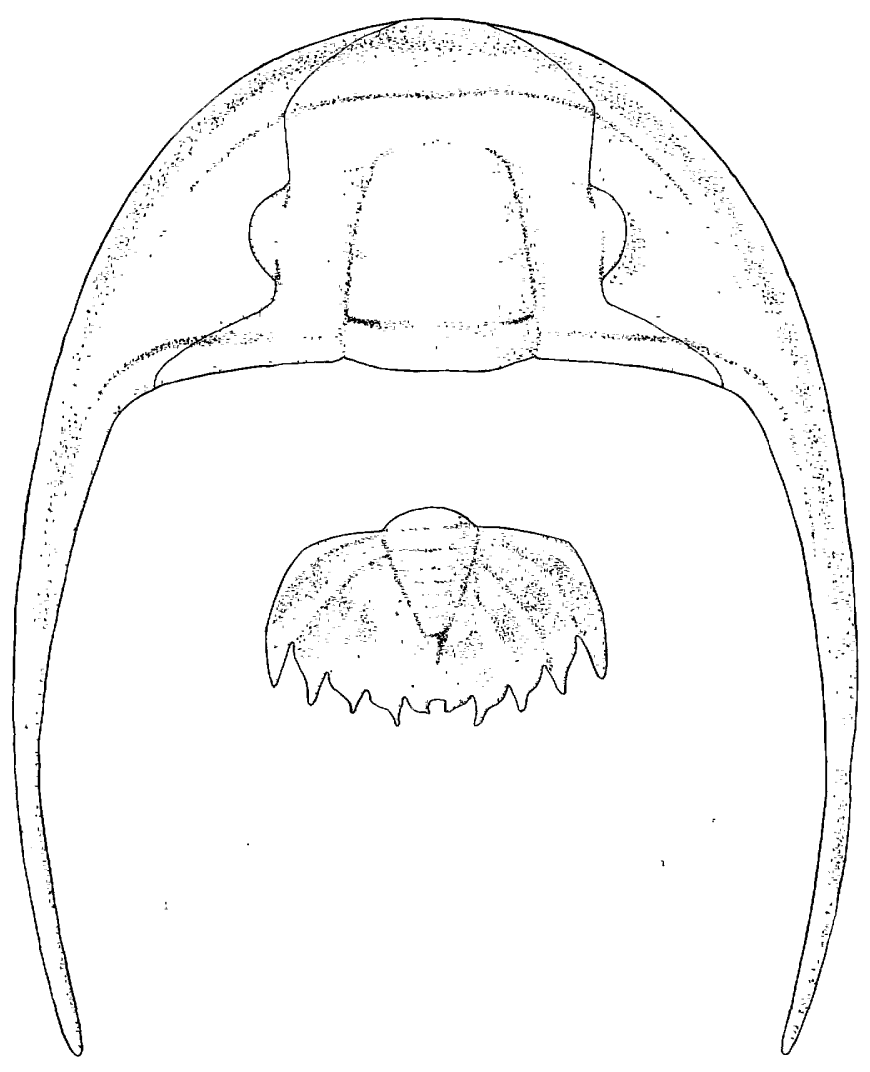

FigURE 20.-Partial reconstruction of Sigmocheilus serratus, n. sp.. about $\times 3$.

Description.-Medium-sized trilobites (probably averaging $40 \mathrm{~mm}$ or less in length) with cephalon subsemicircular in outline, 'moderately arched transversely and longitudihally, bearing' long genal spines extending nearly straight back from posterolateral corners. Border well-defined to poorly defined on cranidium and on free cheek by shallow marginal furrow. Lateral marginal furrow barely comnected to posterior marginal furrow. Eyes prominent, at or slightly below level of top of glabella.

Cranidium with anterior margin evenly rounderd. Glabella well-defined, dorsal furrow deep at sides and 
anterolateral corners, shallow across bluntly rounded front. Glabellar furrows shallow, posterior pair bigeniculate to slightly $Y$-shaped with posterior arm of $Y$ most strongly dereloped. Occipital furrow straight, deepest adjacent to dorsal furrow. Occipital ring with low median node centrally located. Border concave in longitudinal profile, deepest part of concavity near midlength (sagittal). Length (sagittal) of border 1.5 to 3 times that of brim. Marginal furrow shallow; junction between brim and border generally marked by contrast between strong reination or granulation of brim and nearly smooth surface of border. Inner margin of border sometimes slightly raised above adjacent brim surface. Fixed cheeks horizontal or upsloping. Ocular ridges low, extending backward to palpebral lobe from a point slightly posterior to anterolateral corners of glabella. Width of fixed cheek slightly more than one-third basal glabellar width. Palpebral lobes well defined by arcuate palpebral furrow; width about two-fifths width of fixed cheek; length between $2 / 5$ and $1 / 2$ length of glabella. Posterior limb slender, sharply pointed; length (transverse) slightly less than basal glabellar width. Anterior course of facial suture slightly divergent forward from palpebral lobe onto border, then curved sharply inward across border to cut anterior margin between a point directly anterior to anterolateral corner of glabella and axial line; suture then submarginal to axial line and turned backward across doublure as median suture. Rostrum apparently absent. Posterior course of facial suture divergentsinuous.

Free cheek with long tapered genal spine. Border concave, well-defined to poorly defined along lateral margin by marginal furrow; breadth slightly less than greatest breadth of ocular platform. Shallow lateral marginal furrow not clearly connected to deep posterior marginal furrow.

Pygidium with axial lobe prominent, narrow, tapered posteriorly to inner edge of border; 4 or 5 ring furrows generally visible; length (sagittal) between $1 / 2$ and $3 / 4$ length of pygidium. Pleurae with 3 to 5 low pleural ridges extending laterally across poorly defined pleural platform and then turning backward onto, but not across, border at an angle of between $30^{\circ}$ to $45^{\circ}$ with axial line. Border concave. Posterior margin broadly rounded, nearly straight, or with slight median indentation. Edges smooth or with short broad spines.

Hypostome and thoracic segments not known.

External surface of cranidium generally partly covered with low small granules. External surfaces of other parts smooth or granular. Surface of molds of all parts smooth.
Discusxion.-Species of this genus are most likely to be confused with those of Cernuolimbus or early forms of Pterocephalia. Cranidia can be most easily recognized by a distinct concave border that is up to 3 times longer (sagittal) than the brim. Free cheeks are characterized principally by having the border concave and narrower than the ocular platform. Pygidia of $\$$. grata and $S$. utahensis resemble those of early species of Pterocephatia and can only be certainly assigned to Sigmocheilus when they are associated with the characteristic cranidium. Later pygidia with scalloped or spinose margins are distinctive of sigmocheilus.

Resser (1942, p. 76-79) included in a genus Pterocephalinu four new species, $P$. texana, $P$. notha, $P$. pogonipenis, and $P$. grata besides the type species, $P$. bilobata (Hall and Whitfield). Pterorephatina has since been shown to be a synonym of Litocephalus. and P. bilobata to be properly Litorephalus bilobatus (Palmer, 1956a). Of the remaining species, all but P. terana belong to sigmocheilus.

$P$. texana was stated to come from the Wilberns formation (Resser, 1942, p. 77) in Texas. An insoluble residue of a part of the limestone riece bearing the holotype pygidium contained Angulotreta triangularis Palmer, and fragmentary specimens of Aphelaspis are present adjacent to the pygidium. These associated fossils show that the holotype came from the Aphelaspis zone of the Riley formation. The pygidium is probably that of a species of Labiostria.

Wilson (195t, p. 271) figured two fragmentary cranidia and referred them to Pterocephatina cf. $P$. grata Resser. These cranidia represent an indeterminate species of Sigmocheitus.

Iddingsia? quinnensis Resser (1942, p. 88, pl. 16, figs. 39-41) is known only from cranidia. It definitely represents a species of Sigmocheilus, but its relationships to the species here described will not be known until its pygidium is described.

\section{Sigmocheilus grata (Resser)}

Plate 9, figures $22,23,26,27$

Pterocephalina grata Resser, 1942b, p. 78, pl. 15, figs. 3-6.

Diagnosis.-Specimens of Sigmocheilus with length of border (sagittal) between 2 and 3 times length of brim. Brim nearly flat. Fixed cheeks upsloping from dorsal furrow. External surface of border smooth or with few scattered low coarse granules. Pemainder of surface of cranidium, exclusive of furrows, covered with low fine granules.

Free cheek with moderately well defined lateral marginal furrow. External surface smooth except for low veination. 
Pygidium with poorly defined border moderately expanded posterolaterally, posterior margin broadly rounded or straight, with slight median indentation on some specimens. Edge smooth. Two or three low pleural ridges visible.

Discussion.--This species may require redefinition and subdivision when more is known of the associated cranidia, pygidia, and cheeks of early species of Sigmocheilus. The present collections contain slightly differing forms, but there are not enough specimens to establish certainly limits of variation of the differing features within a population. In this paper, s. grata includes forms with a smooth cranidial border, forms with a few low scattered granules on the border, and forms with slightly to moderately flared pygidial borders.

Occurrence: Moderately common, 50-80 ft above base of Inunderberg shale; units B and C. USGS colln. 952-CO, 2297Co-2299-Co.

Figured specimens: Plesiotypes-cranidium, pygidium, and free cheek, USNM 136895a-c, USGS colln. 2299-Co ; pygidium, USNM 136894, USGS colln. 952-CO.

\section{Sigmocheilus pogonipensis (Resser)}

Plate 10, figures $4-7$

Pterocephalina pogonipensis Resser, $1942 \mathrm{~b}$, p. 78 , pl. 15, figs. $1,2$.

Diagnosis.-Specimens of sigmocheilus with cranidium having brim strongly convex and border strongly concave. Length of border (sagittal) about 1.5 times length of brim. Front of glabella well defined because of arching of brim. Fixed cheeks upsloping from dorsal furrow. External surface of cranidium, exclusive of furrows and border, covered with low coarse granules.

Free cheek with poorly defined strongly concave border. Iateral marginal furrow hardly visible; posterior marginal furrow deep.

Pygidium with transverse subovate outline. Axial lobe about three-fourths length (sagittal) of pygidium. Border not clearly defined. Pleurae crossed by 4 or 5 prominent pleural ribs: lateral parts bear prominent terrace lines. Margin bears six pairs of short asymmetrical spines.

Iniscussion.-The strongly arched brim on the cranidium and short asymmetrical marginal spines on the pygidium are the most distinctive characteristics of this species. The holotype is from an unknown position within the Dunderberg shale in the White Pine district, Nevada.

ocurrence: Moderately common, 140-150 ft above base of Inunderberg shale: unit C. USGS colln. 954-CO, 2301-CO.

Figured specimens: Paratypes-cranidium, free cheek, and pygidium. USNM 136900a-c, USGS colln. 2301-CO; cranidium, USNM 136901, USGS colln. 954-CO.
Sigmocheilus serratus n. sp.

Plate 10, figures 1-3

Diagnosis.-Members of sigmocheilus with cranidium having length of border (sagittal) about 1.5 times length of brim. Brim gently to moderately convex, border moderately concave. Fixed cheeks upsloping. External surface of top of glabella with close-spaced fine granules.

Free cheek with poorly defined moderately ccrcave border. Surface of ocular platform with moderately prominent veination; border with moderately prominent terrace lines.

Pygidium transversely subovate in outline. Axial lobe about three-fourths length (sagittal) of pygidium. Border not defined. Pleurae crossed by 3 or 4 low pleural ridges. Posterior margin bears 5 or 6 pairs of broad rapidly tapered sharp marginal spines; the pair nearest axial line generally shorter than the remaining pairs. Pleurae with numerous terrace lines.

Discussion.-The relatively subdued convexity and concavity of the brim and border on the cranidium and the more prominent marginal spines on the pygidium distinguish this species from $\hat{S}$. pogonipensis. Isolated cranidia resemble those of $s$. grata but have a relatively broader brim.

Occurrence: Moderately common, 190-220 ft above base of Dunderberg shale; unit C. USGS colln. 789-CO, 864-CO, 878CO, 955-CO, 2302-CO.

Figured specimens: Holotype cranidium, USNM 136898a, USGS colln. 95n-CO. Paratypes: Pygidium, on same block as cranidium, USNM 136898b, USGS colln. 955-CO; free cheek, USNM 136899, USGS colln. 864-CO.

Sigmocheilus utahensis (Resser)

Plate 9, figures 24, 25, 28

Pterocephalina utahensis Resser, 1942b, p. 79, pl. 15, fig 7-11.

Diugnosis.-Specimens of Sigmorheilus with cranidium having border poorly defined by shallow marginal furrow. Length of border (sagittal) about 1.5 times that of brim. Brim gently convex and border gently concave. Glabella with moderately deep glabellar furrows. Fixed cheeks nearly horizontal. External surface of all but border of cranidium and furrows covered with close-spaced moderately coarse granules. Border with well-defined terrace lines.

Free cheek with poorly defined concave border. Pleural platform bears scattered coarse granules on external surface.

Pygidium with poorly defined border expanded posterolaterally and with moderately deep median indentation in margin. Two or three low pleural ridges generally visible. Surface of axial lobe and pleural platform seems to be roughened on larger specimens.

Hypostome and thoracic segments not known. 
Discussion.-This species is the oldest of the four species here assigned to Sigmocheilus. The poorly defined border and coarse-granular surface on the cephalon and the deep indentation in the posterior margin of the pygidium are its most distinctive features. The holotype is from the Orr formation, Fish Springs Range, Utah.

Occurrence: Rare, 30-50 ft above base of Dunderberg shale: unit B. USGS colln. 795-CO, 2296-CO.

Figured specimens: Plesiotypes-small cranidium, USNM 136897, USGS colln. 795-CO; free cheek and pygidium, USNMI 136896a, b, USGS colln. 2296-CO.

\section{PTYCHOPARIODEA UNASSIGNED}

Species and genera are not assigned to families in this paper if they are either well represented, but unlike any other trilobites in the collection; represented by small numbers of specimens, generally only cranidia; or are nearly featureless. If a stable family classification of Cambrian trilobites is to be developed, it must be built from groupings of two or more genera in which at least some of the species are well represented by cranidia, pygidia, and free cheeks. Monotypic families, families of superficially similar trilobites from rocks having no paleogeographic or stratigraphic continuity, or families for trilobites that are inadequately known do not contribute to stability.

\section{Genus ANECHOCEPHALUS n. gen.}

Diagnosis.-Pterocephaliidae? with cephalon having short frontal area. Brim nearly vertical; border slightly arched, subequal in length (sagittal) to brim, nearly horizontal. Fixed cheeks elevated; width about one-third basal glabellar width. Palpebral lobes raised above level on top of glabella; length (exsagittal) about two-thirds length of glabella; width about twothirds that of fixed cheeks; midlength situated posterior to glabellar midlength.

Pygidium subquadrate in outline with short posteriorly tapered axial lobe; border downsloping, poorly defined, broad, flat, with broad deep median notch in posterior margin.

Description.-Small pterocephaliid? trilobites (total length probably about $15 \mathrm{~mm}$ ). Cranidium with glabella well defined at sides and anterolateral corners, poorly defined on axial line; glabellar furrows shallow; occipital furrow deep, of nearly constant depth. Occipital ring gently arched along axial line, with low median node near anterior margin. Frontal area short; length (sagittal) about one-third length of glabella; subequally divided into well-defined brim and border. Brim nearly vertical, continuing forward curvature of glabella. Border gently convex, nearly horizontal, tapered slightly laterally. Fixed cheeks elevated; width about one-third basal glabellar width. Palpebral lobes large, situated slightly above level of top of glabella; length (exsagittal) about two-thirds length of glabella; width about two-thirds that of fixed cheek; midlength situated posterior to glabellar midlength; line connecting posterior ends passes just in front of occipital furrow. Posterior limbs slender, shape not known. Anterior course of facial sutures directed nearly straight forward from palpebral lobes to marginal furrow, then turned abruptly inward across border to cut anterior margin in front of glabella. Ventral course not known. Posterior course not known.

Free cheek, thoracic segments, and hypostome not known.

Pygidium subquadrate in outline. Axial lobe well defined, tapered posteriorly to inner edg 3 of border; bears 2 or 3 shallow ring furrows; length about onehalf and width about one-third that of pygidium. Pleural platforms nearly flat, horizontal, crossed by 2 or 3 shallow pleural furrows that extend slightly onto border. Border broad, flat, downsloping, differentiated from brim only by change in slope. Posterior margin with broad deep median notch not reaching to end of axial lobe.

External surface of border of cranidium covered with distinct terrace lines. Remainder of cranidium, except for glabellar and occipital furrows, bears low coarse imperfect reticulate ornament. External surface of pygidium smooth except for transverse row of three low coarse evenly spaced granules noar posterior margin on each side of median notch.

Discussion.-This genus is represented by 3 cranidia and 3 pygidia of a single species from 1 collection. It is not referable to any described genus, and has distinctive enough features to warrant description even though represented by a small sample. The association of cranidium and pygidium is not cartain, but it seems probable because these are the only unassigned parts of a pterocephaliid? trilobite in the collection from the type locality. Except for the frontal area, this genus has several characters of the Pterocephaliinae-prominent posteriorly placed palpebral lobes on raised fixed cheeks, poorly defined border, and curved pleural furrows extending onto the border of the pygidium. The subequally divided frontal area with a nearly vertical brim and a narrow border that is convex instead of concave upward is unlike that of any pterocephalinid.

\section{Anechocephalus trigranulatus n. sr.}

Plate 8, figures 21-23

Description.-In the absence of other species of Anechocephalus, the generic description is also a description of this species. The characteristics that will probably be most important in differentiating this species from any subsequently described are the reticu- 
late surface ornament of the cranidium and the distinctive rows of coarse granules near the posterior margin of the pygidium.

Occurrence: Rare, $70-80 \mathrm{ft}$ above base of Dunderberg shale: unit B. USGS colln. 952-CO.

Figured specimens: Holotype cranidium, USNM 136885. Paratypes, cranidium and pygidium, USNM 136886a, b. All from USGS colln. 952-CO.

\section{Genus BYNUMIELLA Resser}

Type species.-Bynumiella typicalis. Resser, 1942b, p. 57 , pl. 10, figs. $1,2$.

Diagnosis._-"Small trilobites with a tapering glabella without furrows. Dorsal and occipital furrows are well defined. The simple brim varies in width, but tends to extend forward in the middle causing the anterior outline of the cranidium to project." (Resser, 1942, p. 57.)

Discussion.-A single species from the lower part of the Dunderberg shale is tentatively assigned to this genus. Bynumiella is based on two species represented by only a few imperfectly preserved cranidia from beds of Franconia or Trempeleau age in the Canadian Rockies. Although the Dunderberg species seems to conform reasonably well to the generic diagnosis, the differences between this species and the Canadian species in both morphology and stratigraphic position indicate that another generic assignment may eventually result for the Dunderberg species when more is known about the relationships of the small smooth trilobites.

Bynumiella? acuminata n. sp.

Text figure 21 ; plate 10 , figures 9,10

Description.-Small trilobites (length of cranidium about $3 \mathrm{~mm}$ ) with cranidium subtriangular in outline, moderately arched transversely, gently arched longitudinally, sharply pointed at anterior margin. Glabella poorly defined by shallow dorsal furrow, straight sided, tapered forward, bluntly rounded anteriorly. Glabellar furrows not apparent. Occipital furrow deep adjacent to dorsal furrow, shallow on axial line. Occipital ring widest on axial line, with low median node near anterior edge. Frontal area short, with straight shallow marginal furrow separating downsloping brim and border; length slightly less than one-third length of glabella. Border flat, sharply pointed on axial line, tapered rapidly to point before reaching anterolateral corners of cranidium; length (sagittal) almost twice length of brim. Fixed cheeks moderately narrow, flat, downsloping; width slightly less than one-third basal glabellar width. Palpebral lobes hardly differentiated from cheek; situated slightly anterior to glabellar midlength; lateral margin gently curved outward, only slightly interrupting gentle inward curve of facial suture. Posterior limbs subtriangular; length (transverse) about three-fourths basal glabellar width. Posterior marginal furrow broad, shallow, straight. Anterior course of facial suture nearly straightforward from palpebral lobes, sharply curved inward before reaching marginsl furrow, and continuing in straight line across borter to cut anterior margin at distinct angle nearly at axial line. Posterior course divergent outward from palpebral lobe, nearly straight until across posterior marginal furrow, then curved backward to posterior margin.

External surface of occipital ring and posterior part of posterior limbs with many low coarse granules on some specimens, smooth or only faintly granular on others. External surface of remainder of cranidium smooth.

Free cheek with narrow poorly defined border. Ocular platform broad, smooth. Genal spine sl ort.

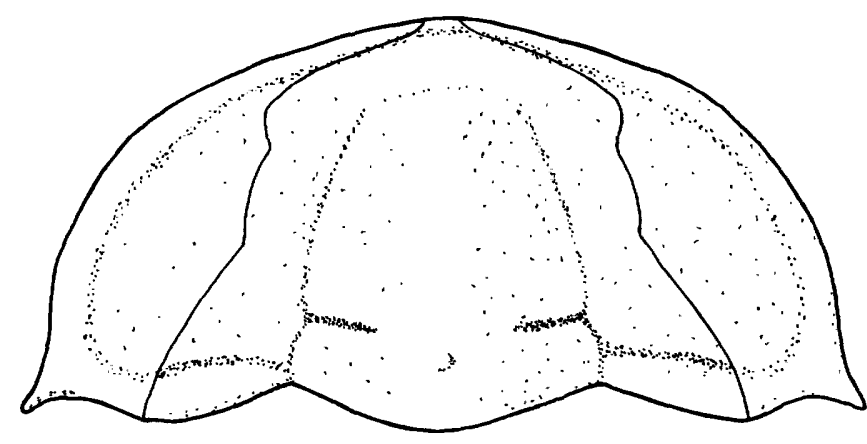

FIgURe 21.-Partial reconstruction of Bynumiella? acuminata $\mathrm{n}$. sp., about $\times 20$.

Discussion.-This species differs from B. typicalis Resser and B. briscoensis Resser by having a smooth rather than coarsely pitted external surface of the brim and cheeks and scattered coarse granules near the posterior margin of the cranidium, a somewhat more truncate anterior end to the glabella, a more sharply pointed anterior margin on the cranidium, and an occipital furrow that is deeper near the dorsal furrow and shallower on the axial line. No other known species in the Dunderberg fauna is likely to be confused with this one.

Occurrence: Noderately common, about $40 \mathrm{ft}$ above base of Dunderberg shale; unit B. USGS colln. 795-CO, 2296-CO.

Figured specimens: Holotype cranidium, USNM 136903, USGS colln. 2296-CO. Paratype free cheek, USNM 136904, UNGS colln. 2296-CO.

\section{Genus BYNUMINA Resser}

Bynuminu Resser, 1942, p. 58.

Type speriex.-Bynumina ruelutu Resser, 1942b, p. 58 , pl. 10, figs. 18-22.

Liagnosis.-Cranidium without distinct furrows on external surface. Anterior margin broadly rounded. No apparent border. Palpebral lobes small, situated 
anterior to midlength of cranidium. Posterior course of facial suture diverges at nearly right angle to axial line just behind palpebral lobe, then curres broadly to posterior margin.

Free cheek subtriangular in outline, with rounded genal angles.

Pygidium simple, without distinctive generic features.

Description.-Small nearly featureless trilobites (probably not much more than $10 \mathrm{~mm}$ in total length) with cranidium subtrapezoidal in outline, moderately arched transversely and longitudinally, without distinct external furrows. Exfoliated specimens have well-defined anteriorly tapered glabella, slightly rounded at front. Last two pairs of glabellar furrows, when present, strongly curved posteriorly. Occipital furrow deep, straight. Occipital ring narrow, tapered laterally. Frontal area length slightly greater than one-third that of remainder of cranidium; shallow marginal furrow when present, separates brim and border of nearly equal length. Posterior limbs broad (exsagittal), shorter (transverse) than basal glabellar width, bluntly rounded or pointed at tips; marginal furrow only apparent near dorsal furrow. Anterior course of facial suture straight forward or slightly convergent from palpebral lobes to anterolateral corners of cranidium, then curved gently inward to cut anterior margin imperceptibly about in front of anterolateral corners of glabella. Posterior course nearly straight laterally directly behind palpebral lobe, then curved broadly ot posterior margin.

Free cheek subtriangular in outline, without welldefined border. Eye small. Genal spines absent, genal angles strongly rounded.

Pygidium subsemicircular in outline; axial lobe not distinctly differentiated on external surface; border not apparent. On exfoliated specimens, axial lobe tapers backward nearly to posterior margin, not well defined by dorsal furrow, bears up to five shallow ring furrows. First two axial segments more distinctly dereloped than more posterior segments in some species.

External surfaces of all parts smooth.

Discussion.-Neither Resser (1942) when he proposed this genus for $B$. cuelata Resser and $B$. missouriensis Resser from the Daris formation of Missouri, nor Wilson (1951) when he added $B$. terrenda. Wilson from the Ore Hill limestone member of the Gatesburg formation in Pennsylrania and compared it with the type species seems to have recognized that the types of the Missouri species are exfoliated cranidia. Reexamination of the type lots of $B$. caelatu and $B$. missouriensix has turned up one cranidium in each lot that retains its exoskeleton. The appearance of these cra- nidia is much like that of $B$. terrenda. (Wilson, 1951, pl. 89, fig. 10) and quite unlike the exfoliated specimens.

The gently rounded anterior margin, absence of a distinct cranidial border, and strongly divergent posterior course of the facial sutures on the cranidium distinguish species of this genus from other nearly featureless trilobites. A single distinct species, B. globosa (Walcott), represents this genus in the Dunderberg fauna.

The descriptions of the free cheek and pygidium are based on material from the Davis formation in Missouri.

Bynumina globosa (Walcott)

Plate 10 , figure 8

Agraulos? globosus Walcott, 1884, p. 61, pl. 9, fig. 23. Kingstonia globosa (Walcott). Resser, 1936, p. 24.

Diagnosis.-Specimens of Bynumina with cranidium having glabella nearly parallel sided, subquadrate in outline; anterior part somewhat elevated above adjacent cheeks. Thoracic segments, free chaeks, and pygidium not known.

Discussion.-The distinct, although not clearly defined subquadrate glabella, is the prinnipal feature distinguishing this species from others in Bynumina. Its relations to the older genus $L$ ingstonia cannot be determined until more is known of these nearly featureless trilobites.

Ocrurrence: Moderately common, upper Dunderberg shale; unit D. USNM loc. 61.

Figured specimen: Cranidium, USNM 136?2, USNM loc. 61.

\section{Genus CHEILOCEPHALUS Berkey}

Cheilocephalus Berkev, 1898, p. 290 ; Palmer, 1974, p. 757.

Pseudolisania Kobayashi, 1935, p. 162; Shimar and Shrock, 1944 , p. 621.

The fragmentary material from the Dunderberg shale does not add any new information to the description of this genus already presented (Palmer, 1954).

\section{Cheilocephalus spp.}

Plate 10 , figures 13,14

Discussion.-Two cranidia and a pygidium from three different collections represent this rare but distinctive genus in the Dunderberg shale. None of the specimens are completely preserved. The two cranidia have a distinctive coarse granular externsl surface and are perhaps referable to Cheilocephalus buttsi Resser (Resser, 1942, p. 36, pl. 11, fig. 6; Wilson, 1951, p. 631, pl. 91, fig. 13). This species is known f:om only two cranidia in the Ore Hill limestone member of the Gatesburg formation in central Pennsylvania.

The pygidium is exfoliated so that, although it has a shape characteristic of pygidia of several species of 
Cheilocephalus, its external surface and thus its affinities are not known.

Reference of the Dunderberg material to new or described species must await more complete information about the morphology of associated cranidia and pygidia.

Occurrence: Rare, Dunderberg shale; units B, C. USGS colln. 864-CO, 872-CO, 2299-CO.

Figured sperimens: Cranidium, USNM 136907, USGS colln. 864-CO ; pygidium, USNM 136908, USGS colln. 2299-CO.

\section{Genus DOKIMOCEPHALUS Walcott}

Dokimocephalus Walcott, 1924 , p. 55; 1925, p. 83; Shimer and Shrock, 1944, p. 623; Frederickson, 1948, p. 800; Wilson, 1949 , p. 36.

Type species.-Ptychoparia? pernasutus Walcott, 1884, p. 49 , pl. 10 , figs. $8,8 \mathrm{a}-\mathrm{b}$.

Discussion.-On the basis of relatively abundant material in Oklahoma and Texas, Frederickson (1948) and Wilson (1949) gave detailed descriptions of this genus. Only 2 imperfect cranidia and 1 free cheek represent the genus in the Dunderberg faunas.

Dokimocephalus resembles Iddingsia in having a prominent glabella with deep posteriorly directed glabellar furrows. It differs from Iddingsia primarily in having the border greatly extended anteriorly.

Dokimocephalus pernasutus (Walcott)

Plate 11, figures 18,20

Ptychoparia? pernasutus Walcott, 1884, p. 49, pl. 10, figs. 8, 8a-b. Dokimocephalus pernasutus (Walcott). Walcott, 1924, p. 55, pl. 11, fig. 1 ; 1925 , p. 84 , pl. 16, figs. 29-31.

'Dokimocephalus gregori Walcott, 1925, p. 8t, pl. 16, figs. 32-33; Shimer and Shrock, 1944, pl. 264, figs. 38, 39.

Diagnosis.-Members of Dokimocephalus with border forming a pointed snout with concave sides and with tip curved down at end.

Discussion.-This species is represented by 2 fragmentary cranidia and 1 free cheek that are inadequate for the preparation of a description of the species characteristics. Neither cranidium has its fixed cheeks, lateral margins, or external surface preserved. The free cheek is also exfoliated. Only one cranidium, the holotype, retains the distinctive pointed snout.

$D$. gregori Walcott, from Missouri, may be conspecific with $D$. permusutus. It has a nearly identical shape to the border and differs only slightly in observable proportions of other cranidial features. Tntil better material of $D$. pernasute is obtained, such a synonymy cannot be definitely established.

orcurrence: Rare, upper beds of Dunderberg shale; unit

D. USNMI loc. 61.

Figured specimens: Holotype cranidium, USNM 24608a. Paratype free cheek, USNM 24608b.

\section{Genus IDDIrGSIA Walcott}

Iddingsia Walcott, 1924, p. 58; 1925, p. 97 ; Shimer and Shrock, 1944, p. 627. Bell, and others, 1952, p. 184.

Type species.-Ptychoparia similis Walcott, 1884, p. 52, pl. 10, fig. 10.

Diagnosis.-Cranidium with prominent g]abella bearing 1 or 2 pairs of deep glabellar furrows. Frontal area expanded anteriorly, length between $1 / 2$ and $2 / 3$ that of glabella; subequally divided into brirn and border. Fixed cheeks generally upsloping, narrow; eye ridges prominent; palpebral lobes well defined, strongly bowed. Posterior limbs narrow (exsagittal) tajered to sharp point.

Free cheek with deep lateral and posterior marginal furrows and long posterolaterally directed cylirdrical genal spine.

Pygidium transverse subtriangular in outline. Axial lobe prominent, slightly tapered, reaching to inner edge of poorly defined narrow border that is nearly absent on axial line.

Description.-Medium to large trilobites (up to about $90 \mathrm{~mm}$ in length) with cranidium bearing prominent glabella well defined by dorsal furrow that is deep at sides, slightly bowed outward, and deep or shallow across front of glabella. One or two pairs of short deep posteriorly directed glabellar furrows always present. Occipital furrow broad, deep, deepest adjacent to dorsal furrow. Occipital ring generally with median node, rarely with median spine. Frontal area long (sagittal); length about two-thirds that of glabella; subequally divided into downsloping to depressed brim and gently downsloping to horizontal, concave, flat, or slightly arched border by shallow marginal furrow or sharp change in slope. Morginal furrow generally comes to blunt point on axial line. Fixed cheeks upsloping to elevated, bearing distinct posterolaterally directed eye ridges; width between $1 / 3$ and $1 / 2$ that of glabella. Palpebral lobes strongly bowed, well defined by deep palpebral furrow; length between $1 / 3$ and $1 / 2$ that of glabella; width $1 / 3$ to $1 / 4$ that of fixed cheeks. Posterior limbs narrow (exsagittal), dominated by broad deep posterior merginal furrow; tapered to sharp point; length (transverse) slightly less than basal glabellar width.

Anterior course of facial suture divergent from palpebral lobe to inner edge of border, then angled inward across border to cut anterior margin ir front of fixed cheek. Posterior course strongly divergentsinuous.

Free cheek subtriangular in outline with brond flat or slightly arched border well defined by deep lateral marginal furrow. Lateral marginal furrow may or may not be connected to deep posterior marginal furrow. Genal spine long, large, cylindrical, straight, or 
slightly curved, directed posterolaterally at slight angle to margin of cheek.

Pygidium transversely subtriangular in outline; axial lobe prominent, gently tapered posteriorly, bluntly rounded, extended to inner edge of border. Three or four distinct ring furrows present. Pleural platforms flat or slightly arched, bearing 1 or 2 shallow pleural furrows. Border narrow, poorly defined, tapered towards axial line, nearly absent behind axial lobs.

Thoracic segments and hypostome not known.

Discussion.-Iddingsia was proposed by Walcott (1924, 1925) to include Ptychoparia simitis Walcott and Ptychoparia similis robusta. Walcott known only from cranidia in collections from the Eureka district, Nevada. A brief statement of the generic characteristics was given at that time. No subsequent description of the genus has been presented until now. Meanwhile, Kobayashi (1938) added $I$. concuva and Resser (1942a) added nine new species, $I$. alpersensis, I. anatina, I. bicinctu. I. crassimarginatu, I. missouriensis, I. nevadensis, I. simplicitas. I. utahensis, and I.? quinnensis. Wilson (1949) proposed a new genus, Plataspella, typified by $I$. anatina, to include five of Resser's species that differed from $I$. simitis (Walcott) by possessing an occipital spine, shallow glabellar furrows, and "a much more flattened and laterally expanded border and brim which lack the convexity of those Iddingsia." Later, Wilson (1951) reported intergradation of features formerly thought to be distinctive of Iddingsia or Plataspella but continued to recognize Plataspella as a distinct genus. Bell, Feniak, and Kurtz (1952, p. 184) concluded that "the characters used by Wilson to separate Plataspella from Iddingsia are not generically significant ***" and made Plataspella a subjective junior synonym of Iddingsia. Lochman (1953) concurred with this conclusion. Since then, one additional species, $I$. occidentalis Deland and Shaw (1956), has been added to the genus.

To prepare a description of Iddingsia and determine its characteristics, type material for all the species assigned to Iddingsiu except $I$. occidentalis Deland and Shaw has been reexamined. In this complex of trilobites, the texture of the external surface of the cranidium, as in the Elviniidae, is the most reliable primary feature for differentiation of species. Within any one collection, all cranidia have the same external surface texture. None of the collections are large enough to provide adequate statistical basis for many of the slight differences in shape cited as distinctive for various species of the genus. Although some of the characters given by Wilson for Plutuspella do not seem important as generic characters, there is a group of trilobites, including $P$. anatinu (Resser), that lack conspicuous glabella furrows and differ among them- selves in surface texture. They also generally have an occipital spine and nearly horizontal fixed cheeks. In the light of what has been learned during this study about the taxonomic importance of shape and surface texture in the better represented trilobite groups in the Dunderberg shale, the trilobites resembling $P$. anatina (Resser) and bearing the characters cited above are here considered to represent a separate genus from those resembling $I$. simitis. Only Iddingsia is represented in the Dunderberg faunas.

As now constituted, Iddingsia includes four described species with the following primary distinguishing external textural characters on their cranidia: I. similis (Walcott), top of glabella and occipital ring covered with close-spaced moderately coarse granules, fixed cheeks and frontal area smooth; I. robusta (Walcott) (syn. I. nevadensis Resser), entire cranidium covered with close-spaced generally small granules of several sizes; $I$. utahensis Resser, surface of entire cranidium smooth though top of glabella frintly roughened; I. missouriensis Resser (syn. I. crassimarginata Resser), glabella and occipital ring covered with low coarse granules, frontal area covered with close-spaced fine pits, fixed cheeks with both fine pits and low coarse granules.

Precise stratigraphic placement of I. utahensis and I. missouriensis within the Elvinia fauna is not yet known. I. simitis occurs with other trilobites known only in association with Irvingella (Irvingella) major Ulrich and Resser in the basal beds of the Windfall formation which overlies the Dunderberg shale. $I d-$ dingsie robusta is associated with trilobites known only in association with Kindbladin and Iringolla (Parairvingella) in the upper beds of the Dunderberg shale.

The specimen identified by Bell, Fenial-, and Kurtz as $I$. simitis (1952, pl. 30, fig. $4 \mathrm{~b}$ ) may represent a fifth species of Iddingsia characterized by an occipital spine. The other specimen identified as $I$. similis by Bell, Feniak, and Kurtz (1952, pl. 31, fg. 2) represents a species of Plataspella. Species relationships of the remaining specimens of Iddingsia illustrated by Bell, Feniak, and Kurtz (1952), I. nevadensis illustrated by Wilson (1949), and $I$. occidentatis Deland and Shaw (1956) cannot be made withort knowledge of their external surface textures. Iddingsia concava. Kobayashi is represented by a single specifically indeterminate cranidium. I.? quinnensis Resser belongs to sigmocheilus n. gen. (p.90).

\section{Iddingsia robusta (Walcott)}

Plate 11, figures 13-16

Ptychoparia similia robustus Walcott, 1884, p. 53, pl. 1, figs. 9, 9 a.

Iddingsia robusta (Walcott). Walcott, 1924, p. 97, pl. 16, figs. 10-11.

Iddingsia nevadensis Resser, $1942 \mathrm{~b}$, p. 85, pl. 16 figs. 15-17. 
Diagnosis.-Members of Iddingsia with dorsal furrow generally shallow across front of glabella. Length of frontal area slightly greater than one-half length of glabella. Brim and border separated by abrupt change in slope. Border nearly flat, slightly downsloping. Fixed cheeks upsloping; width about onethird basal glabellar width. Occipital ring with low median node. External surface covered with closespaced generally small granules of several sizes. Some of the granules along brim arranged in rows paralleling veination.

Discussion.-This species is represented only by cranidia. It differs from $I$. similis (Walcott) from the overlying Windfall formation by having a granular rather than smooth surface on the brim and border. Exfoliated specimens of the two species cannot be identified or differentiated with certainty.

Iddingsia nevadensis Resser is represented by one nearly completely exfoliated specimen that retains a small piece of the granular external surface of its border, and is not significantly different in any respect from 1 . robusta.

Occurrence: The holotype is associated with Bynumina globosa (Walcott), a species known only from the upper beds (unit $\mathrm{D}$ ) of the Dunderberg shale.

Figured specimens: Holotype cranidium USNM 24609, USNM loc. 61; plesiotype cranidium, USNM 136924, USNM loc. 62 ; I. nevadensis holotype, USNM 108796, USNM loc. 61.

\section{Genus KINDBLADIA Frederckson, 1948}

Kindbladia Frederickson, 194\$, 1. s/2.

Type species.-Berkeiu wichitrensis Resser, 1942b, p. 93, pl. 15, figs. 31,33 .

Discussion.-A good description of this genus was given by Frederickson (1948) on the basis of abundant material from the Honey Creek formation in Oklahoma. The genus is represented in the Dunderberg shale by a single species, $K$. affinis (Walcott), known only from cranidia.

Resser (1942a, p. $\tau$ ) included $K$. affinis in Berlieia without stating reasons why he had changed his earlier assignment of the species (Resser, 1937, p. 1t) to Iddingsia. This species and most of the other species assigned to Berkieia by Resser (1942b) differ from the type species of Berkeia, B. typica Resser, by having more strongly arched and upsloping fixed cheeks and by having three shallow depressions in the marginal furrow. Frederickson (1948) included species with these characters in his new genus Kindbludia. This genus can be distinguished from all others in the Dunderberg fauna by its prominent anteriorly tapered glabella, strongly rounded in front and bearing two deep pairs of glabellar furrows; deep dorsal furrow; narrow upsloping convex fixed cheeks; and short subequally divided frontal area with three shallow depressions in the marginal furrow.

\section{Kindbladia affinis (Walcott)}

Plate 11, figures $17,19,20$

Ptychoparia (Euloma?) affinis Walcott, 1884, p. 54, pl. 10, fig. 12. Iddingsia affinis (Walcott). Resser, 1937, p. 14.

Berkeia affinis (Walcott). Resser, $1942 \mathrm{a}$, p. 7.

Berkeia comes Resser, 1942b, p. 90, pl. 15, figs. 18-21.

Berkeia nevadensis Resser, 1942b, p. 91, pl. 15, figs. 26, 27.

Diagnosis.-Members of Kindbladia with occipital ring bearing median node rather than median spine.

Description.-Small to medium-sized trilobites (probably about $20 \mathrm{~mm}$ in total length) with cranidium having prominent anteriorly tapered glabella, strongly rounded in front, with slight keel on axial line. Two pairs of short deep glabellar furrows generally present; posterior pair strongly curved backward. Iorsal furrow deep around entire glabella. Occipital ring well defined by deep occipital furrow; bears prominent median node. Frontal area short; length about two-fifths that of glabella; subequally divided by deep marginal furrow into brim and border both moderately to strongly convex and slightly downsloping on axial line. Marginal furrow broadly curved in dorsal view; depressions in marginal furrow shallow, most apparent on exfoliated specimens. Fixed cheeks moderately to strongly arched, upsloping from dorsal furrow, narrow; width slightly less than onefourth basal glabellar width. Palpebral lobes well defined by palpebral furrow; width slightly mors than one-half that of cheek; length about two-fifths that of glabella. Posterior limbs tapered to a point laterally, downsloping; length (transverse) slightly less than basal glabellar width. Posterior marginal furrow deep, nearly straight. Anterior course of facial suture slightly divergent forward from palpebral lobes to marginal furrow, then curved strongly across border and apparently submarginal to axial line. Posterior course divergent, sinuous. External surface covered with fine close-spaced granules.

Thoracic segments, free cheeks, pygidium, and hypostome not known.

Discussion.-Nearly all the cranidia of Kindbladia. affinis and those in the type lots of the other species of hindbladia are exfoliated. This tends to emphasize the depth of all the furrows and limits comparison of the described species. One of the rare spe-imens of $K$. affinis retaining its external surface is illustrated (pl. 11, fig. 17). No consistent distinction can be made between the specimens, mostly exfoliated, in the type lots of $K$. affinis, Berkia nevadensis Resser, and $B$. comes Resser. They are here considered conspecific, and represent a species differing from $K$. wichitaensis (Resser) and $K$. retust (Resser) by lacking an occipital spine.

occurrence: Moderately rare, $230 \mathrm{ft}$ or more above base of Dunderberg shale; unit D. USGS colln. 2303-CO. 
Figured specimens: Holotype cranidium, USNM 24642, USNM loc. 65. Plesiotype, USNM 136925, USNM loc. 61. Holotype of $K$. nevadensis (Resser), USNM 108i88a, USNM loc. 61 .

\section{Genus MINUPELTIS n. gen.}

Type species.-Minupeltis conservator n. sp.

Diagnosis.-.Small trilobites with subquadrate cranidium having glabella well defined only at sides; not defined across front. No distinct glabellar furrows. Occipital furrow straight, deepest on axial line. Frontal area with moderately well defined strongly arched (sagittal) border; inner part nearly horizontal, outer part nearly vertical. Fixed cheeks gently arched, downsloping; palpebral lobes small about opposite glabellar midlength. Posterior limbs short; length about two-thirds basal glabellar width. Anterior course of facial sutures straight forward from palpebral lobes to marginal furrow, curved inward across border to cut anterior margin in front of glabella.

Description.-Small trilobites (total length probably less than $10 \mathrm{~mm}$ ). Cranidium subquadrate in outline, gently arched transversely and longitudinally. Glabella prominent, well defined at sides by shallow dorsal furrow, not defined across front. Sides slightly bowed. Glabellar furrows not apparent. Occipital furrow straight, narrow, deepest on axial line. Frontal area downsloping; length (sagittal) slightly less than one-half length of glabella, subequally divided into brim and border. Border well defined by broad shallow marginal furrow; strongly arched in profile, inner part nearly horizontal, outer part nearly vertical. Brim not differentiated from front of glabella. Fixed cheeks gently arched, downsloping; width about one-third basal glabellar width. Palpebral lobes hardly differentiated from cheek, situated about opposite glabellar midlength; length about one-third that of glabella. Posterior limbs short, bluntly pointed; length (transverse) about two-thirds basal glabellar width. Posterior median furrow straight, shallow. Anterior course of facial suture nearly straightforward from palpebral lobes to marginal furrow, then curved abruptly inward across border to cut anterior margin between axial line and point opposite anterolateral corner of glabella. Posterior course of facial suture divergent from palpebral lobe, slightly bowed outward.

Free cheek, hypostome, thoracic segments, and pygidium not known.

External surface of all parts smooth, shiny on wellpreserved specimens.

Discussion.-This distinctive trilobite is moderately common in the lowest collection from the Dunderberg shale. It does not resemble closely any described Upper Cambrian trilobite from western North America, or any other trilobite from the Aphelaspis, Dunder- bergia, or Elvinia faunas. The overall form of the cranidium, except for the anterior course of the facial sutures, is similar to that of simple Lower Cambrian ptychoparioids like Crassifimbra (Palmer, 1958); hence the species name, conservator. The subequally divided frontal area, slightly bowed sides to the glabella, and small poorly defined centrally located palpebral lobes indicate possible affinities to solenopleurid trilobites, such as species of Parasolenopleura (Westergard, 1953). Minupeltis differs from similar Lower Cambrian trilobites primarily by having the facial sutures cutting the anterior margin nearer the axial line; it differs from similar solenopleurid forms by having the front of the glabella not defined and by laving the border strongly arched in longitudinal profile.

\section{Minupeltis conservator n. sp. \\ Plate 10, figures 11, 12}

Description.-This is the only species presently known in Mimupeltis, and the description of the genus also gives the characters of the species.

Discussion.-One cranidium in the type lot (pl. 10, fig. 12) is an unusual pathologic specimen on which the right side is not so well developed as the left. This is particularly noticeable on the pesterior limb and at the right anterolateral corner of the cranidium.

Occurrence: Moderately common, lower $2 \mathrm{C}$ ft of Dunderberg shale; unit A. USGS colln. 2294-CO.

Figured specimens: Holotype cranidium, USNM 136905, USGS colln. 2294-CO. Paratype pathologic cranidium, USNM 136906, USGS colln. 2294-CO.

\section{Genus MOROSA n. gen.}

Text figure 22

\section{Type species.-Morosa longispina n. sp.}

Diagnosis.-Housidae? with axial length of frontal area slightly less than one-third glabollar length. Frontal area subequally divided into well-defined brim and border. Border tapered laterally to a point just before reaching anterolateral corner of cranidium. Anterior margin in front view nearly horizontal; course of marginal furrow in front view strongly bowed upward. Glabella well defined. Glabellar furrows hardly visible. Fixed cheeks narrow, gently arched upward, nearly horizontal; width slightly less than one-fourth basal glabellar width. Palpebral lobes prominent, situated anterior to midlongth of glabella. Occipital ring with prominent median node.

Free cheek with narrow border. Mar rinal furrow distinct at anterior margin, disappears posteriorly. Genal spine broad at base, flat, tapered to sharp point. Inner and outer margins straight.

Pygidium with prominent axial lobe extending to inner edge of moderately wide, slightly concave, poorly 
defined border that maintains nearly constant width along entire pygidial margin.

External surface of exoskeleton except areas of muscle attachment covered with distinct pits. Surfaces of pleural lobes and axial lobe of pygidium also bear low fine granules. Surface of mold smooth or pitted.

Marginal parts of cephalon and pygidium with prominent terrace lines.

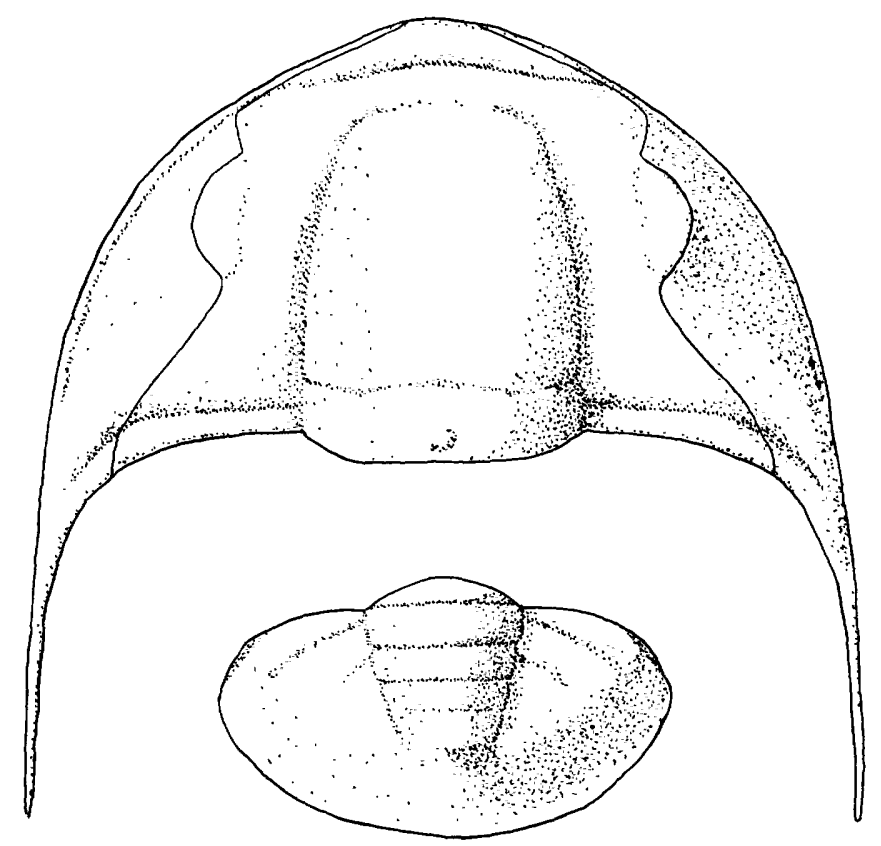

FIGURE 22.-Partial reconstruction of Morosa longispina $\mathrm{n}$, sp., about $\times 15$.

Description.-Generally small trilobites (length probably less than $20 \mathrm{~mm}$ ) with cranidium having well-defined straight-sided anteriorly tapered glabella, truncate anteriorly. Dorsal furrow deepest at sides and anterolateral corners of glabella, somewhat shallower across front. Occipital furrow straight, deepest at side of glabella, shallow on axial line. Occipital ring with prominent median node. Glabellar furrows generally not apparent. Frontal area short, depressed; length (sagittal) slightly less than one-third glabellar length. Border well defined, downsloping, tapered laterally to a point just before reaching the anterolateral corners of the cranidium. Course of marginal furrow when riewed from the front, strongly bowed upward. Length (sagittal) of border slightly greater than length of brim. Fixed cheeks narrow, gently arched upward, nearly horizontal. Width slightly less than one-fourth basal glabellar wilth. Short poorly defined eye lines present. Palpebral lobes well defined by nearly straight shallow palpebral furrow; width slightly more than one-half width of fixed cheek; length slightly less than one-half length of glabella. Posterior limbs slightly backswept; slightly shorter (transverse) than basal glabellar width. Posterior marginal furrow deep. Facial sutures divergent anteriorly from palpebral lobe almost to marginal furrow, then curved sharply inward across marginal furrow and border to cut anterior margin near, but not at, axial line. Submarginal course not known.

Thoracic segments and hypostome unknown.

Free cheek with ocular platform well defined along anterolateral and posterior margins, merges posterolaterally with genal spine. Border narrow; width at anterior margin between $1 / 3$ and $1 / 4$ width of ocular platform. Lateral marginal furrow distinct but shallow at anterior margin, disappears posteriorly. Posterior marginal furrow deep at junction with pcsterior limb, disappears laterally. Genal spine broad at base, flat, tapered to a sharp point. Outer and inner margins straight. Length about two-thirds length of ocular platform.

Pygidium with prominent posteriorly tapered axial lobe bearing three conspicuous ring furrows and $e^{-}$tending to inner edge of poorly defined border. Pleural platform triangular, crossed by 1 or 2 pleural furrows that do not extend onto border. Border slightly concave, maintains nearly constant width along pygidial margin. Posterior margin smooth.

Surfaces of all known parts of exoskeleton except muscle-scar areas on cranidium are covered with numerous distinct pits of variable size. Prominent terrace lines on margins of cephalon and pygidium. Pleural platform and axial lobe of pygidium with low poorly defined granules.

Discussion.-This distinctive genus is represented by only a single rather common species that has no apparent ancestors or descendants in the Dunderberg shale fauna. It may belong to the Housiidae because of the anteriorly placed palpebral lobes on the cranidium and the even width of the pygidial border. However, the character of the frontal area and the distinct palpebral furrows are not typical of the family, and the genus is not here assigned to any family or subfamily.

\section{Morosa longispina n. sp.}

Plate 10, figures 15-17

Diannosin-As this is presently the only described species of Morosa, the diagnosis is the same as that for the genus.

Iniscussion.-The range of this abundant species is sufficiently restricted to mark a distinctive faumal subzone within the Dunderberg shale. A second species of this genus is known, but not yet described, from the basal beds of the Nopah formation in California. It differs from $\boldsymbol{M}$. longispina principally in having 
much shorter genal spines and a relatively broader free cheek.

Occurrence: Abundant, $40-100 \mathrm{ft}$ above base of Dunderberg shale: unit B. USGS colln. 795-CO, 873-CO, 2296-CO, 2298-CO-2300-CO.

Figured specimens: Holotype cranidium, USNM 136909, USGS colln. 2299-CO. Paratypes, pygidium and free cheek USNM 136910a, b, USGS colln. 2299-CO.

\section{Genus OLIGOMETOPUS Resser}

Oligometopus Resser, 1936, p. 28.

Type species.-Ptychoparia (Solenopleura?) breviceps Walcott, 1884, p. 49, pl. 10, fig. 9.

Diagnosis.-Small trilobites with cranidium having well-defined anteriorly tapered glabella reaching to marginal furrow. Border straight, thickened, nearly vertical. Fixed cheeks moderately arched, slightly downsloping; width about one-half basal glabellar width. Palpebral lobes small, narrow, situated below level of cheek about on line through glabellar midlength. Posterior limbs short; length (transverse) less than basal glabellar width. External surface of cranidium covered with low coarse granules.

Free cheek, hypostome, thorax, and pygidium not known.

Description. - Small trilobites (length of cranidium about $4 \mathrm{~mm}$ ) with cranidium subquadrate in outline. anterior margin nearly straight. Glabella prominent, well defined by broad dorsal furrow, straight sided, tapered forward, bluntly rounded anteriorly, extended to marginal furrow. Three pairs of broad shallow glabellar furrows visible. Occipital furrow deep, deepest adjacent to dorsal furrow. Occipital ring broken on known specimens, shape not known. Frontal area made up entirely of narrow border that is thickened and nearly vertical along entire anterior margin. Fixed cheeks broad, moderately arched upward, slightly downsloping; width about one-half hasal glabellar width. Low ocular ridges extend obliquely outward and backward from junction of glabella with marginal furrow. Palpebral lobes well defined, small, situated below general level of cheek about on line through glabellar midlength; length about one-third that of glabella; width about one-fifth that of cheek. Posterior limbs short, bluntly terminated: length (transverse) less than basal glabellar width. Posterior marginal furrow broad, deep, straight. External surface of all parts except border and furrows covered with low coarse granules. Border bears conspicuous terrace lines.

Anterior course of facial suture slightly convergent forward from palpebral lobe to marginal furrow, then turned abruptly inward and nearly straight across border to cut anterior margin near anterolateral corners of cranidium. Posterior course directed laterally in a broad curve to posterior margin.
No other parts of exoskeleton known.

Discussion.-This rare genus seems to have affinities to asiatic genera, such as Chuangia and Pagodia, which also have broad fixed cheeks and a glabella that reaches to, or nearly to, the marginal furrow. Otigometopus differs from the asiatic genera either in the shape of the glabella or of the frontal area. No American or other foreign genera can be easily confused with Oligometopus. The placement of this genus in a family and adequate comparison with known genera must await knowledge of other parts of the exoskeleton.

\section{oligometopus breviceps (Walcott)}

Plate 10, figures 19,20

Ptychoparia (Solenopleura?) breviceps Walcott, 1884, p. 49, pl. 10 , fig. 9 .

(Iligometopus breviceps (Walcott). Resser, 198\%, p. 29.

Stenclymus breviceps (Walcott). Raymond, 1937, p. 1101.

Discussion.-Raymond's reference of this species to Ntenelymus seems to have been based on inadequate knowledge of the holotype. The shapes of the fixed cheeks, glabella, and frontal area are urlike those in Stenelymus. Recently, Lochman (1953, p. 888) considered stenelymus a synonym of Genevievella, a genus that is entirely unlike oligometopus in its critical diagnostic features.

Besides the holotype, only one other cranidium of O)igometopus is known. This specimen shows that the species had a granular external cranidial surface rather than a smooth surface as stated by Walcott. The holotype, which has most of its external surface damaged, shows the granules on the posterior limbs.

Occurrence: Rare, $140 \mathrm{ft}$ or more above base of Dunderberg shale; units $C$, D. USGS colln. 954-CO.

Figured specimens: Holotype, USNM 24577, USNM loc. 62. Plesiotype cranidium, USNM 136913, USGF colln. 954-CO.

\section{Genus PINCTUS Wilson}

Type species.-Pinctus latus Wilson, 1951, p. 646, pl. 93, figs. 1-4, 15.

Description.-This genus was described by Wilson (1951, p. 646).

Cranidium small and bluntly triangular in shape, moderately convex with well-developed furrows. Glabella very long, prominent, convex, and quadrate with three pairs of well-impressed oblique furrows; occipital ring posteriorly extended at axis. Brim reduced and depressed; border prominent, widely arcuate, and considerably tapered; brim: border ratio about 1 or less. Fixed cheeks downsloping, morlerately wide (ratio 2 or less) ; palpebral lobes small and thin, slightly anterior: posterior limbs broad and extended.

Facial suture intramarginal almost to axis, $k$ eginning to diverge already just behind anterolateral corner, indenting but slightly at each end of palpebral lobe, and sweeping outward behind it enough to give cranidium a wide base. 
Pinctus? spp.

Plate 10, figures 18,21

Three small cranidia represent two species of a trilobite possibly related to Pincutus latus Wilson. The cranidia are characterized by a prominent glabella; small anteriorly placed palpebral lobes; broad arched horizontal or slightly downsloping fixed cheeks; and a well-defined border about equal in length (sagittal) to the brim. Two of the cranidia, from USGS collection 952-CO, have the palpebral lobes distinctly defined, distinct glabellar furrows, and a border that is of nearly constant width across much of the front of the cranidium. The third cranidium, from USGS collection 953-CO, has undefined palpebral lobes, shallow, hardly apparent glabellar furrows, and a border that taper's rapidly laterally from the axial line, much like that of Morosa. longispina n. sp.

Both species differ from Pinctus latur in having smooth rather than fine-granular external surfaces and in having broader and shorter glabellas. Certain generic and specific identification of these trilobites must await more knowledge of the small trilobites in the Dunderberg and related faunas.

Occurrence: Rare, $60-120 \mathrm{ft}$ above base of Dunderberg shale; units, B, C. USGS colln. 952-CO, 953-CO.

Figured specimens: Cranidium, USNM 136911, USGS colln. 952-CO : cranidium, USNM 136912, USGS colln. 953-CO.

\section{Genus PSEUdOSARATOGIA Wilson 1951}

\section{Pseudosaratogia Wilson, 1951, p. 647.}

Type species.-Pseudosaratogiu magna. Wilson, 1951, p. 648 , pl. 94, figs. 9-16.

Diagnosis.-Elviniidae? with flaring frontal area on cranidium; axial length of border about one-half or less axial length of brim.

Discussion.-A complete description of this genus was given by Wilson (1951). Specimens of Pseudosaratogia are rare in the Dunderberg shale and do not provide any new information concerning the morphology of the genus. The two species here described have a rounded glabellar front and nearly horizontal cheeks, similar to Preudosaratogia 7ata Wilson from the Ore Hill limestone member of the Gatesburg formation in central Pennsylvania. This species was considered a somewhat aberrant form by Wilson (1951). The palpebral lobes are also somewhat smaller than those of the Pennsylvania species. Nevertheless, the overall characteristics of the cranidia are more suggestive of Pseudosurutogia than other genus.

Pseudosaratogia leptogranulata n. sp.

Plate 11, figure 10

Diagnosis.-Specimens of Preudosaratogia with cranidium bearing prominent glabella that is bluntly rounded anteriorly. Marginal furrow deep, narrow. Axial length of border slightly more than one-half that of brim. External surface exclusive of furrows and palpebral lobes covered with fine granules. Surface of mold pitted.

Discussion.-This species is represented by six cranidia in USGS collection $95+$-CO. It is most similar to Pseudosaratogia Tata. Wilson (1951) but differs by having a more prominent glabella, a deep marginal furrow, and finer granular ornament present only on the external surface of the cranidium. Two cranidia in USGS collection 95:-CO have the same shape as $P$. leptogrumulata, but one is nearly smooth and the other has distinct and abundant coarse and fine granules on its external surface. The specimens are questionably assigned to this species.

Occurrence: Rare, 120-150 ft above base of Dunderberg shale; unit C. USGS colln. 953-CO(?), 954-CO.

Figured specimen: Holotype cranidium, USNM 136922, USGS colln. 954-CO.

Pseudosaratogia abnormis Palmer n. sp.

Plate 11, figure 11

Diagnosis.-Specimens of Pseudosaratogia with axial length of border about one-third that of brim; border separated from brim by abrupt change in slope; length (exsagittal) of palpebral lobes about one-third length of glabella exclusive of occipital ring; surface of cranidium covered with moderately coarse grenules.

Discussion.-A single cranidium from a collection about 60 feet above that bearing $P$. leptogranulata n. sp. has the characteristic flared frontal area, narrow upturned border separated from the brim more by a change in slope than by a marginal furrow, narrow fixed cheeks, posteriorly placed palpebral lobes and granular external surface characteristic of species of Preudosaratogia. It lacks conspicuous glebellar furrows, it has a shorter palebral lobe, and the glabella is more strongly arched longitudinally then any of the Pennsylvania species described by Wilson (1951).

This species differs from $P$. leptogranulata by having shorter (sagittal) border, less well-incised marginal furrow, and stronger surface granulation.

Occurrence: Very rare, about $220 \mathrm{ft}$ above base of Dunderberg shale: unit C. USGS colln. 955-CO.

Figured specimen: Holotype cranidium, USNM 1 \&6923.

Genus and species undetermined 1

Plate 11, figures 2, 5, 6

Two cranidia from USGS collection $2297-\mathrm{CO}$ represent a trilobite unlike any other described from the Dunderberg or related faunas. It is characterized by low cranidial relief; a nearly parallel-sided squarely 
truncate glabella bearing three pairs of broad short deep slotlike glabellar furrows that are isolated from the dorsal furrows; an anteriorly flared frontal area with a narrow border of nearly constant width; and wide fixed cheeks bearing large well-defined arcuate palpebral dobes.

A third cranidium (pl. 11, fig. 5) in this collection probably is congeneric and perhaps conspecific with the forms described above. It differs from them principally by having the glabellar furrows marked by broad and shallow rather than deep depressions.

Proposal of new names is deferred until more material can be obtained to determine more clearly the relationships of these cranidia.

Occurrence: Rare, $50-60 \mathrm{ft}$ above base of Dunderberg shale; unit B. USGS colln. 2297-CO.

Figured specimen: Cranidia, USNM 136915a-c.

\section{Genus and species undetermined 2}

\section{Plate 11, figure 1}

A cranidium from USGS collection 2295-CO represents a species that is most similar to genus and species undetermined 1 . This species is characterized by low relief on the cranidium, an expanded frontal area with a narrow raised border, a straight-sided slightly tapered truncate glabella, and broad fixed cheeks bearing large well-defined arcuate palpebral lobes. It differs from genus and species undetermined 1 by having a raised rather than flattened border, an anteriorly tapered glabella, and somewhat more posteriorly placed palpebral lobes.

Occurrence: Rare, $40-50 \mathrm{ft}$ above base of Dunderberg shale; unit A. USGS colln. 2295-CO.

Figured specimen: Cranidium, USNM 136914.

\section{Genus and species undetermined 3}

Plate 11, figure 3

An incomplete but distinctive elongate pygidium from USGS collection 2297-CO cannot be assigned to any described trilobite from the Dunderberg fauna. It has a long slender well-defined axial lobe bearing $\checkmark$ ring furrows becoming shallower posteriorly; elon- gate downsloping pleural lobes bearing 6 shallow pleural furrows; and a narrow concave poorly defined border. The posterior margin is curved sharply upward and inward to the axial line forning an inverted $v$ when viewed from the rear.

This pygidium shows most similarity to that of Clitica latagenae (Wilson) from the Ore Hill limestone member of the Gatesburg formation in central Pennsylvania. It differs by possessing a narrow border and by lacking median nodes on each segment of the axial lobe.

Occurrence: Very rare, 50-60 ft above base of Dunderberg shale; unit B. USGS colln. 229i-CO.

Figured specimen: Pygidium, USNM 136916.

\section{LOCALITY INFORMATION}

The collections referred to in this parer are catalogued under 1 of 2 sets of numbers except for the collections studied by Hall and Whitfold (1877). These were listed only as coming from the Eureka district without more precise locality data. They have never been given locality numbers.

Many of the collections obtained from the Eureka district before 1900 are listed in the U.S. National Museum locality catalogue. Specimens from these collections bear green paper circles with handwritten locality numbers.

Collections since 1939 by the U.S. Geological Survey are listed by collection number in the USGS Cambrian-Ordovician locality catalogue. Specimens from these collections bear orange paper circles or rectangles with machine-printed collection numbers. USGS collection numbers referred to in the text bear the suffix "-CO" to differentiate them from a parallel series of numbers in the Silurian-Devonian (suffix "-SD") locality catalogue.

Unless otherwise indicated in the list below, the collections are from the Eureka mining district, Eureka County, Nev. Most of the geographic features that are referred to in the locality descriptions are shown on the Eureka and Pinto Summit (15-minute) quadrangles. Exact location of the measured section is shown in figure 6 .

\begin{tabular}{|c|c|c|c|}
\hline USGS collection & Locality description and collector & USGS collection & Locality description and collector \\
\hline $789-\mathrm{CO}_{-}$ & $\begin{array}{l}\text { From limestone in the Dunderberg shale, } \\
\text { about } 200 \mathrm{ft} \text { above the Hamburg dolomite. } \\
\text { In place. } 2,050 \mathrm{ft} \mathrm{S} .18 \mathrm{E} \text {. of the Hamburg } \\
\text { shaft. Elev } 8,025 \text {. Josiah Bridge, } 1939 \text {. } \\
\text { Near base of Dunderberg shale on road to } \\
\text { Catlin shaft, about } 250 \mathrm{ft} \text { from New York } \\
\text { Canyon road. In place. } 760 \mathrm{ft} \mathrm{S.} 29 \mathrm{E} \text {. } \\
\text { of the Catlin shaft. Elev } 7,480 \mathrm{ft} \text {. } \\
\text { Josiah Bridge, } 1939 \text {. }\end{array}$ & $809-\mathrm{CO}$ & $\begin{array}{l}\text { Southwest slope of Hoosac Mountain, east } \\
\text { of the high pinnacle of Hamburg dolomite. } \\
\text { East of spring in tributary of Secret } \\
\text { Canyon. In place. } 4,980 \mathrm{ft} \mathrm{S} .5 \mathrm{E} \text {. of the } \\
\text { Windfall shaft. Elev } 8,075 \mathrm{ft} \text {. Josiah } \\
\text { Bridge, } 1939 \text {. } \\
\text { North side of Widewest Canyon. } 900 \mathrm{ft} \mathrm{N} \text {. } \\
55 \text { E. of Cyanide shaft. Elev } 6,470 \mathrm{ft} \text {. } \\
\text { Josiah Bridge, } 1939 \text {. }\end{array}$ \\
\hline
\end{tabular}




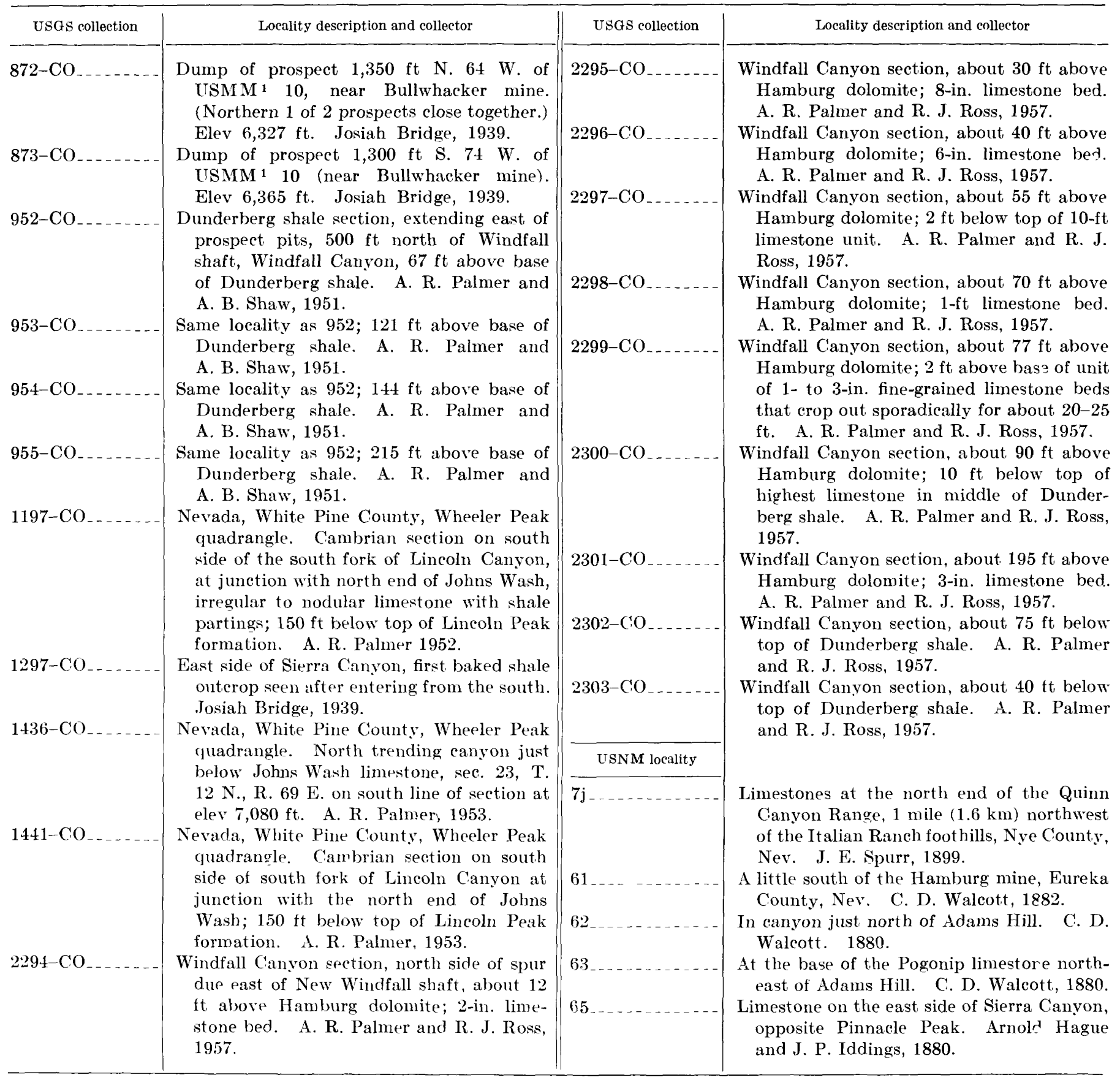

${ }^{1}$ U.S. mineral marker.

\section{REFERENCES CITED}

Barrande, Joachim, 1846, Note preliminaire sur le șstème silurien et les trilobites de Bohême: Leipzig.

Bell, W. C., Feniak, O. W., and Kurtz, V. E., 1952, Tr·ilobites of the Franconia formation, southeast Minnesota: Jour. Paleontology, v. 26, no. 2, p. 175-198.

Belt, Thomas, 1867, On some new trilobites from the Upper Cambrian rocks of North Wales: Geol. Mag., v. 4, p. 294295.

Berg, R. R., 1953, Franconian trilobites from Minnesota and Wisconsin: Jour. Paleontology, v. 27, no. 4, p. 553-568.

Berkey, C. P., 189s, Geology of the Nt. Croix Dalles: Am. Geologist, v. 21, p. $270-294$.
Bridge, Josiah, 1933, in Sellards, E. H., Adkins, W. S., and Plummer, F. B., The geology of Texas, r. 1, Stratigraphy: Texas Lniv. Bull. 3232, p. 231-234.

Bridge, Josiah, and Girty, (1. H., 1937, A redescription of Ferdinand Roemer's Paleozoic types from Texas: U.S. Geol. Surver Prof. Paper 186-M, 28 p.

Clark, T. H., 1923, A group of new species of Agnostus from Levis, Quebec: Canadian Field Naturalist, v. 37, p. 121125.

1924. The paleontology of the Beekmantown series at Levis, Quebec: Bull. Am. Paleontology, v. 10 no. 41, $134 \mathrm{p}$. 
Corda, A. J. C., 1847, in Hawle, I., and Corda, A. J. C., Prodrom einer Monographie der böhmischen Trilobiten: Böhmischen Gesell. Wiss. Abh., v. 5, p. 1-176.

Deland, C. R., and Shaw, A. B., 1956, Upper Cambrian trilobites from western Wyoming: Jour. Paleontology, v. 30, no. 3, p. 542-562.

Drewes, Harald, and Palmer, A. R., 1957, Cambrian rocks of southern Snake Range, Nevada: Am. Assoc. Petroleum Geologists Bull., v. 41, no. 1, p. 104-120.

Fisher, D. W., and Hanson, G. F., 1951, Revisions in the geology of Saratoga Springs, New York, and vicinity: Am. Jour. Sci., 5th ser., v. 249 , p. $795-814$.

Frederickson, E. A., 1948, Upper Cambrian trilobites from Oklahoma: Jour. Paleontology, v. 22, no. 6, p. 798-803. 1949, Trilobite fauna of the Upper Cambrian Honey Creek formation: Jour. Paleontology, v. 23, no. 4, p. 341363.

Hall, James, and Whitfield, R. P., 1877, Paleontology: U.S. Geol. Explor. 40th Parallel Rept., v. 4, p. 199-231.

Henningsmoen, Gunnar, 1957, The trilobite family Olenidae: Norske vidensk.-akad. Oslo Skr., no. 1, 303 p.

Hibbard, D. E., and Johnson, M. S., 1957, Geology of the Atomic Energy Commission Nevada Proving Grounds area, Nevada : U.S. Geol. Survey Bull. 1021-K, p. 333-384.

Howell, B. F., 1935, Cambrian and Ordovician trilobites from Herault, southern France: Jour. Paleontology, v. 9, p. 222238.

Howell, B. F., and others, 194i, Terminology for describing Cambrian trilobites: Jour. Paleontology, v. 21, p. 72-76.

Hupé, Pierre, 1953, Classe des trilobites, in Piveteau: Paris, Traite de Paleontologie, v. 3, p. 4t-246.

1955, ('lassification des trilobites (concluding part) : Annales Paleontologie, v. 41, p. 91-325.

Irshin, N. K., 1956, Verkhnekembriyskiy trilobity Kazakhstana, chast' I: Akad. Nauk Kazakhskoy SSR, 97 p.

Jaekel, O., 1909, Uher die Agnostiden: Deutsche Geol. Gesell. Zeitschr., v. 61, p. 380-401.

Kobayashi, Teichi, 1935, The Cambro-Ordovician formations and faunas of south Chosen-Paleontologv, Part 3: Tokyo Imp. Univ. Jour. Fac. Sci., sec. 2, v. 4, p. 49-344.

1936, The Dikelokephalininae (nov.) its distribution, migration and evolution: Japanese Jour. Geology and Geography, v. 13, no. 1-2, p. 163-178.

1937, The Cambro-Ordovician shelly faunas of South America: Tokyo Imp. Univ. Jour. Fac. Sci., sec. 2, v. 4, p. $374-522$.

1938, Upper Cambrian fossils from British Columbia with a discussion on the isolated occurrence of the socalled Olenus beds of Mt. Jubilee: Japanese Jour. Geology and Geography, v. 15, no. 3-4, p. 151-192.

1939, On the agnostids [pt. 1]: Tokyo Imp. Univ. Jour. Fac. Sci., ser. 2, v. 5, p. 69-198.

1954, On the Komaspidae: Japanese Jour. Geology and Geography, v. 24, p. 23-44.

Lake, Philip, 1906, A monograph of British Cambrian trilobites, Part 1: London, Palaeontogr. Soc., v. 60, p. 1-28.

Lochman, Christina, 1947, Analysis and revision of eleven Lower Cambrian trilobite genera: Jour. Paleontology, v. 21, no. 1, p. 59-71.

1950, Upper Cambrian faunas of the Little Rocky Mountains, Montana: Jour. Paleontology, v. 24, no. 3, p. $322-349$.

1953, Analysis and discussion of nine Cambrian trilobite families: Jour. Paleontology, v. 27, no. 6, p. 889-896.
Lochman, Christina, 1956, The erolution of some Upper Cambrian and Lower Ordovician trilobite families: Jour. Paleontology, v. 30 , no. 3 , p. $445-462$.

Lochman, Christina, and Duncan, Donald, 1944, Early Upper Cambrian faunas of central Montana: Geol. Soc. America Spec. Paper 54, 179 p.

Lochman, Christina, and Wilson, J. L., 1958, Cambrian biostratigraphy in North America: Jour. Paleontology, v. 32, no. 2 , p. $312-350$.

McAllister, J. F., 1952, Rocks and structure of the Quartz Spring area, northern Panamint Range, California: California Dept. Nat. Resources Spec. Rept. 25, 38 p.

Miller, B. M., 1936, Cambrian trilobites from northwestern Wyoming : Jour. Paleontology, v. 10, no. 1, p. 23-34.

Nelson, C. A., 1951, Cambrian trilobites from the St. Croix Valley : Jour. Paleontology, v. 25, no. 6, p. 765-784.

Nolan, T. B., Merriam, C. W., and William, J. S., 1956, The stratigraphic section in the vicinity of Eureka, Nevada: U.S. Geol. Survey Prof. Paper 276, 77 p.

Palmer, A. R., 1954, The faunas of the Riley formation in central Texas: Jour. Paleontology, v. 28, no 6, p. 709-786. 1955, Upper Cambrian Agnostidae of the Eureka district, Nevada: Jour. Paleontology, v. 29 no. 1, p. 86101.

1956a, The type species of Litocephalus Resser, 1937, (Trilobita) : Jour. Paleontology, v. 30, no. 3, p. 608-610. $1956 \mathrm{~b}$, The Cambrian system of the Great Basin in western United States, in El Sistema Caml "ico, su paleogeografia $\mathbf{y}$ el problema de su base, Internat. Geol. Cong., 20th, Mexico City 1956, Symposium, v. 2, pt. 2, p. 663-681. 1958, Morphology and ontogeny of a Lower Cambrian ptychoparioid trilobite from Nevada: Jour. Paleontology, v. 32, no. 1, p. 154-170.

Palmer, A. R., and Hazzard, John, 1956, Age end correlation of Cornfield Springs and Bonanza King formations in southeastern California and southern Nevada: Am. Assoc. Petroleum Geologists Bull., v. 40, no. 10, 2494-2499.

Rasetti, Franco, 1944, Upper Cambrian trilol ites from the Levis conglomerate: Jour. Paleontology, v. 18, no. 3, p. 229258.

Raymond, P. E., 1937, Upper Cambrian and Lower Ordovician Trilobita and Ostracoda from Vermont: Geol. Soc. America Bull., v. 48, no. 8, p. 1079-1146.

Resser, C. E., 1935, Nomenclature of some Cambrian trilobites : Smithsonian Mise. Colln., v. 93, no. 5, $46 \mathrm{r}$ 1936, Second contribution to nomenclature of Cambrian trilobites: Smithsonian Misc. Colln., v. 95, no. 4, 29 p. 1937, Third contribution to nomenclsture of Cambrian trilobites: Smithsonian Misc. Colln., v. 95, no. 22, $29 \mathrm{p}$.

1938, Cambrian system (restricted) of the southern Appalachians: Geol. Soc. America Spec. Paper 15, 140 p. 1942a, Fifth contribution to nomenclature of Cambrian fossils: Smithsonian Misc. Colln., v. 101, no. 15, 58 p. 1942b, New Upper Cambrian trilobite: : Smithsonian Misc. Colln., v. 103, no. 5, 136 p.

Roemer, Ferdinand, 1849, Texas, mit besondere deutsche Auswanderung und die physischen Verhältnisse des Landes: Bonn, $464 \mathrm{p}$.

18.52. Die Kreidebildungen von Texas und ihre organischen Einschliisse: Bonn, 100 p.

Ross, R. J., 1951, Ontogenies of three Garden City (early Ordovician) trilobites: Jour. Paleontology, v. 25, no. 5, p. 578-586. 
Shaw, A. B., 1951, The paleontology of northwestern VermontI, New Late Cambrian trilobites: Jour. Paleontology, v. 25, no. 1, p. $97-114$.

1952, Paleontology of northwestern Vermont-II, Fauna of the Upper Cambrian Rockledge conglomerate near st. Albans: Jour. Paleontology, v. 26, no. 3, p. 458483.

Shimer, H. W., and Shrock, R. R., 1944, Index fossils of North America: Technology Press, Massachusetts Inst. of Technology ; New York, John Wiley \& Sons, 837 p.

Shumard, B. F., 1861, The primordial zone of Texas, with descriptions of new fossils: Am. Jour. Sci., 2 d ser., v. 32, p. 213-221.

Tullberg, s. A., 1880, Om Agnostus arterna i de Kambriska aflagringarne vid Andrarum: Sveriges Geol. Undersökning, ser. C, no. $42,37 \mathrm{p}$.

Walcott, C. D., 1884, Paleontology of the Eureka district: U.S. Geol. Survey Mon. 8, p. 1-64.

1912, New York Potsdam-Hoyt fauna: Smithsonian Misc. Colln., v. 5T, no. 9, p. 251-304. 1916, Cambrian trilobites: Smithsonian Misc. Colln., v. 64 , no. 5 , p. $303-456$.

1924, Cambrian geology and paleontology-V, No. 2, Cambrian and Lower Ozarkian trilobites: Smithsonian Misc. Coll., v. 75, no. 2, p. 53-60.

1925, Cambrian geology and paleontology-V, No. 3, Cambrian and Ozarkian trilobites: Smithsonian Misc. Colln., v. 75 , no. 3, p. 61-146.

Walcott, C. D., and Resser, C. E., 1924, Trilobites from the Ozarkian sandstones of the island of Novaya Zemlya, in Report of the scientific results of the Norwegian expedition to Novaya Zemlya: Oslo, Vidensk.-selsk. Kristiania, no. 24 , p. 1-14.
Warburg, Elsa, 1925, The trilobites of the Leptaena limestone in Dalarne: Geol. Inst. Upsala, Bull., v. 17, p. 1-44\%.

Westergard, A. H., 1922, Sveriges olenidskiffer : Sveriges Geol. Undersökning, ser. Ca, no. 18, p. 1-205. 1946, Agnostidea of the Middle Cambrian of Swerlen : Sveriges Geol. Undersökning, ser. C, no. 477, Arst ok 40, no. 1, p. 1-140.

1947 , Supplementary notes on the Upper Cambrian trilobites of Sweden: Sveriges Geol. Undersökning, ser. C, no. 489, p. $1-34$.

1948, Non-agnostidean trilobites of the Middle Cambrian of Sweden. I. : Sveriges Geol. Undersökning, ser. C, no. 498 , p. 1-32.

1953, Non-agnostidean trilobites of the Middle Cambrian of Sweden-[pt.] 3: Sveriges Geol. Undersïkning, ser. C, no. 526, p. 1-58.

Whitehouse, F. W., 1936, The Cambrian faunas of northeastern Australia-Parts 1 and 2: Queensland Mus. Mem. v. 11, p. $59-112$.

1939, The Cambrian faunas of northeastern Australia -Part 3, The polymerid trilobites: Queensland Mus Mem., v. 11, p. $179-282$.

Whittington, H. B., and Evitt, W. R., II, 1954, Silicified Middle Ordovician trilobites: Geol. Soc. America Mem. 59, 107 p.

Wilson, J. L., 1948, Two Upper Cambrian Elvinia zone t"ilobite genera: Jour. Paleontology, v. 22, no. 1, p. 30-34. 1949, The trilobite fauna of the Elvinia zone in the basal Wilberns limestone of Texas: Jour. Paleortology, v. 23, no. 1, p. $25-44$. 1951, Franconian trilobites of the central Appalachians: Jour, Paleontology, v. 25, no. 5, p. 617-654.

1954, Late Cambrian and Early Ordovician tr' lobites from the Marathon Uplift, Texas: Jour. Paleontolngy, v. 28 , no. 3 , p. 249-285. 



\section{INDEX}

[Italic numbers indicate descriptions]

A

abnormis, Pseudosaratogia

Acknowledgments .

Acrocephalaspis.

acuminata, Bynumiell

acutus, Homagnostus.

Pseudagnostus

affinis, Kindbladia

Agnostus. .

cyclopyge

pisiformis.

obesus.

alata, Prehousia

alper sensis, Iddingsia.

anatina, Iddingsia.

Plataspella.

Anechocephalus.

trigranulatus.

Angulotreta triangularis

angustilimbatus, Irvingella (Parairringella)

anyta, Dunderbergia.

Crepicephalus (Loganellus)

Aphelaspidinae

Aphelaspis.

tumifrons.

A phelaspis zone...

asiatica, Pterocephali

Maladindes.

B

Battus bibullatus

Bell, W. C., quoted

Berkeia

comes.

nevadensis.

tyrica....

wichitaensis.

bibullatus, Battus.

bicincta, Iddingsin

bigranulosa, Dunderbergia

bilobata, Pterocephalina.

bilobatus, Dikellocephalus.

Litocephalus.

Brachiopods.

breniceps, Oligometopus.

Ptychoparia (Solenopleura)

bridgei, Pterocephalia .

briscoensis, Bynumiella

buttsi, Cheilocephalus.

Bynumeilla.

acuminata

briscoensis

typicalis...

Bynumina.

caelata

globosa

missouriensis.

terrenda...

C

caelata, Bynumina

canadensis, Dunderbergia.

Housia.

Catlin memher of the Windfall formation

Ceraurinella typa

Cernuolimbus

depressus.

orygmatos. -

semigranulosus

$80-81,82-84$

6. $64,78,80,90$

80.81 .90

Page
pl. 11

Cliffa latagenae

Page

102

Collecting localities, description $\ldots \ldots \ldots$.

Collectors, names.

comes, Berkeia

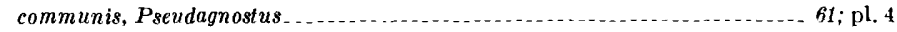

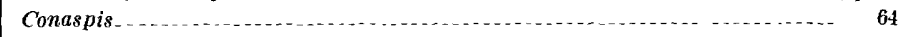

concava, Iddingsia
Pterocephalia...... 96

conservafor, Minupeltis. _....... 98; pl. 10

constricta, Parahousia

convexa, Dunderbergia

converimarginatus, Labiostria

Crassifimbra

crassimarginata, Iddingsia

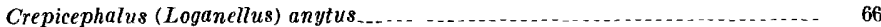

granulosus $\ldots \ldots$

maculosus $\ldots . .66$

nitidus...

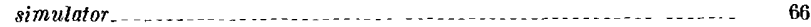

unisculcatus

cyclopyge, Agnostus.

Davis formation, Missouri.......

Deadwoodia duris . ...

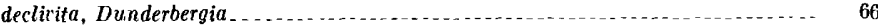

Dellea wilbernsensis. ...

depressus, Cernuolimbus........ 85

Dicellocephalus rich mondensis . . ... . . . . . . .

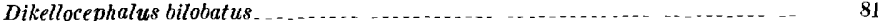

Dikelocephalites flabelliformis . . . .

Dokimocephalus

gregori

pernasutus..................... 11

Dolichometopus (Housia) varro

Dunderberg shale, description $\ldots \ldots \ldots 56$

lithic units . .

measured section.

Dunderbergia $\ldots \ldots \ldots 6,56,58,60,64,65-66,67,6869,72,75$

anyta

bigranulosa $\ldots$.

canadensis . . . .

convexa

declivita

granulosa

halli

maculosa ...

nitida $\ldots . . . \ldots 6,60,66,87,68$ pl. 4

polybothra .................. $60,65,66,67-68,82 ; \mathrm{pl} .5$

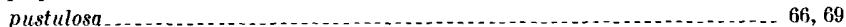

quadrata $\ldots$.

simulator.... 66,67

suada $\ldots 6$

variagranula

vermontensis . . .

Dunderbergia zone

Drumaspis ................ 64

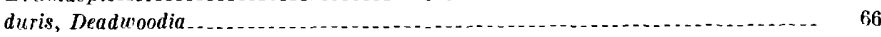

Elburgia

E

granulata

$64,65,66,68-69,71,72$

granulosa

69, $71 ;$ pl. 6

guinnensis

elongata, Pteroce phalia $\ldots \ldots, 88 ; \mathrm{pl} .9$

Elvinia $\ldots \ldots \ldots, 64,65,68,69,7_{10}, 71,72,89$

granulata ......

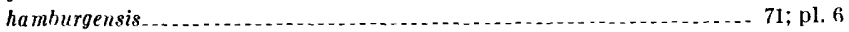

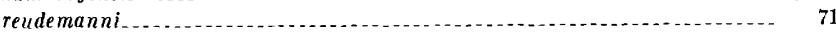

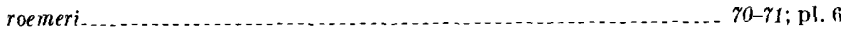

ufahensis

sp 
Page

Elvinia zone $\ldots \ldots \ldots \ldots \ldots \ldots, 75,80,81,8$ Elviniella

laevis

$71,72,74 ; \mathrm{pl}, 6$

Elviniidae $\ldots . . . . . . .59,60,64-65,66-74,80,81,96$

eurekensis, Irvingella (Parairtingella)

74 ; pl. 6

expansa, Taenora.

83,84 ; pl. 7

Feniak, o. W., quoted

flabelliformis, Dikelocephalites

Generic groupings

Genevievella

Genus and species undetermined 1

3.

Geographic distribution, Dunderberg shale

Geragnostinae

Geragnostus

gladiator, Macropyge

glandiforme, Phalacroma

globosa, Bynumina

granulata, Elburgia

Elninin

granulatus, Olenus

granulomarginatus, Lifocephalus

granulosa, Dunderbergia

Elburgia

granulosus, Crepicephalus (Loganellus)

grata, Pterocephalina.

Sigmocheilus .

gregori, Dokimocephalus

Grönwallia.

H

halli, Dunderbergia.

Housia.

Hamburg dolomite

hamburgensis, Elrinia

Parairvingella.

Henningsmoen, Gunnar, quoted

Homagnostus.

acutus

obesus....

tumidosus

Housia

canadensis

halli.

racuna

narro.

(IIousia) varro, Dolichometopus

Housiidae .

Hypostomes, characteristics unidentified

$64,74,75-78,98,99$

$56,75,94:$ pl. 10

$70,71, . \mathrm{pl} .6$

$79-80:$ pl. 6

58, 82; pl. 8

69,$71 ;$ pl. 6

Iddingsia

alpersensis

anatina.

bicincta

concara

crassimarginata

missouriensis

neradensis

occidentalis

quinnensis

rolusta.

similis

simplicitas

utahensis

intermedia, Parairringelle

Irringella

Irvingella (Irvingella) major.. major

(Iri ingella), Iringella

major, Irvingella

Irringella (Parairringella) anqustilimbatus

eurekensis

suecica.

Irvingellina

60-61; pl. 11

74,96
Kindbladia
affinis

Page

retusa

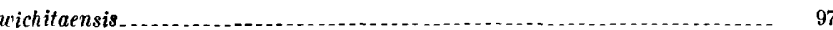

Komaspidae.

Komaspis typa

Kurtz, V. E., quoted

Labiostria conteximarginatus. platifrons.

sigmoidalis.

laeris, Elriniella

lata, Pseudosaratogia

latagenae, Cliffa.

latue, Pinctus

leptogranulata, Pseudosaratogia $\ldots . . . .101$; 11

Lincoln Peak formation, Snake Range, Nev . . . . . . . . . . . . . . . . . . . . 56, 78, 103

Linnarssonella

List of collections

Litocephalus

$102-103$

bilobatus $58,81,82,90$; pl. $?$

gran ulomarginatus .............

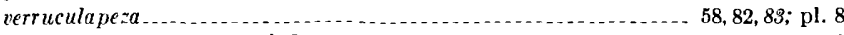

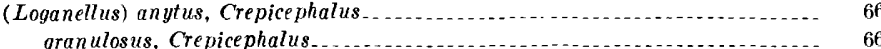

granulosus, Crepicephalus........
maculosus, Crepicephalus . 66 .

nitidus, Crepicephalus _. 6566,67

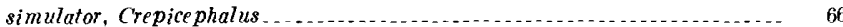

unisculcatus, Crepicephalus ........ 71

longispina, Morosa

M

Macropyge gladiator

maculosus, Crepicephalus (Loganellus) _. . . . 66.75

magna, Pseudosaratogia. .............. 101

major, Irringella

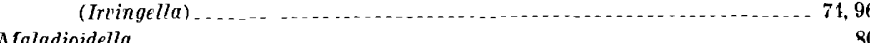

Maladioidella. -

Maladioides.

asiaticus

Meteoraspis minuta

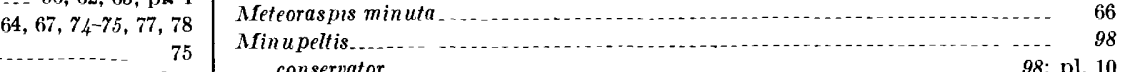

minuta, Meteoraspis

missouriensis, Bynumina

Iddingsia.

66

Morosa

longispina.

$56,82,98,99-109,101 ;$ pl. 10

Nericia

quinguidentata.

septemdentata

neradensis, Berkeia.

Iddingsia...

nitida, Dunderbergia

nitidus, Crepice phalus (Loganellus)

Nopah formation.

notha, Pteroce phatina..

o

obesus, . 1 gnostus pisiformis

Homagnostus

occidens, Pterocephalia

occidentalis, Iddıngsia

Olenidae.

Oleninae.

Olenus.-

granulatus

wilsoni.

Oligometopus

brericeps

Ontogeny, discussion

Ore Hill limestone member of Gatesburg formation

Ornamentation, kinds

Orr formation

orygmafos, Cernuolimbus

otata, Housia.
$56,64,73,96$
73,$74 ;$ pl, 6

- 74: pl. 6

73
_... 7 
$\mathrm{P}$

Pagodia

Parabolina.

Parabolizoididae

Paracoosia

Parahousia constricta.

Purairringella...

ha mburgensis intermedia

(Parairvingella) angustilimbatus, Iroingella eurekensis, Irtingella

Irvingella

suecica, Irvingella.

Parasolenopleura

pernasutus, Dokimocephalus Plychoparia

Page

100

87

$74,76-77,78$

$56,76,7 \%$; pl. 7

73,74

73

73,$74 ; \mathrm{pl} .6$

74; pl. 6 $56,64,73,96$ 57

95 ; pl. 11

Phalacroma...

glandiforme

sp

Pinctus.

latus..

spp.

pisiformis, Agnostus

obesus, . 1gnostus

Platas pella.

anatina

platifrons, Labiostria

Taenora..

pogonin pensis, Pterocephalina

Sigmochellus

polybothra, Dunderbergia

Post-A phelaspis zone

Prehousia.

alata

semicircularus.

Preparation of specimens for study

Principles of classification

Proceratopyge
prolongus, Pseudagnostus

Pseudagnostus

acutus.-

communis

prolongus

Pseudosaratogia abnormis.

lata.

le ptogranulata

magna.

Pteroce phalia

asiatica..

bridger.

concaba.

elongata.

occidens.

sanctisabae.

Pteroce phaliidae.

Pterocephaliinae.

Pteroce phalina

bilobata.

grata

pogonin pensis

texana...

Pterocephalops.

Ptychaspis pustulosa

Ptychoparia pernastus

similis.

robusta..

(Solenopleura) breviceps

suada.

Ptychoparioidea.

pustulosa, Dunderhergia

Ptychaspis.

55
$57-59,92$

(15

61,62

$62 ; p], 4$

$61 ; \mathrm{pl} .4$

$61 ; \mathrm{pl} .4$

$101 ;$ pl. 11

101; pl. 11

$56,61,80,81,85,86-88,89,90$

87

$88 ;$ pl. 9

60,$83 ;$ pl. 9

87,88

$86,87,89-89 ;$ pl. 9

$59,60,74,78,80,81-92$

$60,80,81,84.85-92$

\section{0}

0

$\mathbf{R}$

Page

Ranges of trilobites in Dunderberg shale_..
Resser, C. E., quoted.

Resser, C. E., quoted..
retusa, Kindbladia.

reudemanni, Elvinia

richmondensis, Dicellocephalus

robusta, Iddingsia

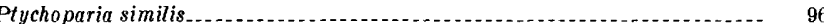

roemeri, Elvinia

vacuna, Housia variagranula, Dunderbergia.. .64 varro, Dolichometopus (Housia)

vermontensis, Dunderbergia verruculapeza, Litoce phalus

$$
\text { , }
$$

quadrata, Dunderbergia

- 66, 68; pl. 4 quinnensis, Elburgia 6i8, $69-7 \% ;$ pl. 6

Taenice phalus

quinquedentata, Nericia.

cing

Kindbladia
wilbernsensis, Dellea
Wilson, J. L., quoted
wilsoni, Olenus

Windfall formation unisculcatus, Crepicephalus (Loganellus) .............................. 71

Sigmocheilus........ $90,91-92 ;$ pl. 9

\section{$\mathrm{V}$}

Housia

semigranulosus, Cernuolimbus.............

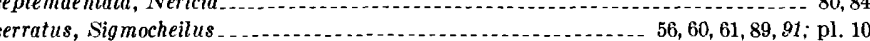

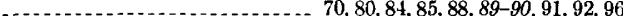

erratus _............. 56,60,61,89,91; pl. 10

moidalis, Labiostria

Ptychoparia 96,97

robusta, Ptychoparia

mulator, Crepicephalus (Loganellus)

Dunderbergia . ...... 66,67

Solenopleaura) breviceps, Ptychoparia

Stenelymus

da, Dunderbergia

Ptychoparia.
cica, Irvingella (Parairvingella)

uprageneric groupings

Sutures, ventral cephalic.

quinnensis 70

expansa

platifrons

prms, morphologic

terrenda, Bynumina

riangularis, Angulotreta ...

tumidosus, Homagnostus..........

$\begin{array}{ll}\text { Chariocephatus } & 74 \\ --- & 73\end{array}$

pa, Ceraurinella

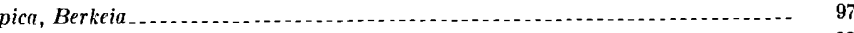

picalis, Bynumiella

\section{W}

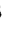

pogonipensis . . . . . . . . . . . . . . $60, s 1 ;$ pl. 10 

PLATES 4-11 


\section{PLATE 4}

Figures 1, 2. Homagnostus tumidosus (Hall and Whitfield) (p. 63), $\times 10$.

1. Cephalon, USNM 136831a, USGS colln. 2299-CO.

2. Pygidium, USNM r36831b, USGS colln. 2299-CO.

3, 4. Pseudagnostus communis (Hall and Whitfield) (p. 61), $\times 10$.

3. Cephalon, USNM 136832a, USGS colln. 2299-CO.

4. Pygidium, USNM 136832b, USGS colln. 2299-CO.

5, 6. Pseudagnostus prolongus (Hall and Whitfield) (p. 61).

5. Cephalon, $\times 10$, USNM 136833a, USGS colln. 2301-CO.

6. Pygidium, $\times 8$, USNM 136833b, USGS colln. 2301-CO.

7-9. Homagnostus obesus (Belt) (p. 63), $\times 10$.

7. Cephalon, USNM 136834a, USGS colln. 2296-CO showing finely pitted outer surface.

8. Pygidium, USNM 136834b, USGS colln. 2296-CO.

9. Cephalon, USNM 136835, USGS colln. 2295-CO.

10-12. Pseudagnostus? acutus (Kobayashi) (p. 62), $\times 10$.

10. Lectotype pygidium, NMC 11996, from so-called Parabolinella limestone, east of Harrogate, British Columbia, Canada. Specimen figured by Kobayashi (1938, pl. 16, fig. 18).

11. Pygidium, USNM 136836a, USGS colln. 2297-CO, showing muscle scars.

12. Pygidium, USNM 136836b, USGS colln. 2297-CO.

13. Phalacroma? sp. (p. 63), $\times 10$.

Cephalon, USNM 136837, USGS colln. 2300-CO.

14-21, 23, 24. Dunderbergia nitida (Hall and Whitfield) (p. 67).

14. Pygidium, $X 4$, USNM 136838a, USGS colln. 2300-CO.

15. Lectotype cranidium, $\times 3$, USNM 24572, Dunderberg shale, Eureka, Nev.

16. Paratype cranidium, $\times 3$, USNM 24572b, Dunderberg shale, Eureka, Nev.

17. Cranidium, holotype of $D$. simulator (Hall and Whitfield), $\times 1$, USNM 24575, Dunderberg shale, Eureka, Nev.

18. Latex cast of exfoliated cranidium, $\times 3$, USNM 136838b, USGS colln. 2300-CO.

19. Stereogram of cranidium, $\times 4$, USNM 136838c, USGS colln. $2300-$ CO.

20. Latex cast of underside of right free cheek showing form of doublure, $\times 3$, USNM 136839 , USGS colln. 873-CO.

21. Latex cast of right free cheek, $\times 3$, USNM 136838d, USGS colln. 2300-CO.

23. Pygidium, $\times 3$, USNM 136838e, USGS colln. 2300-CO.

24. Exfoliated right free cheek showing fine-pitted surface, $\times 4$, USNM 136838f, USGS colln. 2300-C.O.

$22,25,28,29$. Dunderbergia variagranula Palmer (p. 68).

22. Stereogram of cranidium, $\times 4$, USNM 136840a, USGS colln. 2297-CO.

25. Cranidium, $\times$ 4, showing coarse granules on surface of internal mold of glabella, USNM 136841, USGS colln. 2298-CO.

28. Pygidium, $\times 4$, USNM 136843, USGS colln. 809-CO.

29. Free cheek, $\times 4$, USNM 136840b, USGS colln. 2297-CO.

26. Dunderbergia variagranula? Palmer (p. 68), $\times 8$.

Cranidium, questionably assigned to this species, USNM 136842, USGS colln. 2302-CO.

27. Dunderbergia quadrata Kobayashi (p. 68), $\times 2$.

Cranidium, NMC 11962, west of Harrogate, British Columbia, Canada. 
GEOLOGICAL SURVEY

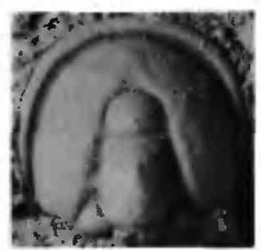

1

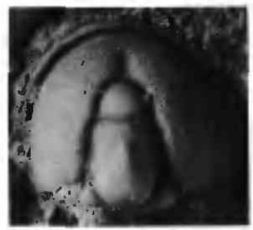

7

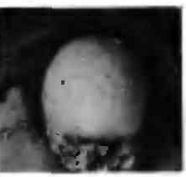

13

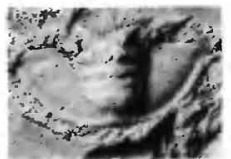

14

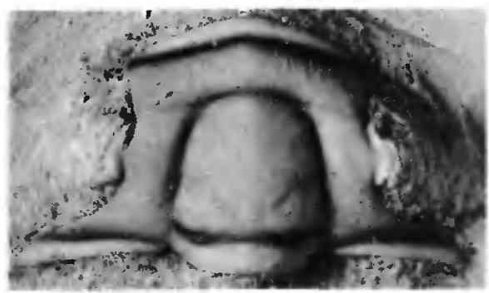

19

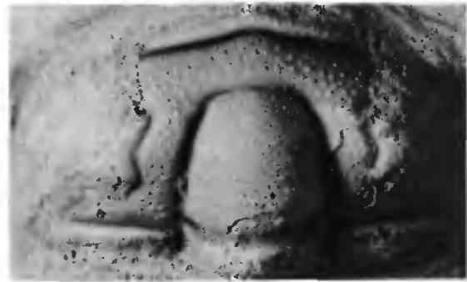

22

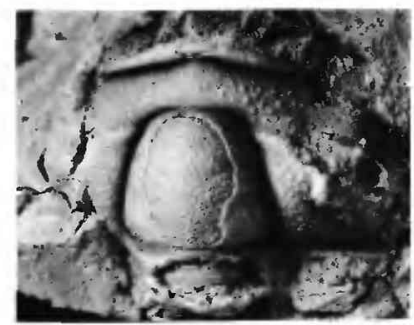

25

2

8

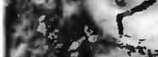

15
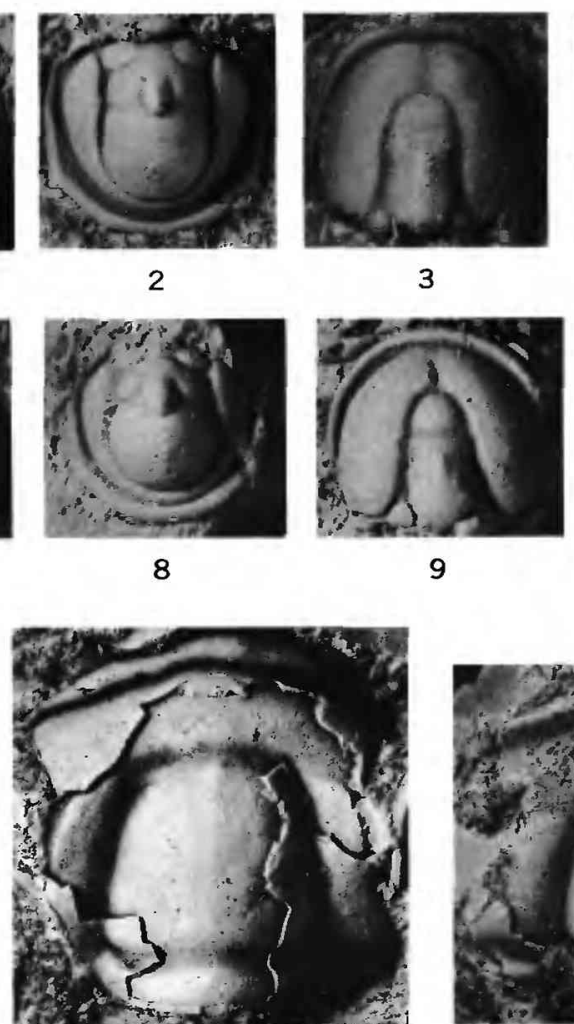

9

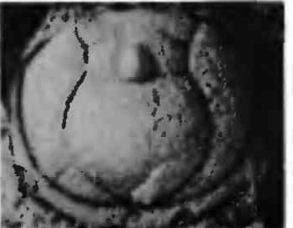

10

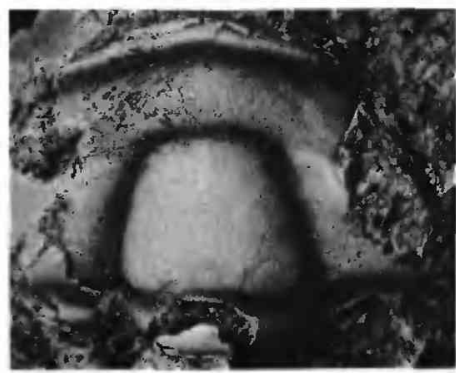

16
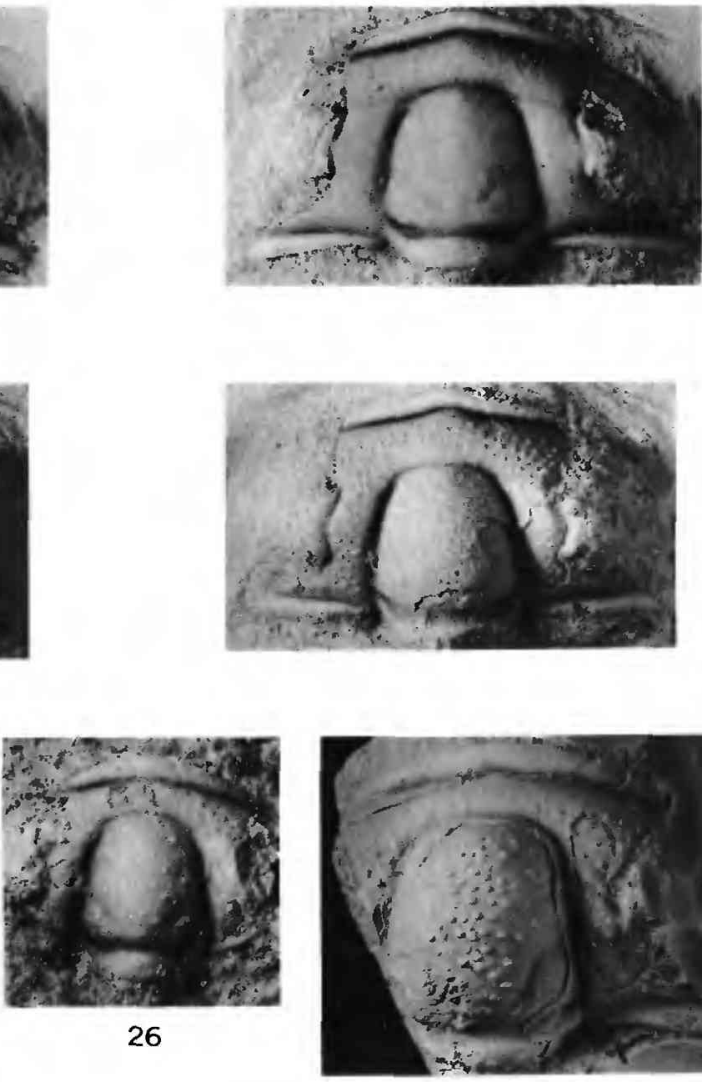

PROFESSIONAL PAPER 334 PLATE 4

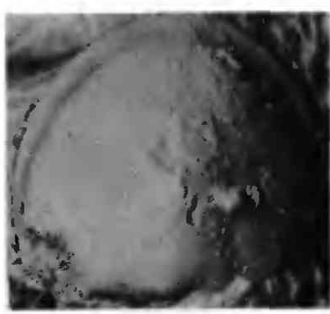

5

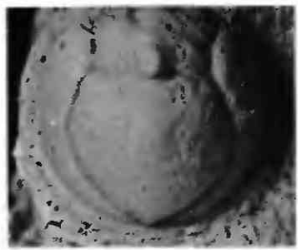

11

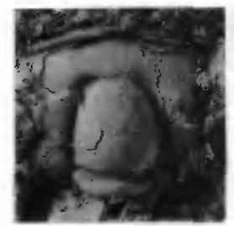

17
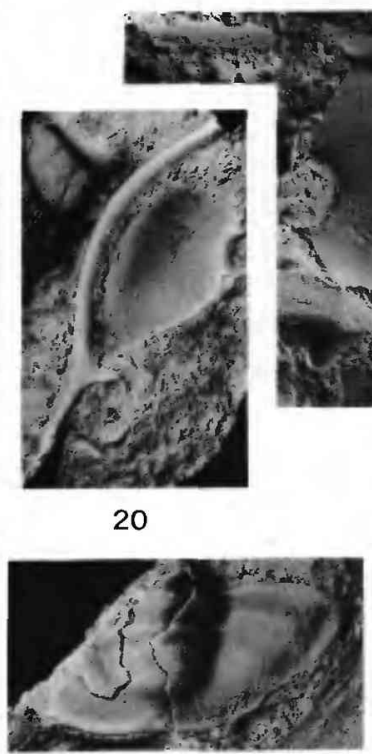

23

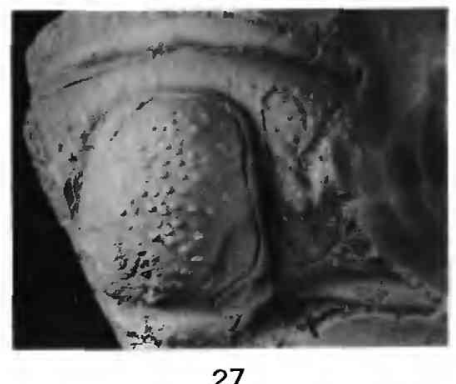

28

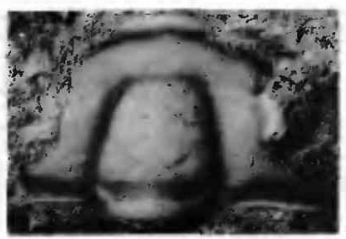

18

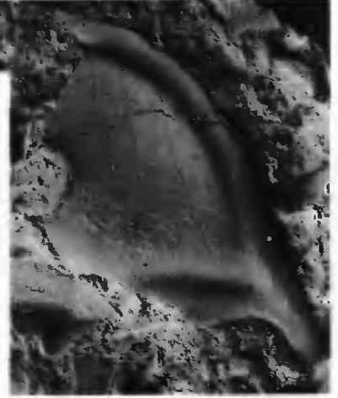

21

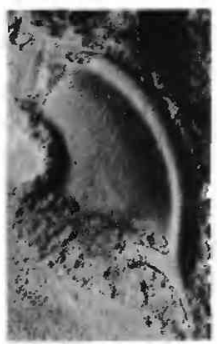

24

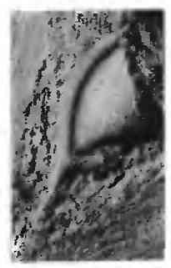

29

AGNOSTIDAE AND ELVINIIDAE 
GEOLOGICAL SURVEY

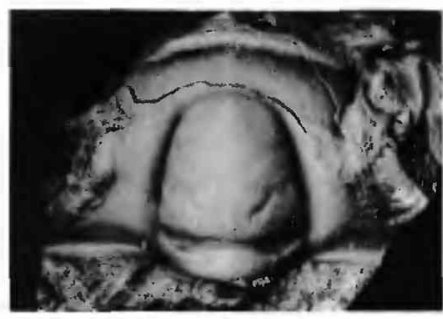

1

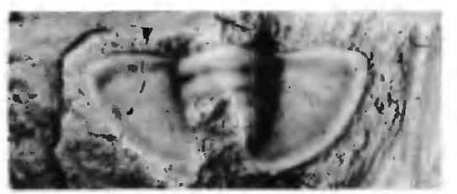

6

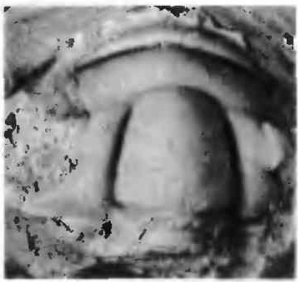

9

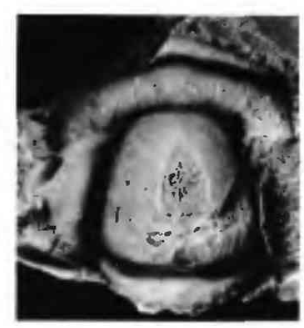

10

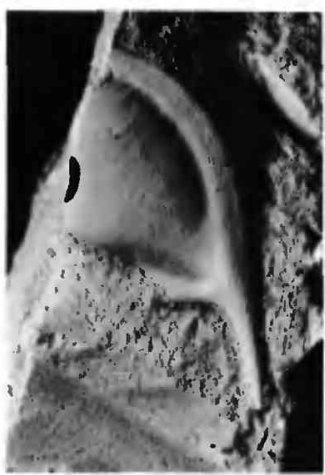

2

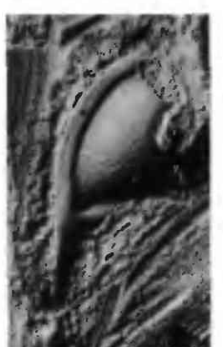

3
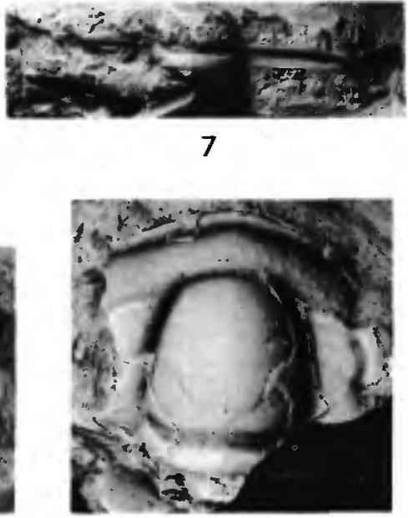

11

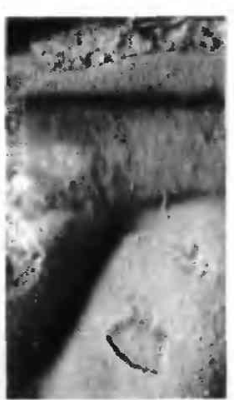

13

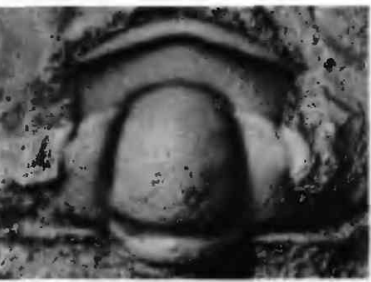

18

PROFESSIONAL PAPER 334 PLATE 5

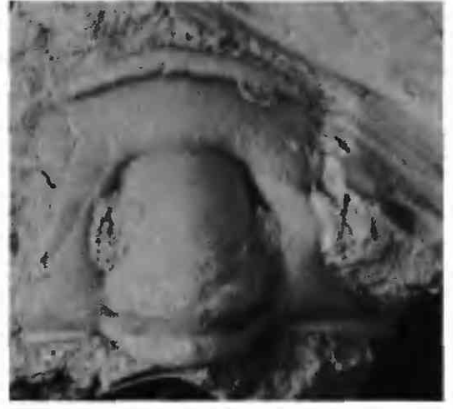

12

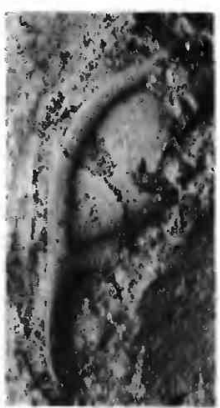

15

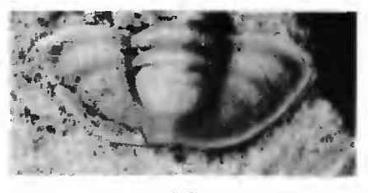

20

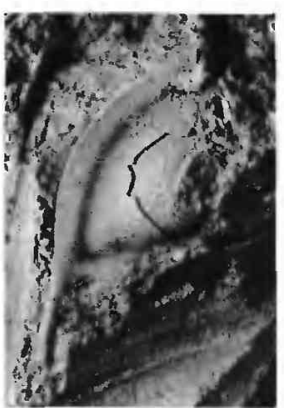

16

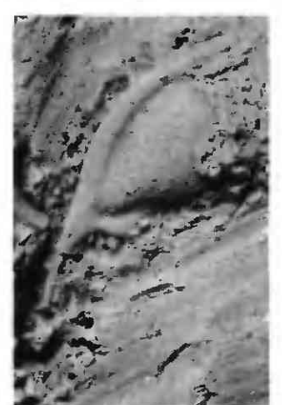

17

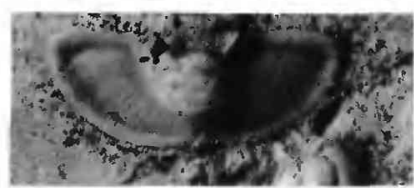

21

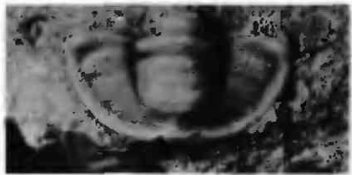

22

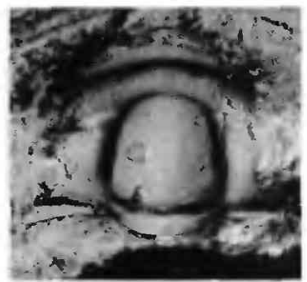

19

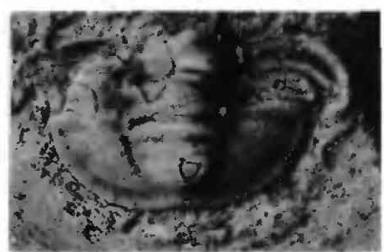

23

ELVINIIDAE 


\section{PLATE 5}

Figures 1-4, 6, 7, 9, 14. Dunderbergia polybothra n. sp. (p. 67).

1. Cranidium, $\times 3$, USNM 136844a.

2, 3. Free cheeks, $\times 4$, USNM $136844 b$, c.

4, 7. Thoracic segments, $\times 3$, USNM $136844 \mathrm{~d}$, e.

6. Pygidium, $\times 3$, USNM $136844 \mathrm{f}$.

9. Stereogram of holotype cranidium, $\times 4$, USNM 136845.

14. Detail of top surface of glabella and occipital ring, of cranidium in fig. $1, \times 10$. All specimens from USGS colln. 2296-CO.

5. Dunderbergia maculosa (Hall and Whitfield) (p. 66), $\times 1$.

Holotype cranidium, USNM 24617 Dunderberg shale, Eureka district, Nevada.

8. Dunderbergia pustulosa (Hall and Whitfield) (p. 66), $\times 1$.

Holotype cranidium, USNM 24579 Dunderberg(?) shale, White Pine district, Nev.

10-13, 15-23. Dunderbergia bigranulosa n. sp. (p. 66).

10. Cranidium, $\times 4$, USNM 136846a, USGS colln. 795-CO.

11. Exfoliated cranidium, $\times 3$, USNM 136846 b, USGS colln. $795-\mathrm{CO}$.

12. Stereogram of holotype cranidium, $\times 3$, USNM 136847, USGS colln. 2295-CO.

13. Detail of surface of brim and border of cranidium in fig. $19, \times 10$.

15. Free cheek, $\times 4$, USNM 136848b, USGS colln. 2295-CO.

16. Free cheek, $\times 4$, USNM 136849a, USGS colln. 2294-CO.

17. Free cheek, $\times 5$, compare border with fig. 16, USNM $136848 \mathrm{c}$, USGS colln. 2295-CO.

18. Cranidium, $\times 4$, USNM 136848a, USGS colln. 2295-CO.

19. Cranidium, $\times 4$, USNM 136849b, USGS colln. 2294-CO.

20. Pygidium, $\times$ 4, USNM 136849c, USGS colln. 2294-CO.

21, 22. Pygidia, $\times$ 4, USNM 136848d, e, USGS colln. 2295-CO.

23. Pathologic pygidium with partly attached, distorted thoracic segments, $\times 3$, USNM 136848f, USGS colln. 2295-CO. 


\section{PLATE 6}

Frgure 1. Irvingella (Parairvingella) eurekensis (Resser) (p. 74), $\times 3$.

Stereogram of holotype cranidium, USNM 108668, USNM loc. 61.

2, 3. Irvingella (Parairvingella) angustilimbatus Kobayashi (p. 73), $\times 2$.

2. Stereogram of small plesiotype cranidium for comparison with $I$. (P.) eurekensis, USNM 108672, USNM loc. 62.

3. Large cotype cranidium, USNM 24643, USNM loc. 63.

4. Elvinia granulata Resser (p. 71), $\times 2$.

Stereogram of holotype cranidium, USNM 108815, USNM loc. 63.

5. Elvinia hamburgensis (Resser) (p. 71), $\times 2$.

Holotype cranidium, USNM 108669, USNM loc. 61.

6. Elvinia? sp. (p. 71) $\times 3$.

Cranidium, USNM 136850, USGS colln. 2300-CO.

7. Elvinia roemeri (Shumard) (p. 70), $\times 2$.

Cranidium, USNM 136851, USGS colln. 789-CO.

8, 14. Elviniella sp. (p. 72), $\times 4$.

8. Stereogram of cranidium, USNM 136852, USGS colln. 954-CO.

14. Cranidium, USNM 136853, USGS colln. 2301-CO.

9, 10. Elviniella laevis n. gen., n. sp. (p. 72), $\times 4$.

9. Stereogram of holotype cranidium, USNM 136854a, USGS colln. 952-CO.

10. Latex cast of posterior part of holotype cranidium USNM $136854 \mathrm{~b}$.

11-13, 15. Elburgia quinnensis (Resser) (p. 69).

11. Stereogram of exfoliated holotype cranidium, $\times 3$, USNM 108838a, USNM loc. 7 j.

12. Cranidium on same block as holotype, $\times 3$.

13. Cranidium, $\times 4$, USNM 136855a, USGS colln. 2298-CO.

15. Exfoliated cranidium, $\times 3$, USNM 136855b, USGS colln. 2298-CO.

16, 17, 19. Elburgia granulosa (Hall and Whitfield) (p. 69), $\times 3$.

16. Cranidium, USNM 136856, USGS colln. 795-CO.

17. Cranidium, USNM 136857, USGS colln. 2297-CO.

19. Stereogram of holotype cranidium, USNM 24573, Dunderberg shale, Eureka district, Nevada.

18, 20-22. Olenus? wilsoni Henningsmoen (p. 79), $\times 5$.

18. Cranidium, USNM 136858a, USGS colln. 2300-CO.

20. Cranidium, USNM 136859a, USGS colln. 2297-CO.

21. Free cheek, USNM 136859b, USGS colln. 2297-CO.

22. Pygidium, USNM 136858b, USGS colln. 2300-CO.

23-27. Olenus? granulatus n. sp. (p. 79).

23. Pygidium, $\times 5$, USNM 136860, USGS colln. 2299-CO.

24. Stereogram of holotype cranidium, $\times 5$, USNM 136861, USGS colln. 2300-CO.

25. Detail of surface, holotype cranidium, $\times 15$.

26. Cranidium, USNM 136862, USGS colln. 795-CO.

27. Detail of surface of pygidium, $\times 15$. 
GEOLOGICAL SURVEY

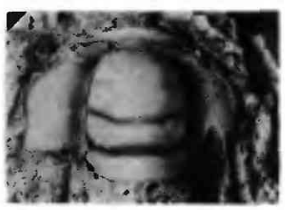

1

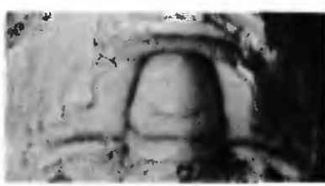

4
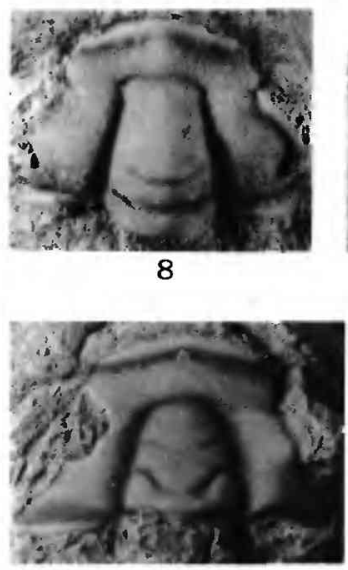

11

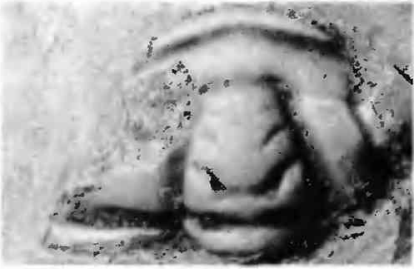

15
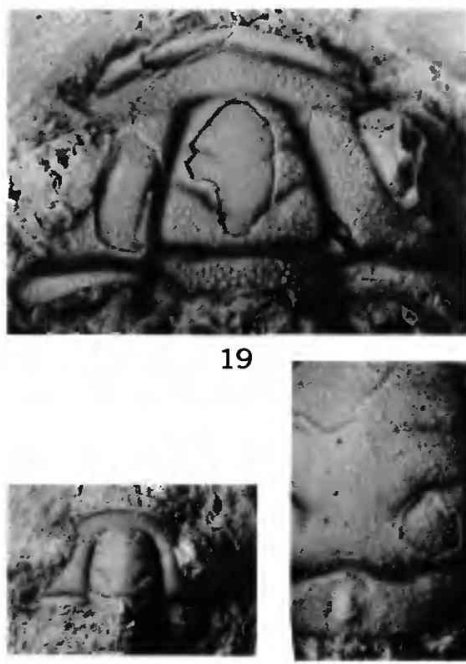

24

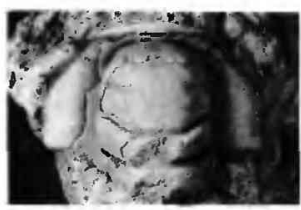

2
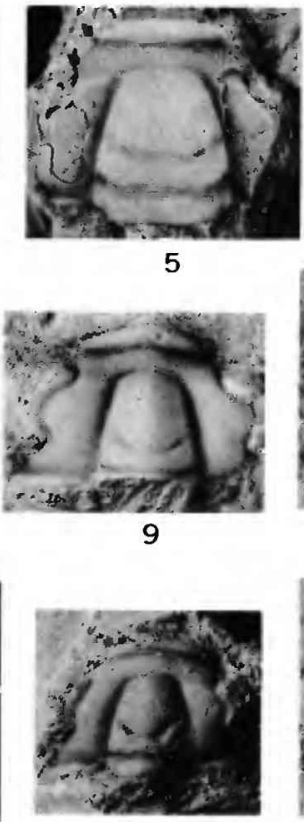

12
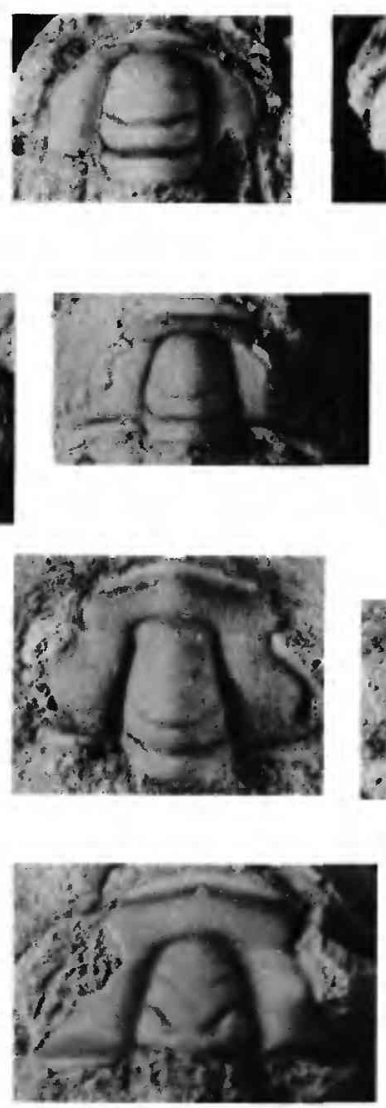
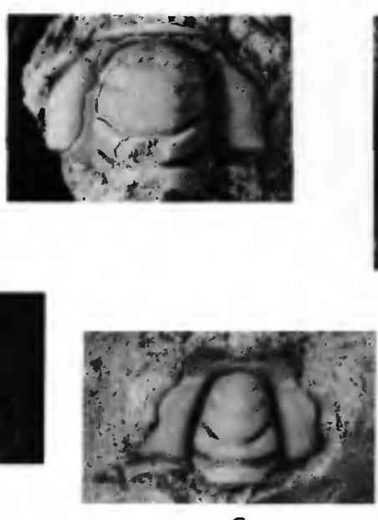

6
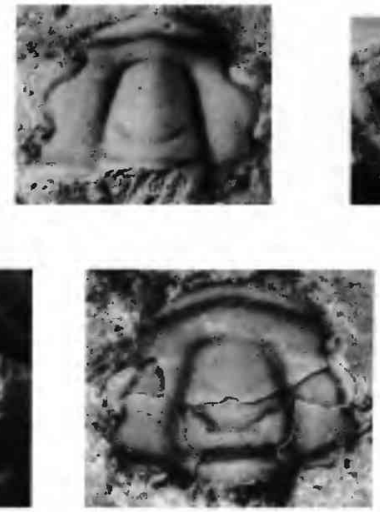

13
PROFESSIONAL PAPER 334 PLATE 6

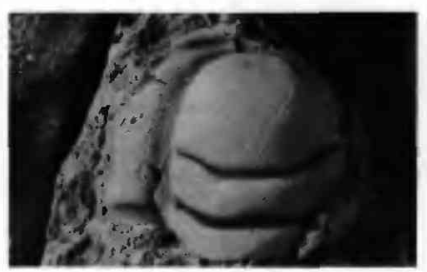

3
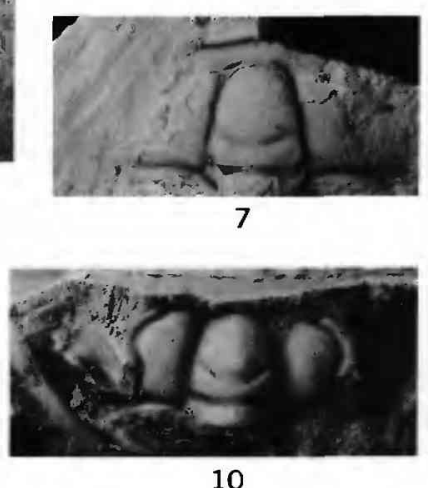

10

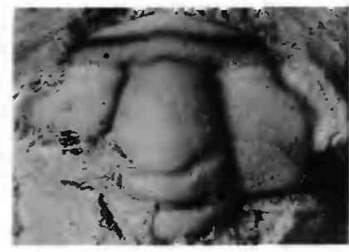

14

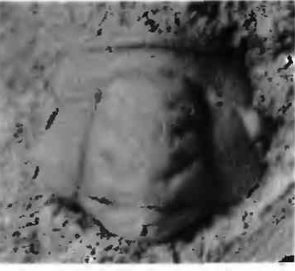

18
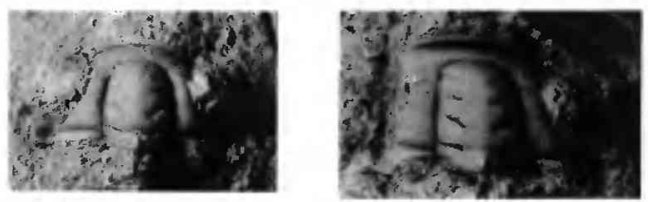

26

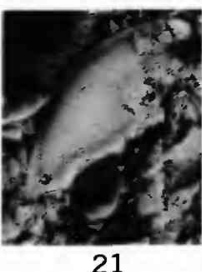

21

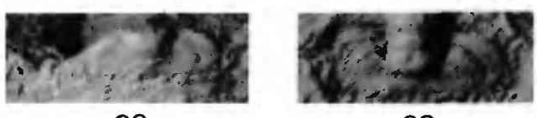

23
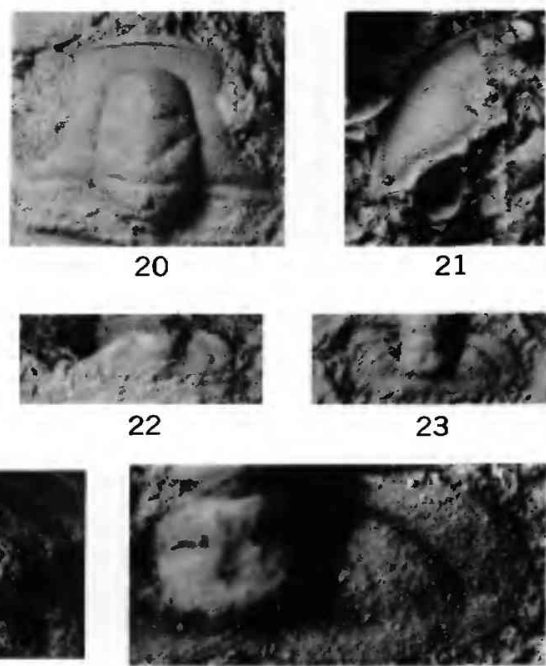

27

ELVINIIDAE AND OLENIDAE 
GEOLOGICAL SURVEY

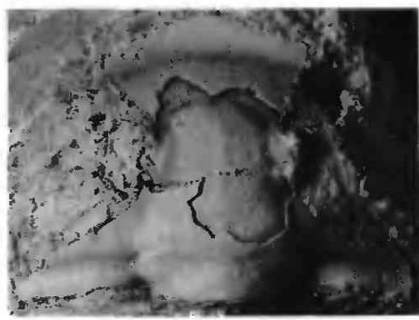

1

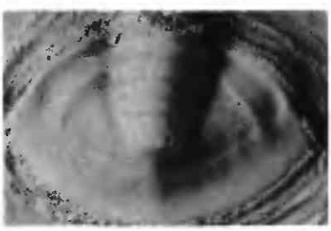

5

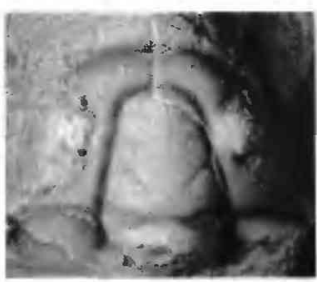

10

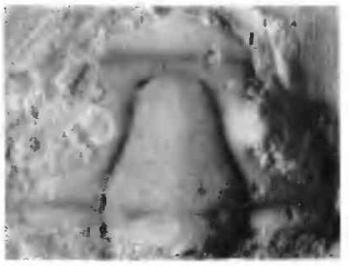

16

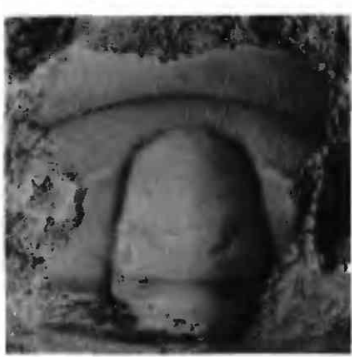

20

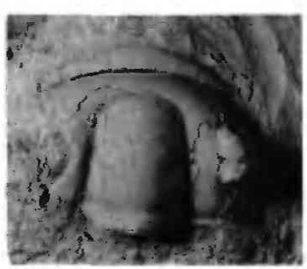

24

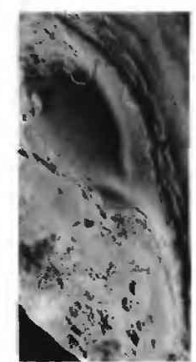

2

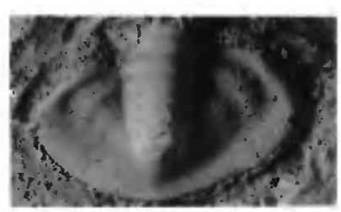

6

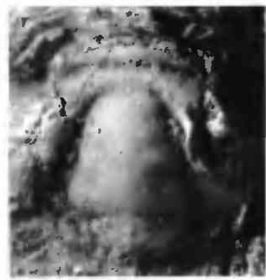

11

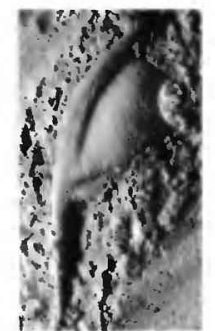

17

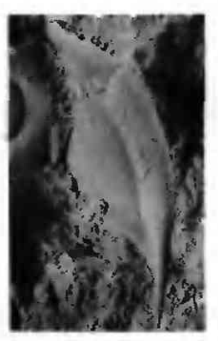

21

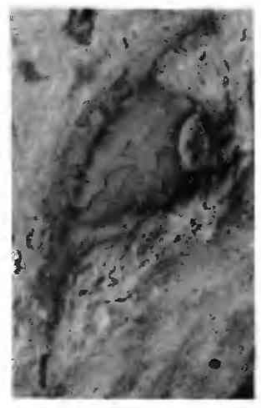

25
PROFESSIONAL PAPER 334 PLATE 7
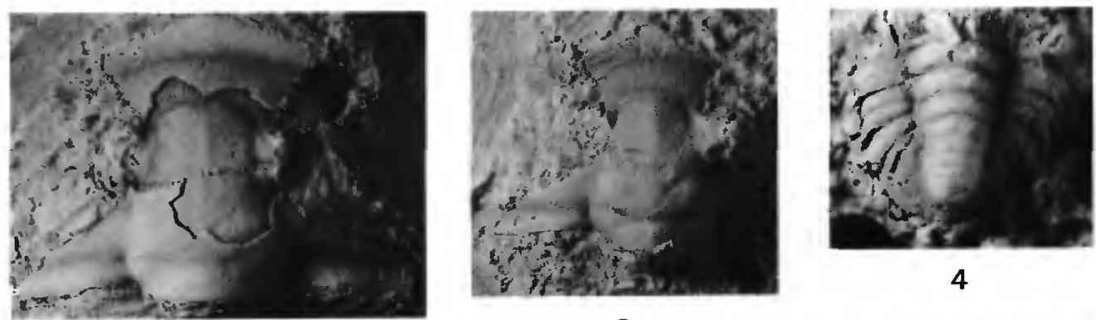

4

3
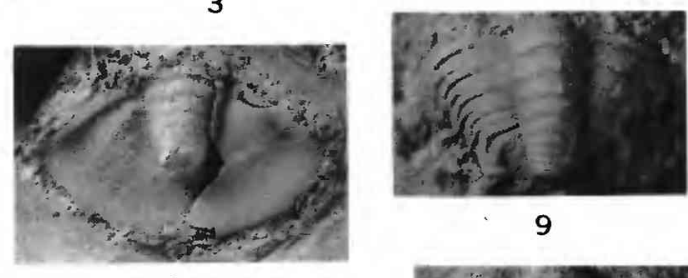

9

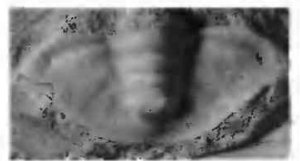

13

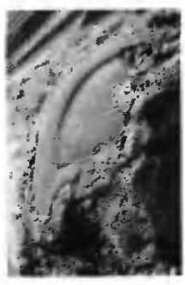

15

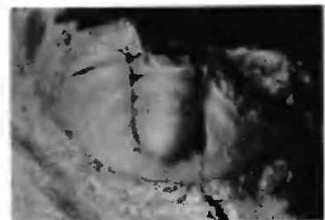

18
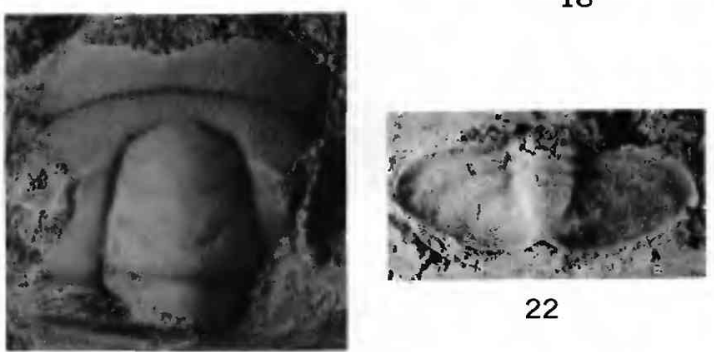

22

14

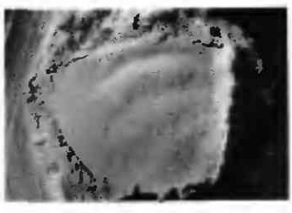

19

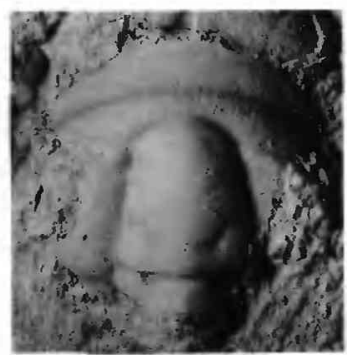

23
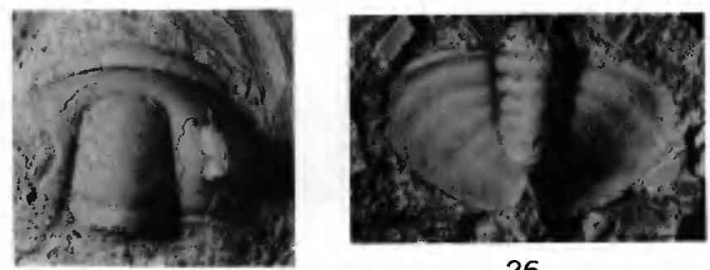

26

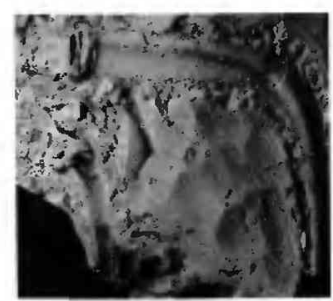

27

HOUSIIDAE AND APHELASPIDINAE 


\section{PLATE 7}

Figures 1-7, 9. Housia ovata n. sp. (p. 75).

1. Stereogram of holotype cranidium, $\times 2$, USNM 136863 , USGS colln. 872-CO.

2. Free cheek, $\times 1$, USNM 136864a, USNM loc. 60 .

3. Cranidium, $\times 4$, for comparison with cranidium of comparable size for Parahousia constriuta $\mathrm{n}$. sp. (fig. 16), USNM 136865a, USGS colln. 955-CO.

4, 9. Transitory pygidia, $\times 15$, USNM 136865 b,c, USGS colln. 955-CO.

5. Exfoliated pygidium, $\times 2$, USNM 136864b, USGS colln. 872-CO.

6. Pygidium showing uneven development of left and right pleural lobes, $\times 3$, USNM 136864c, USGS colln. 872-CO.

7. Pygidium, $\times$ 4, USNM 136865d, USGS colln. 955-CO.

8. Housia halli (Resser) (p. 75), $\times 2$.

Holotype pygidium, USNM 90670, Dunderberg shale, Eureka district, Nevada.

10, 12, 13. Prehousia alata n. gen., n. sp. (p. 78).

10. Stereogram of holotype cranidium, $\times 3$, USNM 136866 .

12. Free cheek, $\times 2$, USNM $136867 \mathrm{a}$.

13. Pygidium, $\times 2$, USNM $136867 \mathrm{~b}$.

All specimens from USGS colln. 1441-CO, Lincoln Peak formation, Snake Range, Nev.

11, 14, 15, 19. Prehousia semicircularis n. gen., n. sp. (p. 78).

11. Holotype, small cranidium, $\times 8$, USNM 136868 .

14. Pygidium showing posterior margin, $\times 3$, USNM 136869 a.

15. Free cheek, $\times 4$, USNM $136869 \mathrm{~b}$.

19. Fragmentary pygidium showing anterolateral margin, $\times 3$, USNM 136869 c.

All specimens from USGS colln. 2294-CO.

16-18. Parahousia constricta n. gen., n. sp. (p. 77), $\times 4$.

16. Stereogram of holotype cranidium, USNM 136870.

17. Free cheek, USNM 136871a.

18. Pygidium, CSNM $136871 \mathrm{~b}$.

All specimens from USGS colln. 955-CO.

20-23. Taenora expansa n. gen., n. sp. (p. 84).

20. Stereogram of holotype cranidium, USNM 136872, USGS colln. 954-CO.

21. Free cheek, $\times 2$, USNM 136873a, USGS colln. 2301-CO.

22. Pygidium, $\times 2$, USNM 136874, USGS colln. 954-CO.

23. Small cranidium, $\times 5$, USNM 136873b, USGS colln. 2301-CO.

24-27. Litocephalus bilobatus (Hall and Whitfield) (p. 82), $\times 2$.

24. Stereogram of cranidium, USNM 128324a.

25. Free cheek, USNM 128324b.

26. Pygidium, USNM 128324d.

27. Thoracic segment, USNM 128324e.

All specimens from USGS colln. 1297-CO. 


\section{PLATE 8}

Figures 1, 3, 5, 8, 11. Cernuolimbus orygmatos n. gen., n. sp. (p. 85).

1. Stereogram of holotype cranidium, $\times 2$, USNM 136875.

3. Pygidium $\times 2$, USNM 136876a.

5. Detail of external surface of right posterior limb of holotype, $\times 10$.

8. Free cheek, $\times 2$, USNM 136876 b.

11. Pygidium, $\times 3$, USNM $136876 \mathrm{c}$.

All from CSGS colln. 2295-CO.

2, 4, 6, 7. Cernuolimbus semigranulosus n. gen., n. sp. (p. 86).

2. Stereogram of holotype cranidium, $\times 3$, USNM 136877.

4. Pygidium, $\times 3$, CSNM 136878a.

6. Detail of external surface of back of glabella of holotype, $\times 10$.

7. Free cheek, USNM 136878b.

All from USGS colln. 2294-CO.

9, 10. Cernuolimbus depressus n. gen., n. sp. (p. 85), $\times 3$.

9. Stereogram of holotype cranidium, USNM 136879.

10. Cranidium, USNM 136880.

Both from LSGS colln. 2297-CO.

12, 13, 15, 16, 19, 20. Litocephalus verruculapeza n. sp. (p. 83).

12. Stereogram of holotype cranidium, $\times 3$, USNM 136881.

13. Detail of cranidial border $\times 3$, USNM 136882a.

15. Free cheek showing shape of anterior part of doublure, $\times 2$, USNM 136882b.

16. Free cheek, $\times 3$, USNM 136882c.

19, 20. Pygidia, $\times$ 3, USNM 136882d, e.

All from USGS colln. 2299-CO.

14, 17, 18, 24. Litocephalus granulomarginatus n. sp. (p. 82).

14. Detail of border of holotype, $\times 5$.

17. Stereogram of holotype cranidium, $\times 2$, USNM 136883, USGS colln. 795-CO.

18. Pygidium, $\times 2$, USNM 136884a, USGS colln. 2300-CO.

24. Free cheek, $\times 2$, CSNM $136884 b$, USGS colln. 2300-CO.

21-23. Anechocephalus trigranulatus n. gen., n. sp. (p. 92), $\times 5$.

21. Pygidium, USNM 136886a.

22. Stereogram of holotype cranidium, USNM 136885.

23. Cranidium, USNM 136886 b.

All from USGS colln. 952-CO. 
GEOLOGICAL SURVEY

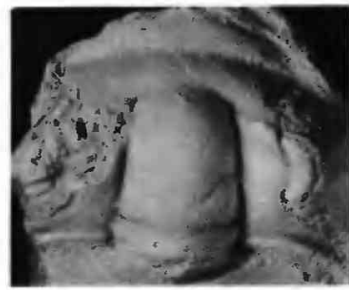

1

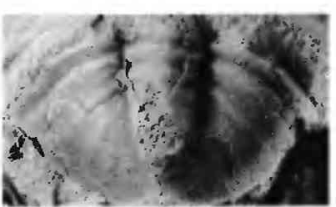

3

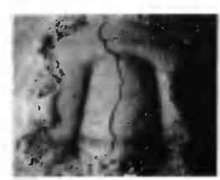

9

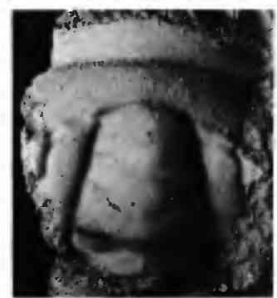

12

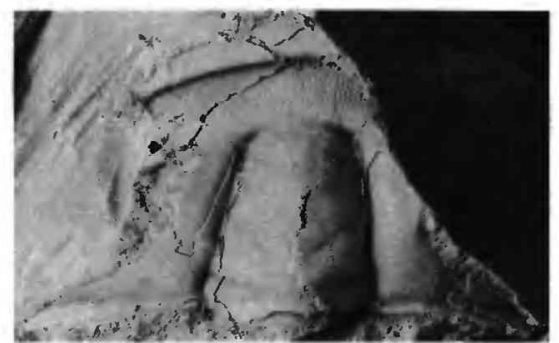

17
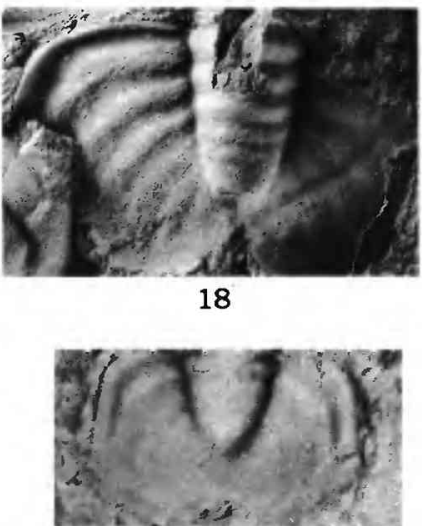

21

2

4

10

13
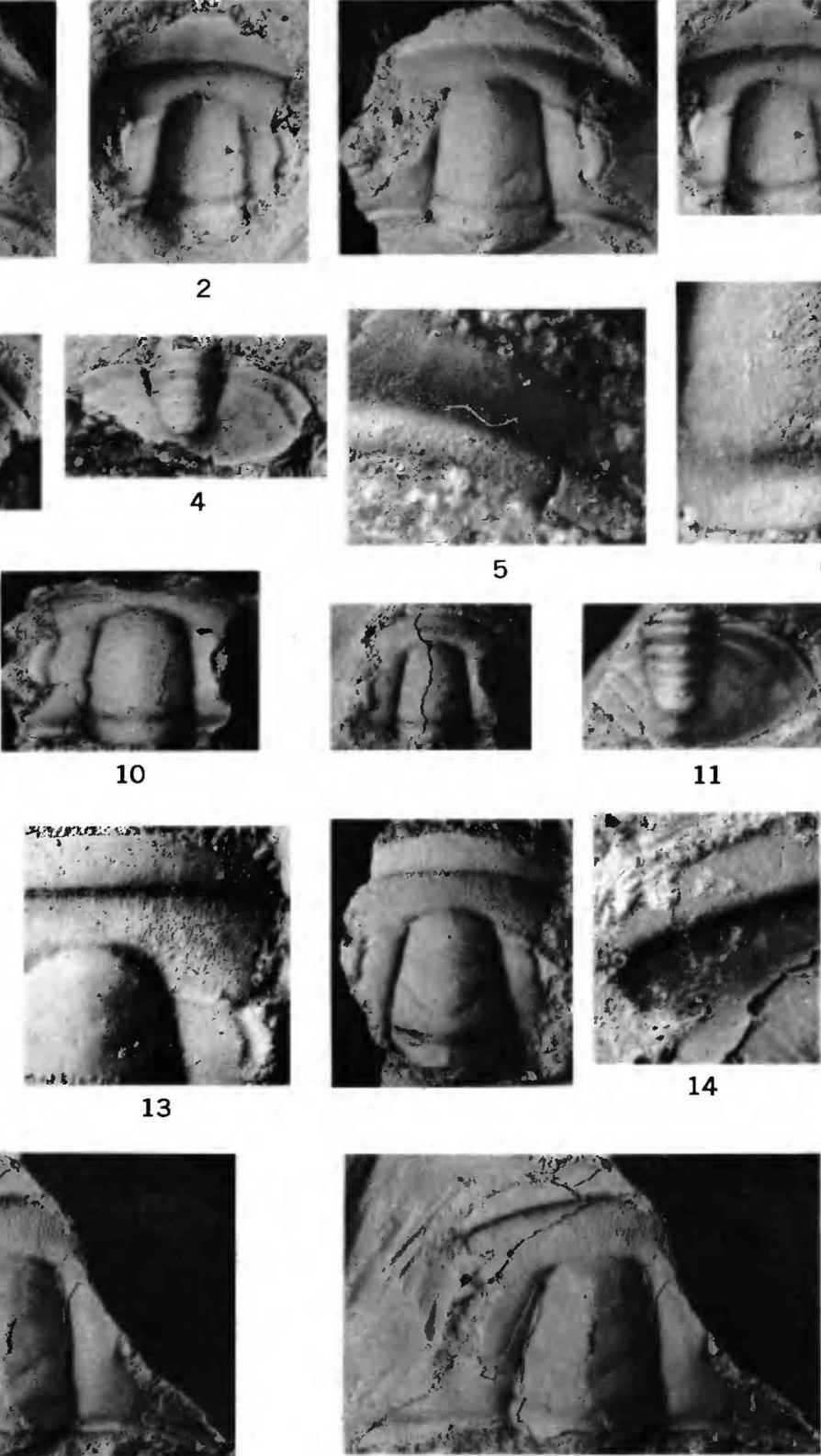

14

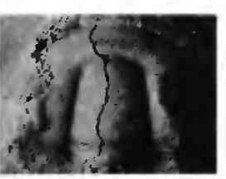

hit ay

11

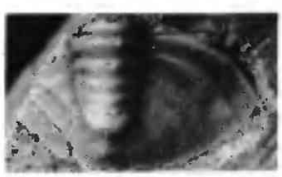

(1)

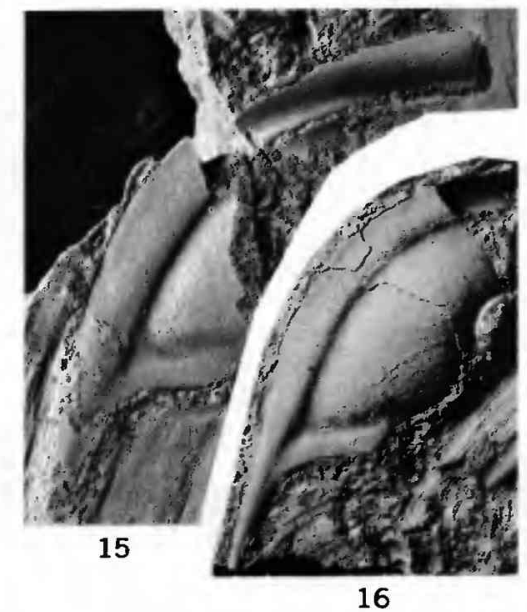

PROFESSIONAL PAPER 334 PLATE 8
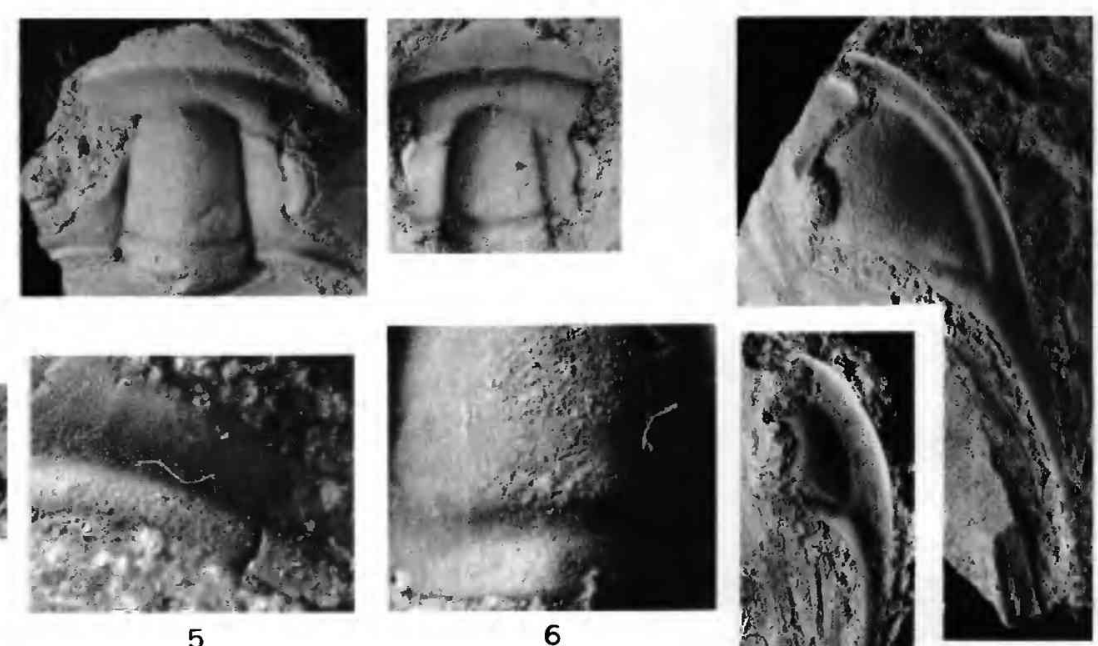

8 
GEOLOGICAL SURVEY

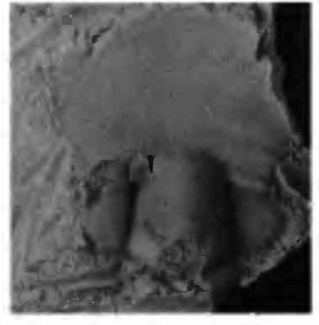

1
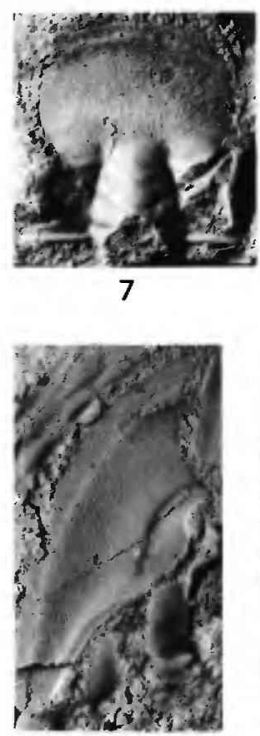

13

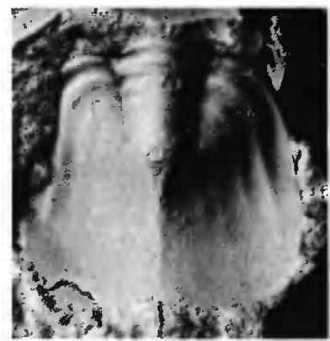

17

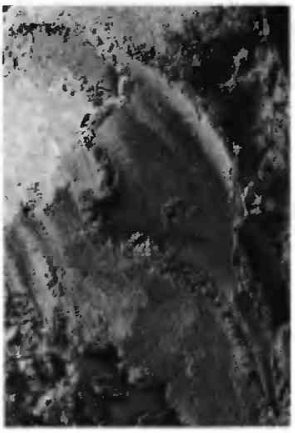

26

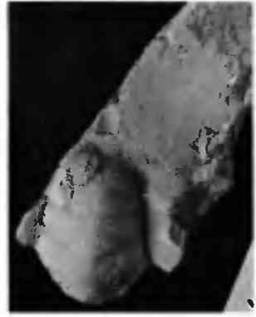

2

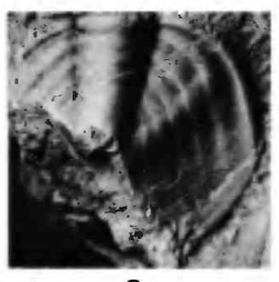

8

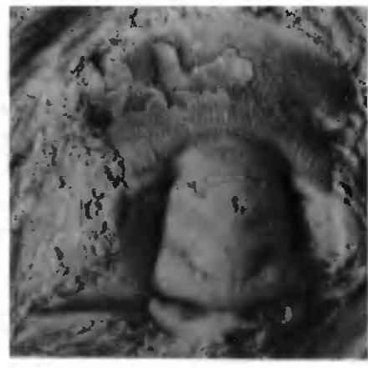

14

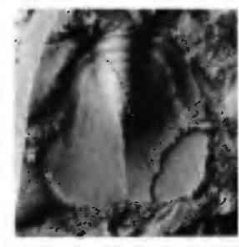

18

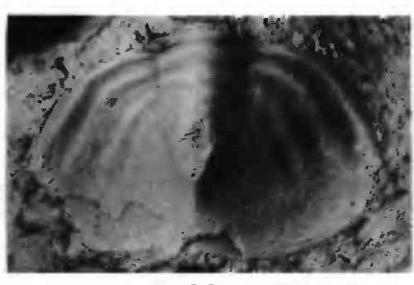

22

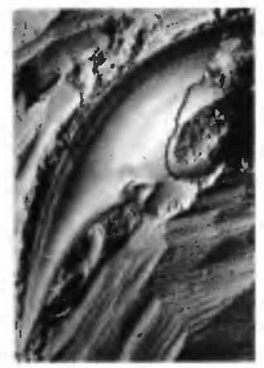

15

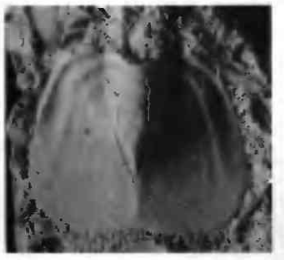

19

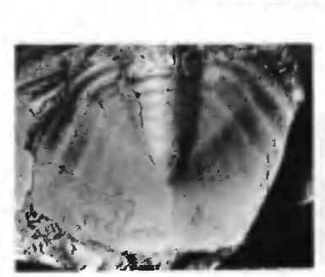

23
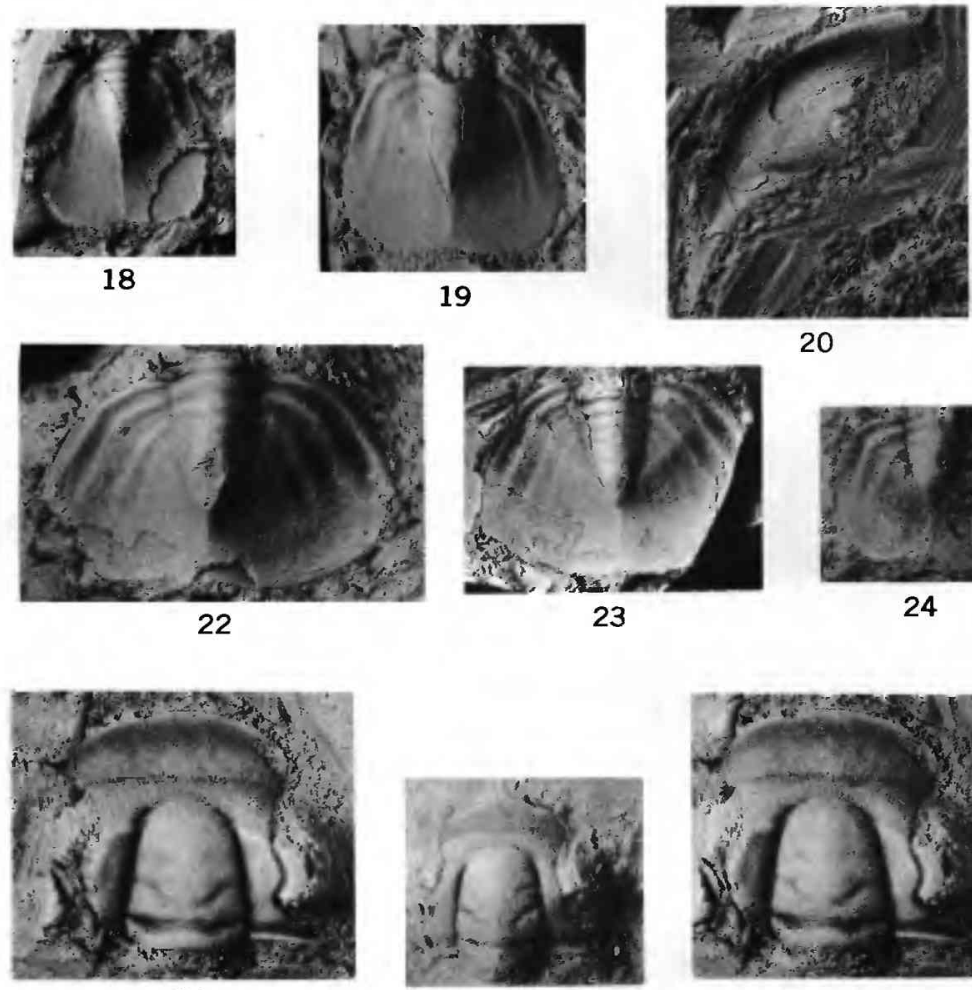

27

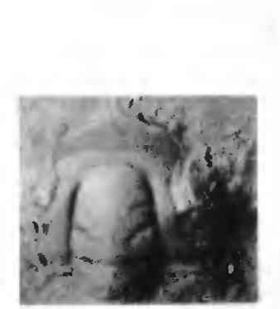

28
20

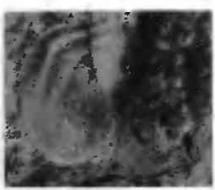

24
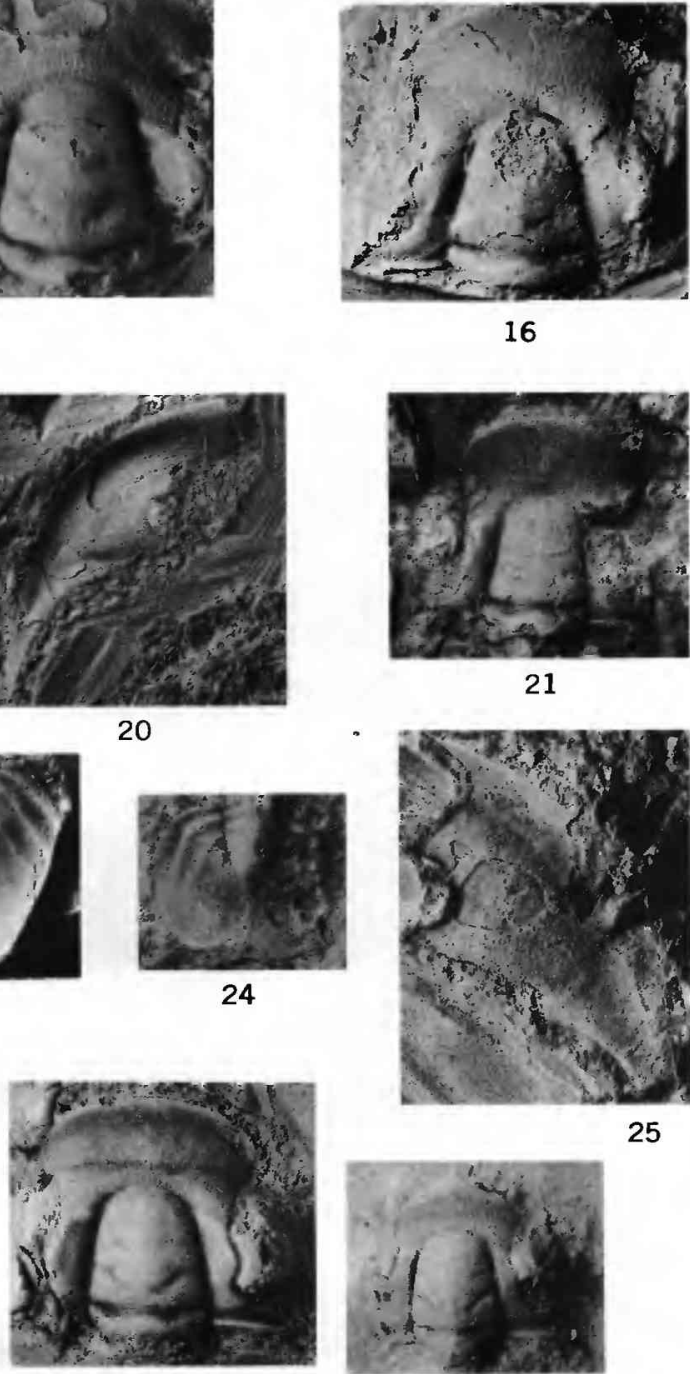

21

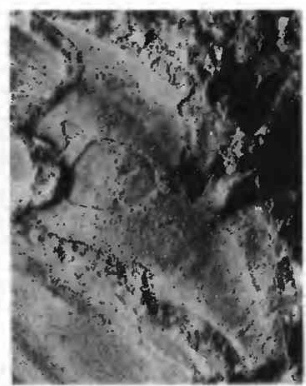

25

PTEROCEPHALIINAE 


\section{PLATE 9}

Figures 1-6, 9-12. Pterocephalia concava n. sp. (p. 88).

1. Stereogram of holotype cranidium, $\times 2$, USNM 136887.

2. Large incomplete cranidium, $\times 1$, USNM 136888a.

3. Medium-sized cranidium, $\times 3$, USNM $136888 \mathrm{~b}$.

4. Small cranidium, $\times 4$, USNM 136888c.

5. Small pygidium, $\times 3$, USNM $136888 \mathrm{~d}$.

6. Free cheek, $\times 1$, USNM 136888 e.

9. Latex cast of large pygidium, $\times 1$, USNM $136888 \mathrm{f}$.

10,11 . Medium-sized pygidia, $\times 2$, USNM $136888 \mathrm{~g}, \mathrm{~h}$.

12. Left pleuron of thoracic segment, $\times 2$, USNM 136888 .

All from USGS colln. 2297-CO.

7, 8, 13. Pterocephalia sanctisabae Roemer (p. 88).

7. Cranidium, $\times 3$, for comparison with comparable-sized cranidium of $P$. concava $n$. sp. (fig. 3), USNM 136889a, USGS colln. 2302-CO.

8. Pygidium, $\times 3$, USNM 136890, USGS colln. 2301-CO.

13. Free cheek, $\times 2$, USNM 136889 b, USGS colln. 2302-CO.

14-20. Pterocephalia elongata n. sp. (p. 88) $\times 3$.

14. Stereogram of holotype cranidium, USNM 136891, USGS colln. 873-CO.

15. Fre cheek, USNM 136893a, USGS colln. 2300-CO.

16. Cranidium, USNM 136893b, USGS colln. 2300-CO.

17. Pygidium, USNM 136892, USGS colln. 873-CO.

18, 19. Pygidia, USNM 136893c, d, USGS colln. 2300-CO.

20. Free cheek showing shape of anterior part of doublure, USNM 136893e, USGS colln. 2300-CO.

21. Pterocephalia occidens (Walcott) (p. 88), $\times 4$.

Holotype cranidium, USNM 24613, USNM loc. 61.

22, 23, 26, 27. Sigmocheilus grata (Resser) (p. 90).

22. Pygidium, $\times 3$, USNM 136894, USGS colln. 952-CO.

23. Pygidium, $\times 3$, USNM 136895a, USGS colln. 2299-CO.

26. Free cheek, $\times 3$, USNM 136895b, USGS colln. 2299-CO.

27. Stereogram of cranidium, $\times 3$, USNM 136895c, USGS colln. 2299-CO.

24, 25, 28. Sigmocheilus utahensis (Resser) (p. 91).

24. Pygidium, $\times 5$, USNM 136896a, USGS colln. 2296-CO.

25. Free cheek, $\times 3$, USNM 136896b, USGS colln. 2296-CO.

28. Stereogram of smali cranidium, $\times 4$, USNM 136897, USGS colln. 795-CO. 


\section{PLATE 10}

Figures 1-3. Sigmocheilus serratus n. gen., n. sp. (p. 91), $\times 3$.

1. Stereogram of holotype cranidium USNM 136898a, USGS colln. 955-CO.

2. Free cheek, USNM 136899, USGS colln. 864-CO.

3. Pygidium, on same block as holotype, USNM 136898b, USGS colln. 955-CO.

4-7. Sigmocheilus pogonipensis (Resser) (p. 91), $\times 3$.

4. Stereogram of characteristic cranidium, USNM 136900a, USGS colln. 2301-CO.

5. Latex cast of pygidium, USNM 136900b, USGS colln. 2301-CO.

6. Cranidium showing shape of anterior margin, USNM 136901, USGS colln. 954-CO.

7. Free cheek, USNM 136900c, USGS colln. 2301-CO.

8. Bynumina globosa (Walcott) (p. 94), $\times 10$.

Stereogram of nearly perfect cranidium, USNM 136902, USNM loc. 61.

9, 10. Bynumiella? acuminata n. sp. (p. 93), $\times 8$.

9. Stereogram of holotype cranidium, USNM 136903.

10. Silicified free cheek, USNM 136904.

Both from USGS colln. 2296-CO.

11, 12. Minupeltis conservator $n$. gen., n. sp. (p. 98), $\times 8$.

11. Stereogram of holotype cranidium, USNM 136905.

12. Assymetrical cranidium with poorly developed right side, USNM 136906.

Both from USGS colln. 2294-CO.

13, 14. Cheilocephalus spp. (p. 94), $\times 3$.

13. Cranidium, USNM 136907, USGS colln. 864-CO.

14. Pygidium, USNM 136908, USGS colln. 2299-CO.

15-17. Morosa longispina n. gen., n. sp. (p. 99), $\times 6$.

15. Stereogram of holotype cranidium, USNM 136909.

16. Pygidium, USNM 136910a.

17. Free cheek, USNM $136910 \mathrm{~b}$.

All from USGS colln. 2299-CO.

18, 21. Pinctus? spp. (p. 101), $\times 10$.

18. Latex cast of cranidium, USNM 136911, USGS colln. 952-CO.

21. Latex cast of cranidium, USNM 136912, USGS colln. 953-CO.

19, 20. Oligometopus breviceps (Walcott) (p. 100), $\times 8$.

19. Stereogram of holotype cranidium, USNM 24577, USNM loc. 62.

20. Cranidium, USNM 136913, USGS colln. 954-CO. 
GEOLOGICAL SURVEY

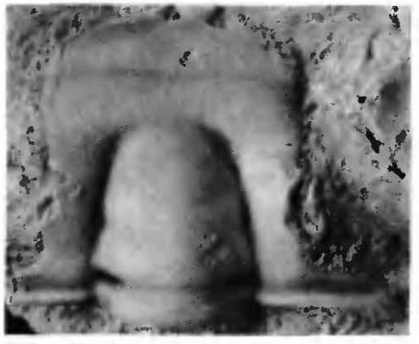

1

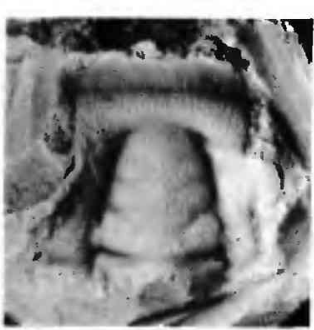

4

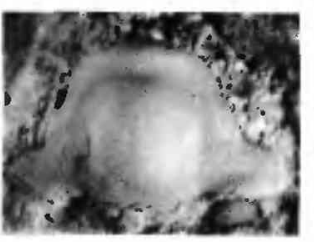

8

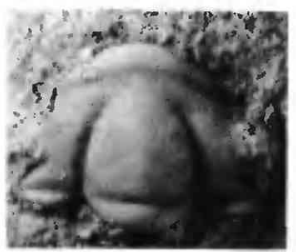

11

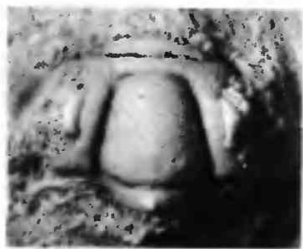

15
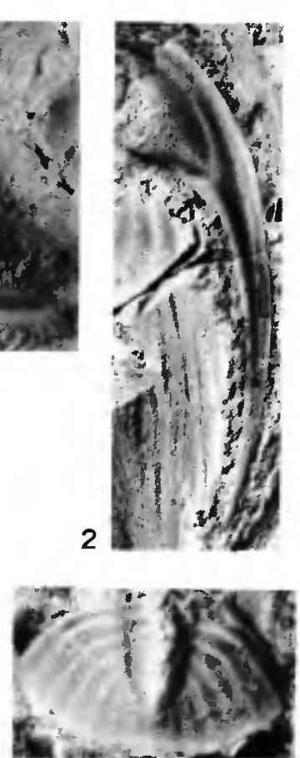

5

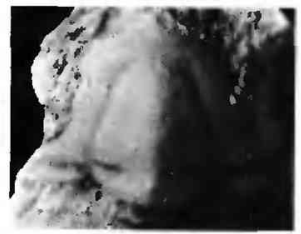

9

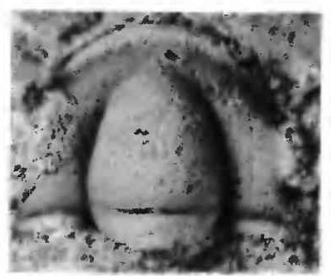

12

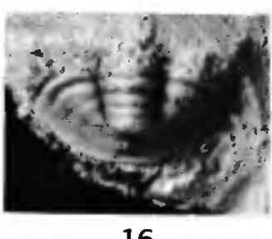

16
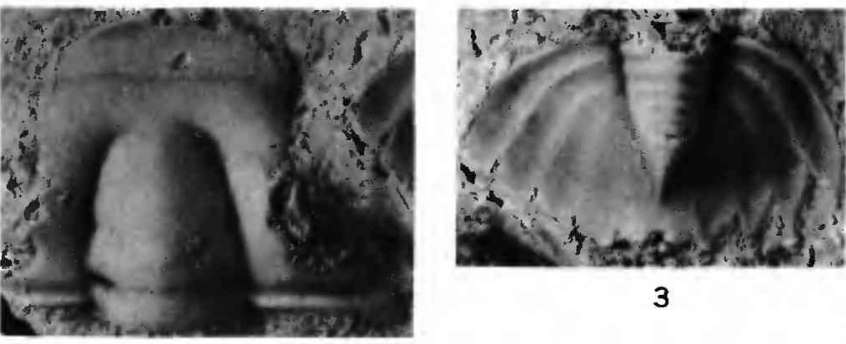

3
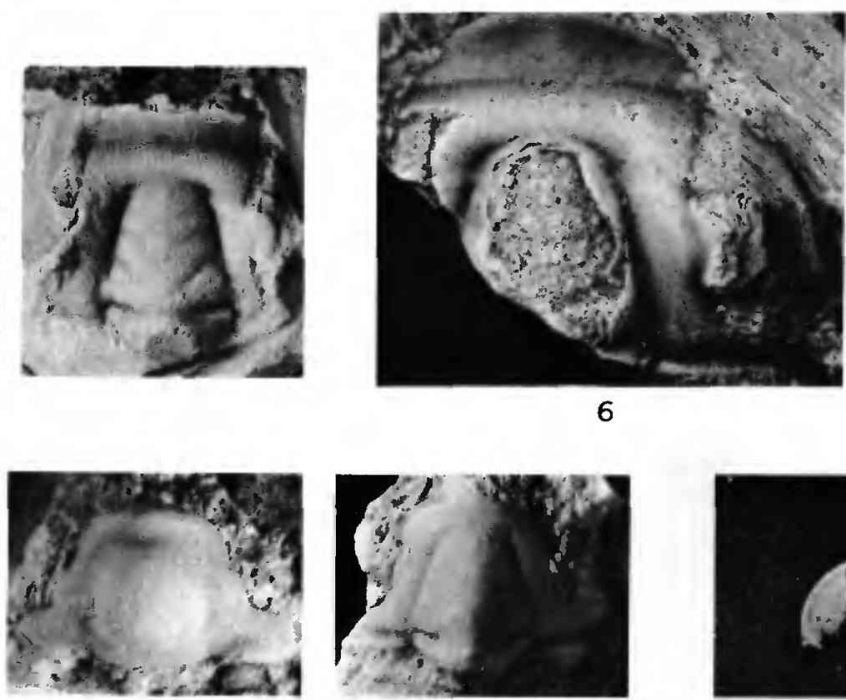

6

10
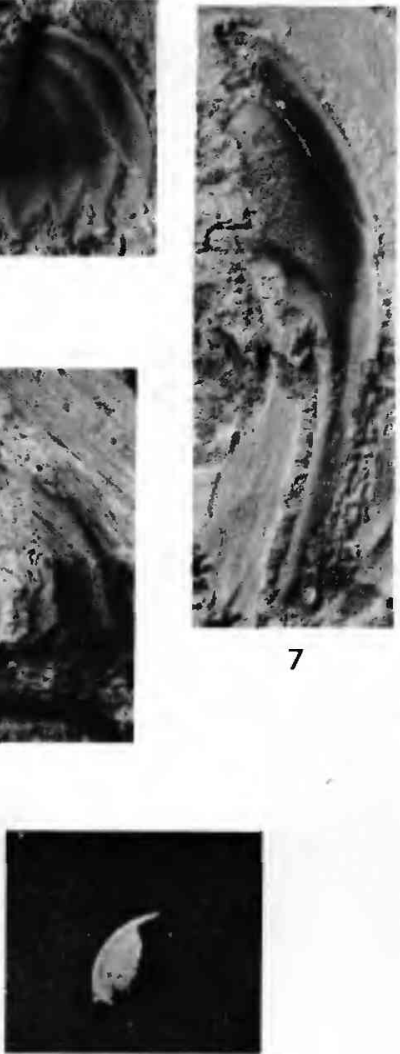
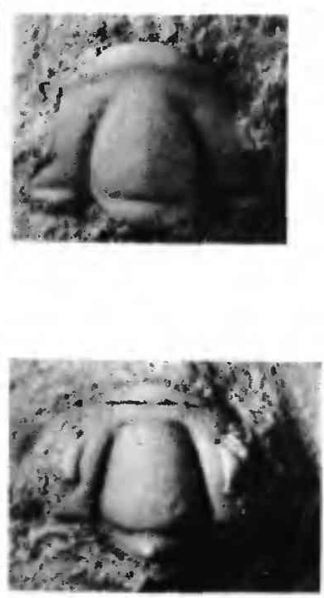

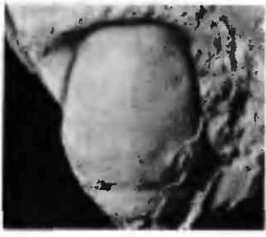

13

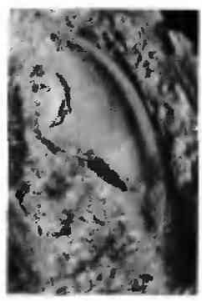

17

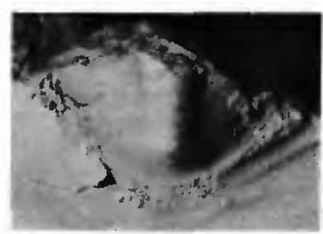

14

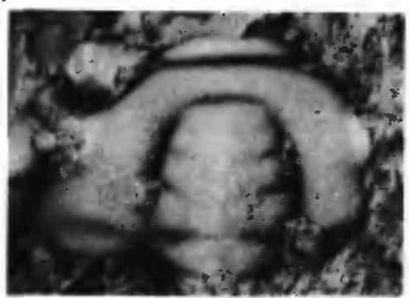

18

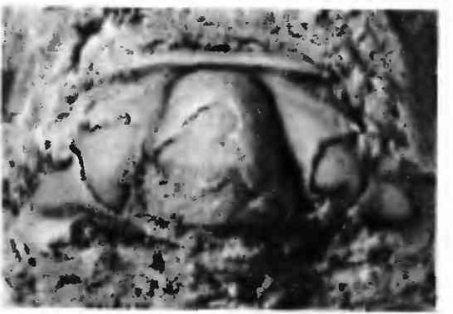

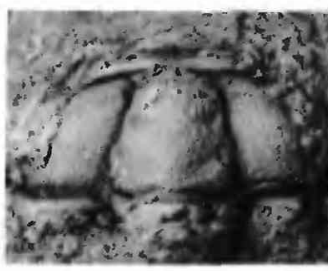

20

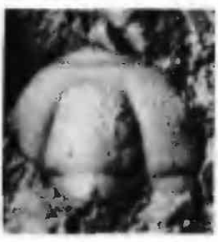

21

PTEROCEPHALIINAE AND UNASSIGNED GENERA 
GEOLOGICAL SURVEY
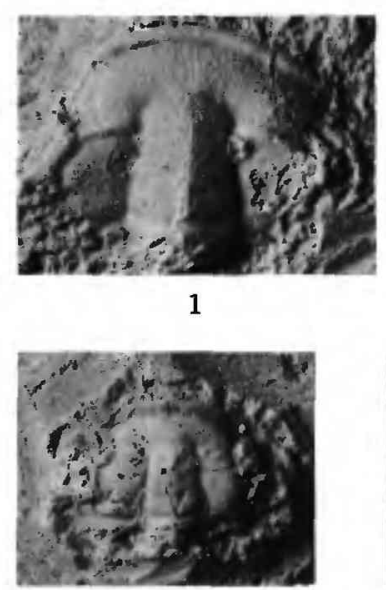

5

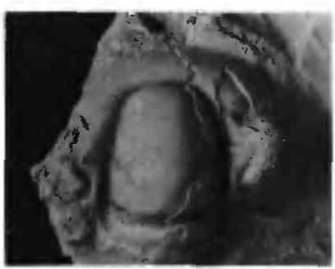

10

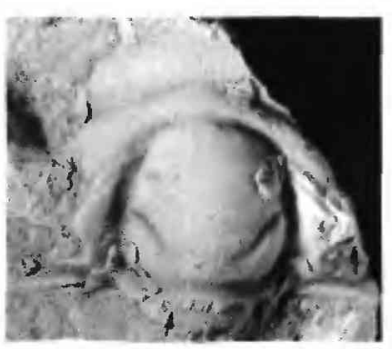

13

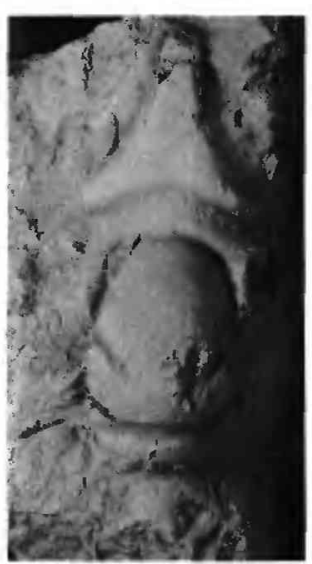

18

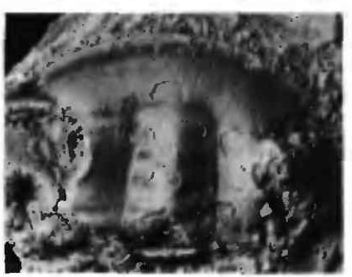

2
3
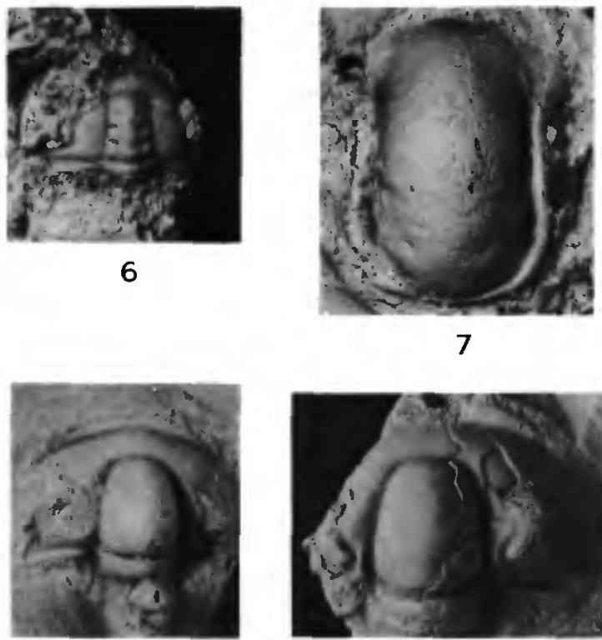

11

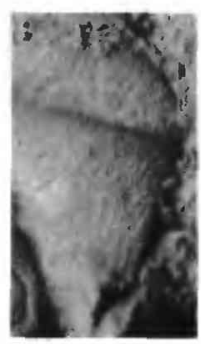

14

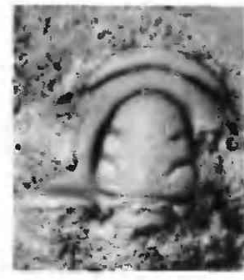

17

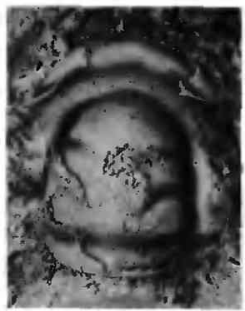

19
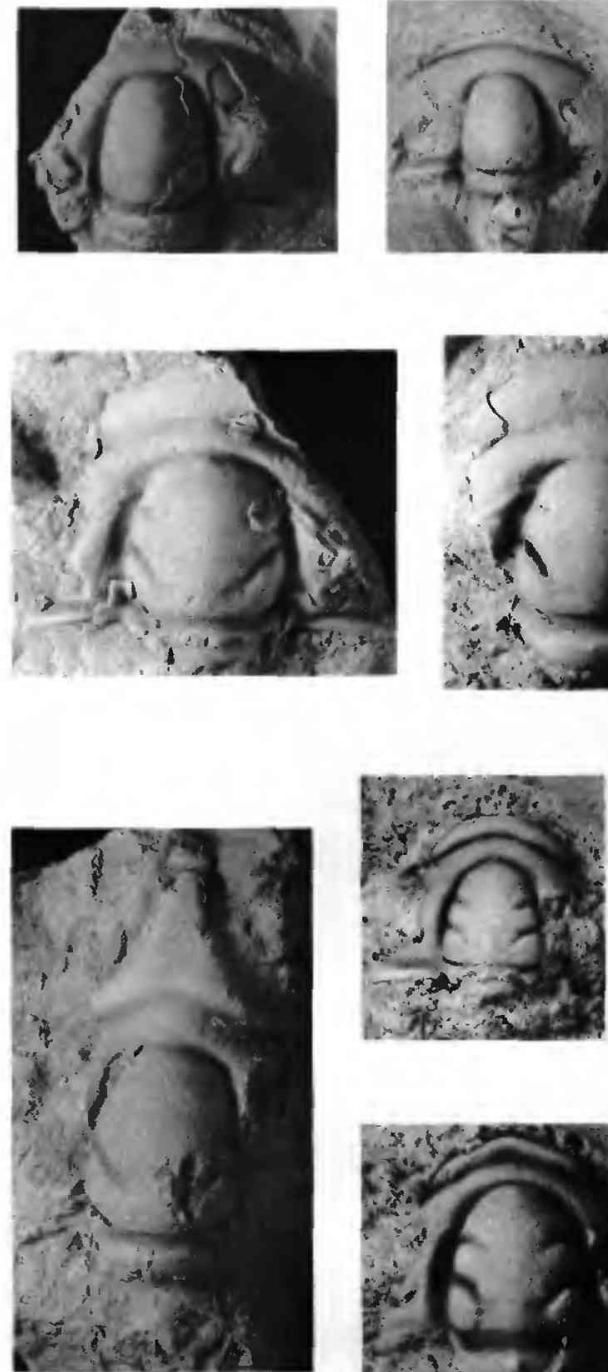

20
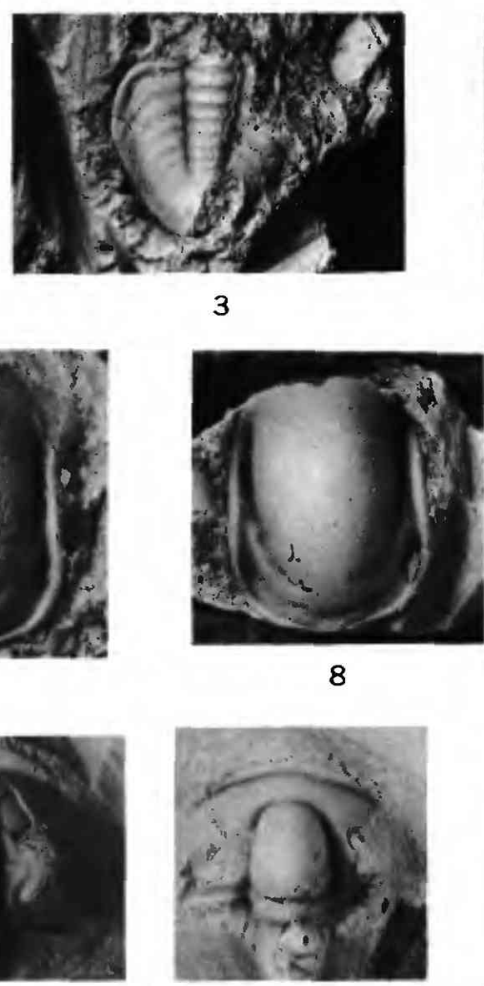

PROFESSIONAL PAPER 334 PLATE 11
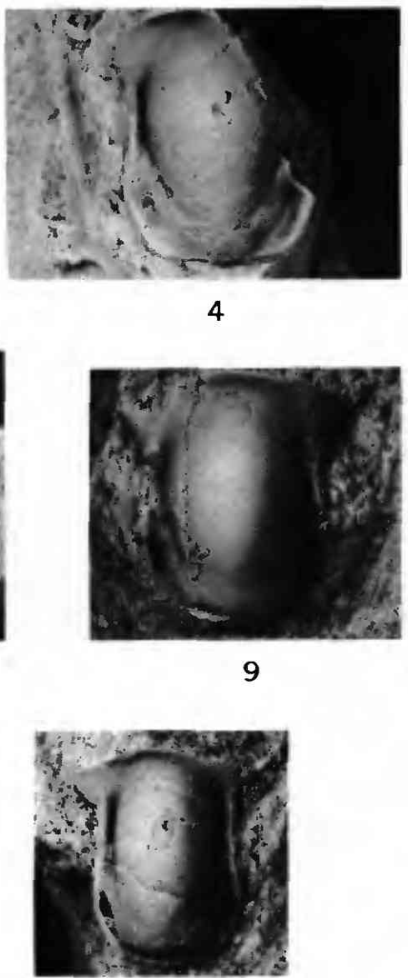

12

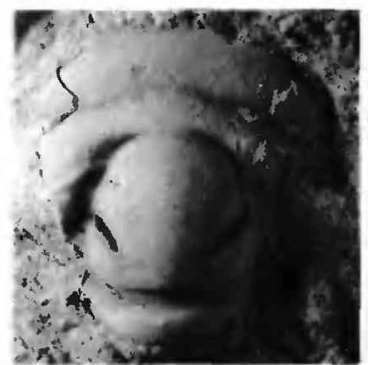

15

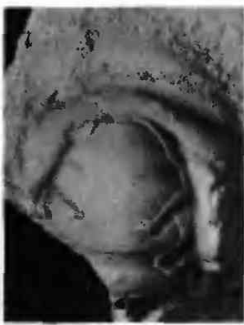

16

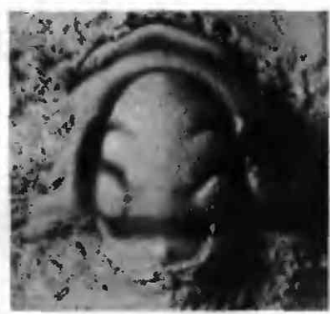

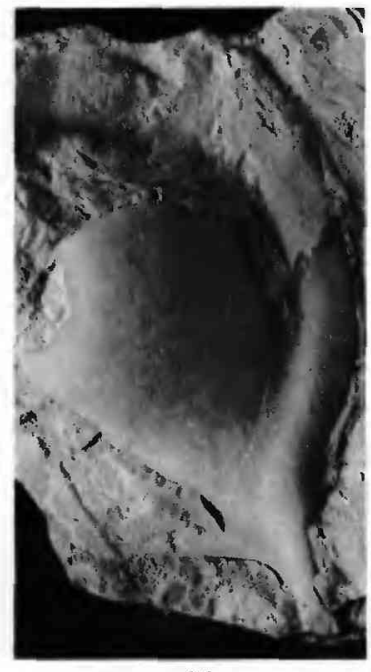

21

UNASSIGNED GENERA AND HYPOSTOMES 


\section{PLATE 11}

Figures 1. Genus and species undetermined 2 (p. 102), $\times 5$.

Cranidium, USNM 136914, USGS colln. 2295-CO.

$2,5,6$. Genus and species undetermined 1 (p. 101), $\times 5$.

2. Cranidium, USNM 136915a.

5. Cranidium questionably assigned to this species, USNM $136915 \mathrm{~b}$.

6. Cranidium, USNM $136915 \mathrm{c}$.

All from USGS colln. 2297-CO

3. Genus and species undetermined 3 (p. 102), $\times 5$.

Pygidium, USNM 136916, USGS colln. 2297-CO.

4, 7-9, 12. Hypostomes (p. 60), $\times 5$.

4. Hypostome, type C, USNM 136917, USGS colln. 2294-CO.

7. Hypostome, type B, USNM 136918, USGS colln. 2295-CO.

8. Hypostome, type E, USNM 136919, USGS colln. 2296-CO.

9. Hypostome, type D, USNM 136920, USGS colln. 2301-CO.

12. Hypostome, type A, USNM 136921, USGS colln. 2302-CO.

10. Pseudosaratogia leptogranulata n. sp. (p. 101), $\times 2$.

Stereogram of holotype cranidium, USNM 136922, USGS colln. 954-CO.

11. Pseudosaratogia abnormis n. sp. (p. 101), $\times 3$.

Stereogram of holotype cranidium, USNM 136923, USGS colln. 955-CO.

13-16. Iddingsia robusta (Walcott) (p. 96).

13. Stereogram of holotype cranidium, $\times 2$, USNM 24609 , USNM loc. 61.

14. Detail of right anterolateral corner of cranidium in fig. $16, \times 5$.

15. Cranidium, holotype of $I$. nevadensis Resser, $\times 2$, USNM 108796, USNM loc. 61 .

16. Cranidium preserving part of external surface, $\times 2$, USNM 136924, USNM loc. 62 .

17, 19, 20. Kindbladia affinis (Walcott) (p. 97).

17. Stereogram of cranidium with external surface preserved, $\times 5$, USNM 136925, USNM loc. 62 .

19. Cranidium, holotype of $K$. nevadensis Resser, $X 4$, USNM 108788a, USNM loc. 61 .

20. Holotype, cranidium, $\rtimes 4$, USNM 24642, USNM loc. 65.

18, 21. Dokimocephalus pernasutus (Walcott) (p. 95), $\times 1$.

18. Holotype cranidium, USNM 24608a.

21. Paratype free cheek, USNM 24608 b.

Both from USNM loc. 61 